NBER WORKING PAPER SERIES

\title{
THE ROLE OF FINANCIAL CONDITIONS IN PORTFOLIO CHOICES: THE CASE OF INSURERS
}

\author{
Shan Ge \\ Michael S. Weisbach \\ Working Paper 25677 \\ http://www.nber.org/papers/w25677
NATIONAL BUREAU OF ECONOMIC RESEARCH
1050 Massachusetts Avenue
Cambridge, MA 02138
March 2019

The authors would like to thank the Risk Institute at the Fisher College of Business, Ohio State University, for supporting this research. We thank Greg Allen, Rui Gong, Hyeik Kim, Yashaswi Mohanty, Jonas Peeters, Botao Wu, and Steven Zheng for excellent research assistance. We thank Jack Bao, Bo Becker, John Campbell, Maria Chaderina, Andra Ghent, Javier Gil-Bazo, Andrei Gonçalves, Zhiguo He, Victoria Ivashina, Ralph Koijen, Holger Mueller, Stijn Van Nieuwerburgh, Marcus Opp, Alexi Savov, Lu Zhang, an anonymous referee, as well as seminar participants at Federal Reserve Bank of Cleveland, University of Utah, University of New South Wales, Australian National University, Ohio State University, New York University, University of Hong Kong, National Taiwan University, Cornell University, Northeastern University, University of North Carolina, Case Western Reserve University, Fixed Income and Financial Institutions Conference, Women Assistant Professors of Finance Conference, Rising Five Star, SFS Cavalcade, and Finance Meets Insurance conferences for helpful discussions. The views expressed herein are those of the authors and do not necessarily reflect the views of the National Bureau of Economic Research.

NBER working papers are circulated for discussion and comment purposes. They have not been peer-reviewed or been subject to the review by the NBER Board of Directors that accompanies official NBER publications.

(C) 2019 by Shan Ge and Michael S. Weisbach. All rights reserved. Short sections of text, not to exceed two paragraphs, may be quoted without explicit permission provided that full credit, including $(\odot$ notice, is given to the source. 
The Role of Financial Conditions in Portfolio Choices: The Case of Insurers

Shan Ge and Michael S. Weisbach

NBER Working Paper No. 25677

March 2019, Revised October 2020

JEL No. G11,G21,G22,G31,G32

\begin{abstract}
$\underline{\text { ABSTRACT }}$
Many institutional investors depend on the returns they generate to fund their operations and liabilities. How do these investors' financial conditions affect the management of their portfolios? We address this issue using the insurance industry because insurers are large investors for which detailed portfolio data are available, and can face financial shocks from exogenous weather events that help us establish causality. Among corporate bonds, for which we can control for regulatory treatment, results suggest that when Property \& Casualty $(\mathrm{P} \& \mathrm{C})$ insurers become more constrained due to operating losses, they shift towards safer bonds. The effect of losses on allocations is likely to be causal since it holds when instrumenting for losses with weather shocks. The change in allocations following losses is larger for smaller or worse-rated insurers and during the financial crisis, suggesting that the shift toward safer securities is driven by concerns about financial flexibility. The results highlight the importance of financial conditions in institutional investors' portfolio decisions.
\end{abstract}

\title{
Shan Ge
}

WWW: shan-ge.com

New York University

44 West 4th Street, 9-81

New York, NY 10012

sge@stern.nyu.edu

Michael S. Weisbach

Department of Finance

Fisher College of Business

Ohio State University

2100 Neil Ave.

Columbus, $\mathrm{OH} 43210$

and NBER

weisbach.2@osu.edu 


\section{Introduction}

Modern portfolio theory began with Markowitz (1952), who proposed the then-novel idea that riskaverse investors will demand a premium to invest in risky assets and the risk of an investor's portfolio will depend on the investor's risk aversion. This idea is naturally applied to portfolios of individual investors, who, according to empirical evidence, do in fact tend to be risk-averse. However, in contrast to the era in which Markowitz wrote his seminal work, the vast majority of financial assets today are owned or managed by institutional investors rather than individuals. The largest investors in the economy today, institutional investors such as pension funds, endowments, and insurance companies, are organizations that depend on their financial investments to fund their operations. Since these organizations do not necessarily have "preferences" like individual investors, it is not obvious how one would characterize the way they view the tradeoff between risk and return. What drives their portfolio choices? How should we characterize these institutional investors’ portfolio optimization problem?

The answers to these questions are of fundamental importance to our understanding of financial markets. Endowments, foundations, pension funds, and insurance companies had U.S. assets of over \$22 trillion at the end of 2017. ${ }^{1}$ Their portfolio choices could materially impact the price of risk in the economy, and their appetite for different securities can affect different firms' cost of capital differently. These investors differ from professionally managed portfolios such as mutual funds and hedge funds because these investors rely at least partially on the returns from their investments to fund their operations. Consequently, the issues raised in the corporate finance literature on risk and liquidity management are likely to help characterize the way in which these investors manage their financial portfolios.

\footnotetext{
${ }^{1}$ At the end of 2017, insurers hold invested assets worth $\$ 6.5$ trillion and pension funds hold $\$ 14.5$ trillion. At the end of 2015, university endowments hold $\$ 0.5$ trillion, and foundations hold $\$ 0.9$ trillion. The sources for these figures are: National Association of Insurance Commissioners for insurers (www.naic.org/capital_markets_archive/180816.pdf), Federal Reserve Statistical Release, Financial Accounts of the United States for pension funds (www.federalreserve.gov/releases/z1/20180920/z1.pdf, page 94), Department of Education for university endowments (nces.ed.gov/fastfacts/display.asp?id=73), and Foundation Center for foundations (data.foundationcenter.org/).
} 
If an institutional investor relies on returns from its financial investments to fund operations, it will have to account for the possibility that the organization has a cash shortfall, and will need to sell some of its investments. If an institution's investments are highly illiquid, it will have a harder time meeting these increased liquidity demands. This illiquidity will be more of a problem for firms who face a higher cost of external financing, which could lead more financially constrained institutions to prefer a more liquid portfolio. $^{2}$ In addition, liabilities can increase, leading the organization closer to insolvency. For example, a pension fund's liabilities and its probability of insolvency can increase if retirees' life expectancy increases. If an institution invests in risky assets whose value declines with high probability, the institution will be more likely to approach costly bankruptcy. For this reason, more constrained institutions could prefer a safer portfolio. ${ }^{3}$ It is also possible that agents managing these portfolios become more risk-averse as the probability of losing their job due to institutions' insolvency increases, which is a cost coming from a firm's weak financial conditions. This possibility would also lead financial constraints to move institutions' portfolios toward safer and more liquid securities. Alternatively, worse financial conditions could lead institutions to shift toward riskier and more illiquid securities as institutions gamble for higher returns as famously suggested by Jensen and Meckling (1976).

We evaluate the portfolio decisions of a sample of 2,926 U.S. insurers between 2001 and 2015. Insurers are important institutional investors, holding \$6.5 trillion of financial assets in 2017, including more than $25 \%$ of U.S. corporate bonds. Insurers report detailed security-level holdings, so we can observe the risk and liquidity of these investments. In addition, P\&C insurers can suffer from shocks due to unusual weather events, like hurricanes, which can meaningfully worsen insurers’ financial conditions by increasing their demand for cash and their probability of insolvency. These exogenous shocks presumably occur

\footnotetext{
${ }^{2}$ The idea that concerns about future financial constraints can affect liquidity management policies dates at least to Keynes (1936). The modern literature examining this idea began with Opler, Pinkowitz, Stulz, and Williamson (1999). See Almeida, Campello, Cunha, and Weisbach (2014) for a survey.

${ }^{3}$ The argument that the demand for risk management comes from the cost of accessing external financial markets was proposed by Froot, Scharfstein, and Stein (1993).
} 
independently of insurers' financial investments, and help us identify the causal effects of insurers' financial conditions on their portfolios.

We first present some stylized facts about how insurers’ portfolios vary cross-sectionally with insurers' characteristics. Larger insurers have substantially different portfolios than smaller insurers. In particular, larger insurers have, as a fraction of their total portfolio, less cash and government debt, but more mortgage-backed securities (MBS) and corporate bonds. This pattern is consistent with the idea that larger insurers have smaller exposure to risks from operations due to the diversification in their underwriting business. Lower exposure to operational risk means that larger insurers can take on more risk in their financial portfolios. Alternatively, it could be that larger insurers are less financially constrained, leading them to hold riskier and less liquid financial portfolios.

Securities differ from one another in a number of dimensions. Cash and government debt are safer, more liquid, and also receive more lenient regulatory treatment than MBS and corporate bonds. (Section 2 discusses the regulatory treatment of insurers' financial security holdings in detail.) To evaluate whether insurers' financial conditions affect their choice between safer and riskier, as well as between more liquid and less liquid securities, we focus on insurers' holdings of corporate bonds, because we can control for regulatory treatments among corporate bonds.

As a more direct way of linking financial conditions with insurers' portfolios, we assume that insurers' operating losses represent negative shocks to their financial conditions and estimate the way that portfolios change following operating losses. To address the concern that insurers' operating losses and portfolio choices could both be related to their unobservable characteristics (e.g. management quality), we construct an instrumental variable for P\&C insurers' losses with two sources of data: unusual weather damages at the state-quarter level and insurers' lagged market share in each state. The instrument is constructed to reflect insurers' exposure to unexpected weather shocks.

Our results suggest that following operating losses, $\mathrm{P} \& \mathrm{C}$ insurers reduce their holdings of riskier corporate bonds, holding constant the regulatory treatment of different bonds. This finding also holds when instrumenting for losses using weather data. We also find that following operating losses, insurers are more 
likely to purchase bonds that are relatively safer and more liquid. The effect of losses on the shift towards safer bonds in insurers' holdings lasts around seven quarters. In addition, we find that when firms are smaller or worse-rated and during the 2008 Financial Crisis, operating losses lead insurers to have larger increases in the allocation to safer bonds. Firms' financial conditions are likely to be affected more by unexpected losses if they are smaller or worse-rated, and during the 2008 Financial Crisis. Therefore, this result provides additional support for the view that when financial constraints are exacerbated, insurers shift their portfolios toward safer and more liquid securities.

Since insurers are regulated, the observed change in portfolios following losses could potentially occur because of regulatory pressure. In our estimates using insurers' corporate bond holdings, we essentially compare bonds with the same regulatory treatment in terms of risk-based capital charge. It is possible, though, that regulators, through other rules and actions, effectively force insurers to shift towards safer portfolios following operating losses. However, inconsistent with this idea, we find that insurers closer to the regulatory lower bound for capital ratio do not tend to shift towards safer bonds more after losses than insurers further away from the lower bound. Given that insurers closer to the regulatory lower bound are more likely to receive regulators' scrutiny, this result suggests that insurers' shift towards safer bonds is unlikely merely driven by regulators' intervention.

We also find that even when insurers' capital ratios are below the regulatory lower bound, they still purchase bonds rated below A-. Thus, insurers unlikely face restrictions on their investment in bonds rated A- or better. Our results still hold when we restrict to bonds rated A- or better, where insurers are unlikely to face regulatory restrictions. We also conduct robustness test restricting our analysis to insurers that purchase bonds rated worse than A- and study their investment in bonds rated A- or better in the same quarter. It is unlikely that regulators restrict insurers' choices among bonds rated A- or better when insurers are allowed to purchase bonds rated worse than A-. Our results on how losses affect insurers' corporate bond portfolios hold. Overall, the evidence suggests that insurers' shift towards safer bonds following losses occurs at least partially because of voluntary choices, and is not just a consequence of regulatory pressure. 
In addition to our findings about the way in which financial conditions affect portfolio allocations, this paper has three other important implications. First, we provide insights on insurers' attitudes toward risk, and their desired portfolio if they were not financially constrained. We find evidence consistent with the idea that insurers in better financial conditions have larger portfolio weights on riskier and more illiquid securities. Consequently, in the absence of concerns about financial constraints, insurers appear to seek higher expected returns by taking on more risk and illiquidity in their financial portfolio. If seeking higher expected returns is the objective of these investors absent concerns about financial constraints, one cost of insurers' financial constraints is that insurers need to forego higher expected returns in exchange for lower risk and more liquidity in their financial portfolio.

Second, this paper also offers micro-level evidence that institutions’ financial conditions are likely among the drivers of the "flight to quality" phenomenon, meaning that during market downturns, their demand for securities shifts more toward safer ones. ${ }^{4}$ We find that insurers in weaker financial conditions have larger portfolio weights in safer assets, more so during the financial crisis. Erel et al. (2012) document that during market downturns, low-rated firms issue substantially fewer bonds, but high-rated firms issue more bonds than in good times. Our paper finds that for insurers, who hold more than one-quarter of all the corporate bonds in the U.S., exogenous shocks to financial conditions lead them to shift their portfolios towards safer assets. If similar shifts in demand for securities occur when aggregate downturns worsen insurers' financial constraints, then the aggregate shift towards issuances of safer bonds during worse financial conditions can be partially explained by the shifting demand for safer bonds.

Third, this paper presents a test of theories about the way in which firms respond to negative shocks to their financial condition. The “risk-management” theories of Smith and Stulz (1985), Froot, Scharfstein and Stein (1993), and Almeida, Campello, and Weisbach (2011) imply that a weakening of a firm's financial condition should lead to a reduction of the risk of the firm's portfolio because of the increased cost of raising capital in the event of a financial shortfall. In contrast, the "risk-shifting” argument of Jensen and Meckling

\footnotetext{
${ }^{4}$ See, for example, Caballero and Krishnamurthy (2008) and Vayanos (2004) for theoretical motivation of the flight to quality arguments.
} 
(1976) suggests that a weakening of a firm's financial conditions should instead lead it to increase the riskiness of its portfolio. Our results support the idea that the risk-management incentives increase as firms' financial conditions worsen, since we find that insurers shift towards safer financial investments in response to a negative financial shock. However, insurers are regulated entities. Even though our results suggest that insurers' tendency to shift their portfolios towards safer securities following shocks is at least partially due to their voluntary choice, it is entirely possible that other firms and institutional investors behave differently.

This paper is closely related to the literature on intermediary asset pricing (e.g. He and Krishnamurthy (2012, 2013 and 2018)). In these models, when asset values decline, a reduction in the risk tolerance of the managers of the intermediary leads them to alter the intermediary's portfolio. Our evidence suggests that the phenomenon He and Krishnamurthy describe is widespread — when asset values decline and financial constraints tighten, institutional investors shift their portfolios toward safer securities. This study also relates to papers on investors' heterogeneous demand for financial assets, e.g. Koijen and Yogo (2019). We shed light on one of the factors that can affect institutional investors' demand for different assets, namely the institutions' financial conditions.

We also contribute to the literature on whether financial constraints increase risk-management or risk-shifting behavior in asset holdings. Rauh (2009) suggests that defined benefit pension plans hold a larger portion of safer assets such as government debt and cash when the plans are poorly funded or the firms have poor credit ratings. Duchin et al (2017) find that nonfinancial firms have larger portfolio weights in safer assets if they are more financially constrained. Our results are consistent with these two studies, using a different set of firms, insurers, who have large portfolios and are important actors in the economy. We improve upon these two papers in two ways. First, we identify the causal effect of firms' financial conditions on their portfolio choices by using weather shocks to insurers' operations. Second, since we have CUSIPlevel data on insurers' financial assets, we can better control for the securities' liquidity while studying how securities' riskiness affects insurers' allocation to them by examining the allocation within an asset class. 
Moreover, the tradeoffs between return and risk/liquidity across asset classes studied by Rauh (2009) and Duchin et al (2017) are different from the tradeoffs within asset classes that we focus on. ${ }^{5}$

One other related paper is Becker and Ivashina (2015), which documents that insurers reduce their reaching-for-yield in their bond portfolios during the 2008 Financial Crisis. This finding is consistent with our result that insurers reduce the risk of their portfolios when they are more constrained. Some other papers also study insurers' investment in financial assets, some of which focus on how regulation affects insurers' holdings and some others focus on the effect of insurers' holdings (or transactions) on the underlying assets. ${ }^{6}$ Our paper is distinct in studying the causal effect of insurers' financial conditions on the riskiness of bonds they hold using plausibly exogenous shocks to insurers’ financial health.

\section{Relevant Regulation}

Regulators monitor insurers' financial health using a number of different measures. An important one is the Risk-Based Capital ratio (hereafter RBC ratio). This ratio can be seen as the book value of equity

\footnotetext{
${ }^{5}$ Cortés and Strahan (2017) and Schüwer, Lambert, and Noth (2019) study how banks respond to natural disaster shocks both in their operations and their asset holdings. Mohan and Zhang (2014), and Andonov, Bauer and Cremers (2017) find that public pension funds have higher portfolio weights on riskier assets if the funds have a severe underfunding problem. Some other papers examine firms' real investments. Andrade and Kaplan (1998) and Gilje (2016) do not find evidence for risk-shifting behavior. Calomiris and Wilson (2004) and Duchin and Sosyura (2014) suggest more constrained banks engage in less risky activities. Using numerical techniques, Parrino and Weisbach (1999) estimate the magnitude of the investment distortions due to stockholder-bondholder conflicts, which they conclude to be small for most firms. However, some papers do find evidence for risk-shifting incentives, for example, Hovakimian and Kane (2000), Eisdorfer (2008), Rampini, Sufi and Viswanathan (2014), Landier, Sraer and Thesmar (2015), Acharya and Steffen (2015), and. Drechsler et al (2016).

${ }^{6}$ Ambrose, Cai, and Helwege (2008), Ellul, Jotikasthira, and Lundblad (2011) and Merrill et al (2014) study insurers' sales of downgraded assets. Becker, Opp, and Saidi (2020) study how changes in regulation distort insurers' holdings of MBS. Ellul et al (2015) examine how different accounting rules affect insurers' asset holdings differently during the crisis. Kirti (2017) examines how insurers hit hard during the crisis adjust their portfolio holdings. Chen et al (2020) study how insurers' operating risk affect their portfolio choices. Sen (2018) studies how regulation affects life insurers' hedging incentives. Chodorow-Reich, Ghent, and Haddad (2018) argue that life insurers can insulate the value of financial assets from exposure to market movement by holding the assets for the long run. Getmansky et al (2016) and Nanda, Wu, and Zhou (2019) study the commonality in insurers' portfolio and its effect. Ellul et al (2018) find that the investment of insurers selling variable annuities can create systemic risk. Murray and Nikolova (2018) argue that insurers' portfolio choices, driven by regulation, affect prices of corporate bonds. Huang et al (2018) and Chaderina, Muermann, and Scheuch (2018) study the effect of insurers' holdings (and selling) of illiquid (liquid) bonds affect the bond pricing. Greenwood and Vissing-Jorgensen (2018) document how pension and insurance assets affect the yield curve. Massa and Zhang (2020) study the effect of insurers' selling of bonds following Katrina on bond issuers' financing choices. Chen, Kamiya, and Lou (2019) study how insurers' financial health affect municipal bond liquidity risk they hold.
} 
(more precisely, in the language of the regulation, total adjusted capital) divided by the required capital. Regulators have complex formulas for calculating the denominator, the required capital. Financial securities in insurers' portfolios can add to the required capital. The addition to required capital can be simplified as a percentage of the book value of the security, which we denote as Risk charge ${ }^{*} B V$ of the security, where $B V$ stands for the book value of the security. The way in which a particular security can affect insurers' RBC ratio can be approximated with the following formula:

$$
R B C \text { Ratio }=\frac{\text { Equity excluding the security }+B V \text { of the security }}{\text { Required capital excluding the security }+ \text { Risk charge } * B V \text { of the security }}
$$

The Risk charge for a particular security differs across securities. Table 1 summarizes these risk charges. Generally, the riskier a security is, the larger is the risk charge. For example, the risk charge is 0 for treasury securities, $0.96 \%$ for corporate bonds rated BBB, and $7.38 \%$ for corporate bonds rated B.

\section{Data}

\subsection{Insurers’ Financial Data and Security Holdings in Categories}

We obtain financial data for 2,084 P\&C and 842 U.S. life insurers between 1999 and 2015 from the National Association of Insurance Commissioners (NAIC) and SNL Financial. Insurers’ financial strength ratings are from Best’s Insurance Reports by A.M. Best between 2004 and 2013. A.M. Best is the leading rating agency for insurance companies, and issues such reports three times a year. We transform insurers' A.M. Best ratings to integers starting from one, with larger numbers indicating worse ratings. Insurers with negative assets or net premium written lower than $\$ 10,000$ are excluded. All financial variables, except ratings, are winsorized at the 1st and 99th percentiles. Panel A of Table 2 offers summary statistics on insurers’ financials.

To study the effect of insurers' financial conditions on their portfolios, we use P\&C insurers' operating losses due to insurers' underwriting activities as shocks that worsen their financial constraints. We set underwriting losses, Loss, as the absolute value of net underwriting gain scaled by lagged assets if net 
underwriting gain is negative, and zero otherwise. Loss is either positive, indicating poor underwriting performance, or zero. The net underwriting gain, and thus also Loss, is net of reinsurance payments.

We also construct an instrumental variable for the reported P\&C insurers' underwriting losses, following Ge (2020). Data on damages due to weather events are from Spatial Hazard Events and Losses Database for the United States (SHELDUS). These data offer monetary estimates of damages caused by every natural hazard event that has caused injury, death, or property/farm damages since 1960 in the U.S. We include all the events in the data, including hurricanes, wildfires, tornadoes, etc.

To construct the instrument, we first sum the dollar value of weather damages to properties from SHELDUS at the state (s) by quarter $(q)$ level, then compute rolling historical averages (going back to 1960) of state $s$, adjusting for inflation. Since weather damages can vary by season, we construct historical averages for each quarter $q$ using historical data from the same quarter of previous years. We then subtract the rolling historical averages from the state-quarter level weather damages, to obtain what we call Unusual Weather Damages. By subtracting historical averages, Unusual Weather Damages should reflect the surprise weather damages that happen to a state in a quarter.

Second, we construct each P\&C insurer i's lagged market share in state $s$, quarter $q$, as insurer $i$ 's direct premiums written in state $s$ over the preceding four quarters, divided by the sum of the direct premiums written by all the P\&C insurers operating in state $s$ over the same period. We multiply this lagged market share at the insurer-state-quarter level with Unusual Weather Damages at the state-quarter level from the first step. We then sum the resulting products over all the states for each insurer, $\sum_{s}\left(\right.$ Unusual Weather Damages $_{s, q} *$ Lag Mkt Share $\left.{ }_{i, s, q}\right)$, and scale by lagged assets, to obtain the instrumental variable. See Ge (2020) for descriptive graphs and summary statistics on Unusual Weather Damages and the market shares across the states.

If we make the following assumptions, then the instrument can satisfy the exclusion restriction: 1) Unusual Weather Damages should be uncorrelated with insurers' lagged market share; 2) Unusual Weather 
Damages should be uncorrelated with omitted variables that affect insurers' investment decisions; 3) weather damages are stationary, in other words, Unusual Weather Damages have an expectation of zero. ${ }^{7}$

Our data on insurers' holdings in financial securities are from insurers' reports to NAIC, which can be downloaded from SNL and provides annual data on insurers' financial assets in broad categories. We collect data at the category level between 2001 and 2015. Panel A of Table 2 offers summary statistics on holdings in some major categories, whose average holding exceeds $5 \%$ in either the P\&C or life insurer sample. Besides cash, municipal and corporate bonds make up the largest portions of P\&C insurers' portfolios, while corporate bonds, MBS, and treasuries make up the largest portion of life insurers' portfolios. The value of the corporate bonds held by P\&C insurers at the end of 2015 was $\$ 269.24$ billion, and that by life insurers was $\$ 1.85$ trillion, totaling $\$ 2.12$ trillion, or 26\% of all corporate bonds outstanding in the U.S.

\subsection{Insurers’ Corporate Bond Holdings at the Security Level}

We obtain P\&C insurers’ CUSIP-level bond holding data between 2008 and 2015, which are based on insurers' annual statutory filings, Schedule D, Part 1. We also obtain data on insurers' acquisition and disposal of bonds between 2008 and 2015, reported in Q1, Q2, Q3 and annual filings, Schedule D, Parts 3 and $4 .{ }^{8}$ We use quarterly trading data to back out quarter-end holding information. The data offer information on the bond, for example, coupon rate, maturity, and NAIC designation for the risk charge of the bond at the time of reporting. The holding data offer the par, fair, and carry value of the holding. The trading data offer the actual cost and par value of a purchase or disposal.

From Mergent FISD, we obtain bond ratings and maturity dates. If the maturity date for the same bond is different between insurers' filings and those reported on Mergent, we use Mergent's. If the maturity

\footnotetext{
${ }^{7}$ Denote the factors that affect insurers' portfolio decisions that are orthogonal to controls (included in the empirical analysis) $X$. To satisfy the exclusion restriction, the correlation between P\&C Unusual Weather Exposure and $X$ needs to be zero. $\operatorname{Cov}\left(P \& C\right.$ Weather Exposure $\left.{ }_{i, s, q}, X\right)=\sum_{s} E$ (Unusual Weather Damage S $_{s, q} \cdot$ Lag Mkt Share $_{i, s, q}$. $X)-E(X)\left[\sum_{s} E\left(\right.\right.$ Unusual Weather Damage $_{s, q} \cdot$ Lag Mkt Share $\left.\left._{i, s, q}\right)\right]=\sum_{s}\left[E_{\left(\text {UnusualWeatherDamage }_{s, q}\right.} \cdot\right.$ LagMktShare $\left.\left._{i, s, q}\right) \cdot E(X)\right]-E(X) \cdot \sum_{s}\left[E\left(\right.\right.$ UnusualWeatherDamage $\left._{s, q}\right) \cdot E\left(\right.$ LagMktShare $\left.\left._{i, s, q}\right)\right]=0$ Assumptions 1 and 2 can generate the second-to-last equality. Assumption 3 can lead to the last equality. ${ }^{8}$ Although annual holding data of corporate bonds at the CUSIP-level are available through SNL since 2004, quarterly trading data are not available until 2008 through SNL.
} 
date for a certain bond is missing in both a specific insurer's filing and Mergent, we use the most frequent maturity date for that bond among all the P\&C insurers' Schedule D filings. We use TRACE (Trade Reporting and Compliance Engine) to calculate bond liquidity measures following Dick-Nielsen, Feldhütter, and Lando (2012) after cleaning the data following Dick-Nielsen (2009). We calculate the market value of each holding by multiplying the par value with the latest trading price of the bond in the prior quarter in TRACE.

A P\&C insurer holds an average of 74 corporate bonds each year, with a median of 32 . There are on average 24,395 unique CUSIPs per year among all the corporate bonds P\&C insurers hold. There are 83,966 unique CUSIPs in total, among all the corporate bonds in P\&C insurers' filings. Panel B of Table 2 offers summary statistics of CUSIP-level corporate bond holdings by P\&C insurers.

\section{Insurers' Size, Ratings, and Investments in Broad Categories}

In Panel C of Table 2, we sort insurers into three subsamples based on their asset size or A.M. Best financial strength ratings, respectively. We tabulate the averages of insurers' financial variables and portfolio weights of different asset categories for each subsample. If the averages of the smallest and largest (or bestand worst-rated) subsamples are statistically different at the 5\% level, the averages are displayed in bold.

Smaller asset size is associated with lower leverage, higher RBC ratios, and worse insurer ratings. This observation suggests that smaller firms tend to manage their leverage and RBC ratio in a way that keeps them further away from economic and regulatory default, but still receive lower ratings from agencies. Size appears to play an important role, beyond leverage and RBC ratios, in characterizing a firm's financial flexibility by the rating agency. Presumably, it is harder for an insurer to grow larger in assets than to lower its leverage or to increase its RBC ratio. To lower its leverage, an insurer can simply limit sales of policies that, in the short term, increase reserves (under liabilities) more than assets. To increase its RBC ratio, an insurer can limit such policy sales and invest heavily in treasury securities. 
Smaller or worse-rated insurers have larger portfolio weights on cash (including short-term investments) ${ }^{9}$ and government securities, and smaller weights on MBS and corporate bonds, relative to larger or better-rated insurers. The differences are substantial. For example, the average cash holding is 34\% among the smallest one-third of P\&C insurers and 9\% among the largest. The average corporate bond holding is $13 \%$ among the smallest $\mathrm{P} \& \mathrm{C}$ insurers and $22 \%$ among the largest. These patterns suggest that smaller or worse-rated insurers prefer safer, more liquid portfolios than larger or better-rated insurers. In addition, since cash and government securities also have lower risk charges than MBS and corporate bonds, smaller or worse-rated insurers could be trying to achieve higher RBC ratios with higher portfolio weights on cash and government securities. The difference in portfolio weights between better-rated and worse-rated insurers is similar to but smaller in magnitude than the difference between larger and smaller insurers.

How do we interpret the result that as insurers become larger, they tend to have larger allocations to risky and illiquid assets? One possibility is that larger insurers are more diversified in their operations and are exposed to less risk through their operations. Alternatively, it could be that larger insurers are less financially constrained and are less concerned about an increase in liquidity needs or the likelihood of insolvency. Panel A of Table A.3 indicates that larger insurers do have lower operating cash flow volatility. This result is consistent with the notion that larger insurers are exposed to less operating risk.

Panel B documents that asset size explains a substantial portion of the variation in ratings (based on the R-squared), and suggests that larger insurers have better financial strength ratings. The rating agency could potentially assign better ratings to larger insurers because of their smaller operating risk. Having a better rating could also mean better financial health and fewer financial frictions. A number of papers in the corporate finance and banking literature argue that size is highly correlated with firms' financial

\footnotetext{
9 "Cash" is from Summary Investment Schedule, Line 10, which includes cash, cash-equivalents (Schedule E Part 2) and short-term investments (Schedule DA Part 1 investments with one-year or less maturity at the time of acquisition including exempt money market funds and class one money market mutual funds).
} 
constraints. ${ }^{10}$ Since larger insurers enjoy better ratings, demand for their products or profitability is higher. ${ }^{11}$ Therefore, larger insurers can enjoy more market power that makes it easier for them to obtain more policy premiums and retained earnings, which reduces financing frictions. The results in Table A.3 are consistent with both interpretations of insurers' size: it can reflect that size is negatively related to risk exposure, and also can be associated with lower financial constraints.

Presumably, the reason why larger insurers allocate more of their portfolios to riskier and more illiquid securities is to receive higher expected returns. Therefore, given that larger insurers have riskier and more illiquid portfolios than smaller insurers, insurers' expected returns should be positively correlated with their size. Therefore, on average, we expect insurers to achieve higher realized returns when they are larger. We test this prediction in Table A.4 in the Appendix. The estimate in Column (1) implies that for life insurers, a one standard deviation increase in Log Assets leads to a 9 basis point increase in realized quarterly returns, which is $8 \%$ of the median quarterly return (1.2\%). The estimate in Column (2) implies that for P\&C insurers, a one standard deviation increase in Log Assets leads to an 8 basis point increase in realized quarterly returns, which is $10 \%$ of the median quarterly return $(0.8 \%)$.

Larger insurers' higher realized returns could reflect returns on the risk and illiquidity that larger insurers' portfolios are exposed to, or due to chance/luck during our short sample period. It could also be the case that larger insurers have more skills in their investment. To understand the cause of larger insurers' higher realized returns, we examine $\mathrm{P} \& \mathrm{C}$ insurers’ corporate bond portfolio, for which there are widely accepted measures for risk and illiquidity. In Columns (3) and (4), we present estimates of equations in which the dependent variable is the value-weighted average corporate bond realized returns. Column (3) suggests that larger insurers indeed earn higher realized returns on their corporate bond portfolios. A one standard deviation increase in insurers' size corresponds to an increase of 0.4 percentage point in insurers' realized returns. In Column (4), we include value-weighted averages of corporate bond ratings and two

\footnotetext{
${ }^{10}$ See, for example, Almeida, Campello, and Weisbach (2004), Hadlock and Pierce (2010), Campello, Graham, and Harvey (2010), and Kashyap and Stein (2000).

${ }^{11}$ For discussion and evidence on this point, see Epermanis and Harrington (2006) for P\&C insurance and Koijen and Yogo (2015) for life insurance.
} 
illiquidity measures. The coefficient on insurers' size becomes $20 \%$ smaller than that in Column (3), but remains statistically significant. This result suggests that during our sample period, larger insurers' higher realized returns on their corporate bond portfolio cannot be fully explained by the risk and illiquidity captured in our measures.

If larger insurers' higher realized returns in their corporate bond portfolios can be explained by other risks they take in their corporate bond investments, then the yields on their corporate bond portfolio should also be higher after controlling for the risk and illiquidity in their portfolio. In Columns (5) and (6), we replace the dependent variable with the value-weighted average annual yield of each insurer's corporate bond portfolio at the end of each quarter. Column (5) suggests that larger insurers' corporate bond investments have higher yields: a one standard deviation increase in insurers’ assets corresponds to a 0.17 percentage point increase in the expected annual yields of their corporate bond portfolio, which is $5 \%$ of the median (3.3\%).

In Column (6), we add value-weighted averages of the bond ratings and illiquidity. The estimated coefficient on insurers' asset size becomes statistically insignificant, while bond ratings and illiquidity measures all have positive and statistically significant estimated coefficients. The result in Column (6) suggests that most of the additional priced risks larger insurers take in their corporate bond portfolios, compared to smaller insurers, are credit and illiquidity risks. Column (6) suggests that it is unlikely that larger insurers earned higher realized returns—as shown in Column (4)—by taking on priced risks beyond credit and illiquidity risk. Larger insurers could have earned higher realized returns either due to chance or luck during our short sample period, or due to their "skills". One of the "skills” could be getting better prices in their trades as argued by O’Hara, Wang, and Zhou (2018). Another “skill” could be larger insurers’ better ability to predict bond default. 


\section{The Impact of Insurers' Operating Losses on Their Investments in Corporate Bonds}

\subsection{Insurers' Operating Losses and Investments in Corporate Bonds}

The summary statistics in Panel C of Table 2 suggest that larger insurers invest larger fractions of their portfolios in cash and government securities than smaller insurers. Cash and government securities are safe and liquid, and are subject to more lenient regulatory treatment through lower risk charges. What makes cash and government securities more attractive to smaller insurers than to larger ones? These portfolio choices could occur because of risk and liquidity management incentives related to insurers’ size. However, it is also possible that these choices occur because of regulation since different asset classes have different regulatory treatments in terms of risk charges (see Table 1). Distinguishing between these explanations is complicated by the fact that asset classes differ systematically in their risk, liquidity, and regulatory treatment. However, since securities in an asset class or a given subgroup within it are treated the same by regulators, it is possible to evaluate the importance of investors' financial conditions by examining choices within a given asset class. We next focus on corporate bonds since they constitute one of the largest categories in insurers' portfolios and have substantial variation in their riskiness and liquidity. In addition, there are commonly accepted measures of corporate bonds’ risk and liquidity.

As we discussed earlier, there are at least two explanations for the pattern that larger insurers invest in riskier assets. One possible explanation is that larger insurers have smaller exposure to risks from their underwriting activities due to their more diversified operations. Alternatively, larger insurers could have more financial flexibility and are therefore less concerned about the riskiness and illiquidity of securities when constructing their portfolios.

To evaluate whether insurers' financial conditions affect their portfolio choices, we use insurers' operating losses as shocks to their financial strength. Such shocks are especially important in the P\&C business, where a weather-related disaster can lead to a large number of claims in a region where a particular 
insurer has a substantial market presence. Unusual weather events are exogenous shocks that can substantially affect an insurer’s financial condition.

For the reasons above, we next estimate the extent to which P\&C insurers' operating losses can cause insurers to change their corporate bond holdings, using data on the individual bonds held by each insurer in this specification:

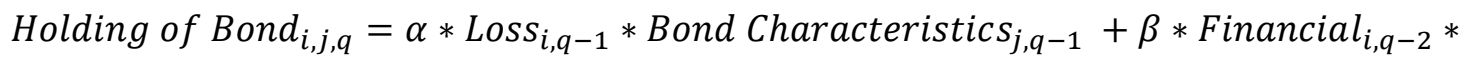

Bond Characteristics $_{j, q-1}+F E_{i, q}+F E_{j, q}+e_{i, j, q}$,

where Holding of Bond is the market value of any particular bond $j$ that the insurer $i$ holds in quarter $q$ scaled by the insurers' cash and invested assets or scaled by the market value of all the corporate bonds held by the insurer. We use the market value of the bond holdings instead of book value because of the concern that insurers endogenously choose their own calculation of the book value (Sen and Sharma 2020). Loss is the operating losses due to insurers' underwriting activities (net of reinsurance payments) from $q-1$ scaled by insurers' assets from q-2. Bond Characteristics is a vector of bond characteristics, including Bond WorseRated, illiquidity, coupon rate, maturity, an indicator for bonds downgraded in $q-1$, and an indicator for bonds in the NAIC 1 category. We use lagged Bond Worse-Rated as our measure of the bond's risk. We transform different rating agencies' latest bond ratings to numeric values and take the average across different rating agencies. For bonds in the NAIC 1 category, Bond Worse-Rated is 1 for bonds rated AAA, and increases to 7 for bonds rated A- (see Table A.2 in Appendix). For bonds in the NAIC 2 category, Bond Worse-Rated is 1 for bonds rated BBB+, 2 for BBB, and 3 for BBB-, so that bonds in NAIC 1 and 2 categories have some common support for this variable. To measure bond illiquidity, we use the number of days without trading as a fraction of the total number of trading days in the main specification and use the imputed round-trip costs in a robustness test.

Insurers’ Financial includes Log Assets, Insurer Rating, and Leverage, all from $q$-2, as well as RBC Ratio from the prior year as it is only available annually. To address the possibility that operating losses and insurers' financial portfolios can be both related to insurers' unobservable characteristics (e.g. management quality), we instrument for operating losses using the weather-based instrument described in Section 3. We 
control for bond CUSIP-year-quarter fixed effects, so we are essentially comparing an insurer's holding of a bond with other insurers' holding of the same bond in the same quarter. We also include insurance firmyear-quarter fixed effects to control for the average pattern in an insurer's bond holding in a certain quarter.

Table 3 presents estimates of Equation (1). Columns (1)-(4) are estimated using only bonds in the NAIC 1 category. Such bonds make up 57\% of the corporate bonds held by P\&C insurers (equally weighting the bonds). Columns (1) and (3) present estimates using OLS and Columns (2) and (4) include the secondstage results when instrumenting for operating losses using the weather-based instrument. Table A.5 presents the first-stage results corresponding to Column (4). Columns (5)-(8) repeat the specifications presented in Columns (1)-(4) but include all the bonds in NAIC 1 and 2 categories. These two categories make up 90\% of P\&C insurers' corporate bond holdings.

In each column of Table 3, the coefficient on the interaction term between Loss and Bond WorseRated is negative and statistically significantly different from zero, suggesting that following operating losses, $\mathrm{P} \& \mathrm{C}$ insurers reduce their holdings of riskier corporate bonds. The corresponding coefficient in the instrumental variable specifications presented in the even-numbered columns is statistically significant and of similar magnitude as the corresponding coefficient in the OLS specification. This finding suggests that the relationship between an insurer's losses and changes to its portfolio is causal, and does not occur because of a spurious correlation between the two.

To illustrate the magnitude of the estimated effect, consider two hypothetical corporate bonds, where Bond 1 is rated A- and Bond 2 is rated AAA, the difference being six notches. The instrumental variable estimates in Column (2) imply that following one standard deviation of losses (4.6\% of lagged assets), insurers’ holdings of Bond 1 will decrease by 0.05 percentage point relative to Bond 2, which is $39 \%$ of the median holding of the sample used in the regression $(0.12 \%)$ and $14 \%$ of the standard deviation $(0.33 \%) .{ }^{12}$

The interaction terms between Loss and Bond NAIC 1 Dummy in the specifications estimated in Columns (5)-(8) have positive and statistically significant coefficients. These coefficients suggest that after

\footnotetext{
${ }^{12}$ The coefficient estimates in Columns (3), (4), (7), and (8) are larger since the dependent variable is scaled by a smaller number (insurers' total corporate bond holdings), and hence has a larger value.
} 
insurers suffer losses, they tend to weight their portfolio more heavily toward bonds in the safer NAIC 1 category and more lightly from bonds in the riskier NAIC 2 category. The estimate in Column (6) implies that following one standard deviation of losses (4.6\% of lagged assets), an average insurer's holdings of bonds in the NAIC 1 category will increase by 0.03 percentage point relative to bonds in the NAIC 2 category, which is $29 \%$ of the median and $10 \%$ of the standard deviation. These results are consistent with the findings reported above: following losses, insurers shift their portfolio towards safer securities.

\section{Duration of the Effect}

To see how long the effect of insurers' losses on their corporate bond portfolio lasts, we use a leadlag plot. The plot can also illustrate whether there is "pre-trend": whether insurers change their corporate bond portfolios prior to the losses. Figure 1 plots the estimates of coefficients, $\alpha_{n}$, and their corresponding 95\% confidence interval from the regression below.

${\text { Holding of } \text { Bond }_{i, j, q}=\sum_{n=-5}^{10} \alpha_{n} * \operatorname{Loss}_{i, q-n} * \text { Bond Worse-rated }}_{j, q-1}+\sum_{n=-5}^{10} \beta_{n} *$ Loss $_{i, q-n} *$

Other Bond Char $_{j, q-1}+\gamma *$ Financial $_{i, q-11} *$ All Bond Char $_{j, q-1}+F E_{i, q}+F E_{j, q}+e_{i, j, q}$,

where $n$ does not equal zero. When $n$ is between 1 and 10, the $\operatorname{Loss}_{q-n}$ precede insurers' holdings in $q$, and the estimated coefficient, $\alpha_{n}$, reflects how losses in quarter $q$ affect insurers' holdings of riskier versus safer bonds in $q+n$. These coefficients are plotted to the right of the vertical line in Figure 1. For example, the estimate of $\alpha_{1}$ is the first point to the right of the vertical line, representing how insurers' losses in $q$ affect holdings of riskier versus safer bonds in $q+1$. The magnitude of the effect of the losses in $q$ on insurers' holdings increases from $q+1$ to $q+4$ before declining to statistically indistinguishable in $q+8$. Thus, the effect of insurers’ losses on their corporate bond portfolios persists for around seven quarters.

When $n$ is between -5 and -1 , the estimated coefficient, $\alpha_{n}$, reflects how losses in quarter $q$ are related to insurers' holdings of riskier versus safer bonds before $q$. These coefficients are plotted to the left of the vertical line in Figure 1. As the figure shows, none of these coefficients is statistically significantly different from zero, suggesting that insurers' losses are not related to their past holdings of riskier versus 
safer bonds. This result serves as additional reassurance that insurers' operating losses are plausibly shocks that induced a shift in insurers’ portfolios.

\section{Robustness}

In Panel A of Table A.6 in the Appendix, we present several robustness checks with variants of the specification used in Column (5) of Table 3. In Column (1), we add Bond Duration in quarter $q-1$ as one of the characteristics of bonds. In Column (2), we omit Bond Coupon Rate and Bond Maturity, and include Bond Duration. In Column (3), we use Imputed Round Trip Costs as a proxy for bond illiquidity. The results described above hold in each of these specifications. Following losses, insurers' shift in corporate bond portfolios does not appear to be a function of the bonds' duration. In Column (4), we use bonds' yield to maturity from the previous quarter as the measure for bond risk. The coefficient on the interaction term between $P \& C$ Loss and bond yield is not statistically significantly different from zero. One potential explanation of this finding is that as insurers try to decrease the riskiness of their portfolios following operating losses, they use a bond's rating as their measure for bond riskiness, rather than calculating the yields by obtaining the latest trading prices. ${ }^{13}$ In Column (5), we repeat the original specification, replacing the insurance firm-year-quarter fixed effects with firm fixed effects and adding firms' lagged financial variables as controls. The estimates from this specification are similar to those in Table 3. Table IA.1 in the Internet Appendix repeats Table 3, using bond characteristics from quarter $q-2$ in Panel A, and those from quarter $q$ in Panel B. The results highlighted here remain similar.

If operating losses reflect negative shocks that worsen insurers' financial conditions and insurers change their portfolio allocation as a result, we expect insurers to shift towards riskier bonds after experiencing operating gains. In Panel B of Table A.6, we repeat Table 3, replacing Loss with Gain, which equals net underwriting gain scaled by lagged assets if net underwriting gain is positive, and zero otherwise. The results suggest that insurers indeed shift towards riskier bonds after experiencing operating gains.

\footnotetext{
${ }^{13}$ Another potential reason is the correlation between bond yields and the NAIC 1 Dummy.
} 


\section{Control Variables}

Turning back to Table 3, the coefficients on some of the control variables are worth noting. The positive and statistically significant coefficients on the interaction term between Log Assets and Bond WorseRated suggest that $\mathrm{P} \& \mathrm{C}$ insurers with larger assets have a larger portfolio weight on riskier bonds. To illustrate the magnitude of this difference, suppose again there are two bonds: Bond 1 is rated A- and Bond 2 is rated AAA. Column (1) suggests that a one standard deviation smaller asset size is associated with a 0.044 percentage point decrease in the holding of Bond 1 relative to Bond 2, which is $37 \%$ of the median $(0.12 \%)$ and $13 \%$ of the standard deviation $(0.33 \%)$.

The negative and statistically significant coefficients on the interaction term between Insurer Rating and Bond Worse-Rated suggest that worse-rated insurers have a smaller portfolio weight on riskier bonds. Column (1) implies that a one standard deviation worse insurer rating (2.5 notches) is associated with a 0.022 percentage point decrease in the holding of Bond 1 (rated A-) relative to Bond 2 (rated AAA), which is 18\% of the median and $7 \%$ of the standard deviation. These results are consistent with the idea that smaller or worse-rated insurers prefer safer securities more than other insurers.

The interaction terms between Log Assets and Bond NAIC 1 Dummy have negative and statistically significant coefficients, suggesting insurers' smaller size is associated with holding more bonds in the safer NAIC 1 category relative to the riskier NAIC 2 category. In Column (5), the coefficients imply that a one standard deviation decrease in insurers' assets is associated with a 0.06 percentage point increase in the holding of bonds in the NAIC 1 relative to the NAIC 2 category, which is $50 \%$ of the median and $18 \%$ of the standard deviation.

The interaction terms between Insurer Rating and Bond NAIC 1 Dummy have positive and statistically significant coefficients, suggesting that worse-rated insurers hold more of bonds in the safer NAIC 1 category relative to the riskier NAIC 2 category. Column (5) implies that a one standard deviation worse insurer rating is associated with a 0.016 percentage point increase in the holding of bonds in the NAIC 1 relative to the NAIC 2 category, which is $17 \%$ of the median and $6 \%$ of the standard deviation. 
These results could be explained by smaller and worse-rated insurers' incentives to achieve higher $\mathrm{RBC}$ ratios, since bonds in the NAIC 1 category have a lower risk charge compared to those in the NAIC 2 category. However, these results are also consistent with our conclusion from the within-NAIC category observation: smaller and worse-rated insurers have a stronger preference for safer corporate bonds, compared to other insurers.

The positive, statistically significant coefficients on the interaction term between Log Assets and Bond Illiquidity suggest that P\&C insurers with larger assets have larger portfolio weights on more illiquid bonds. The negative, statistically significant coefficients on the interaction term between Insurer Rating and Bond Illiquidity suggest that P\&C insurers with better ratings have larger portfolio weights on more illiquid bonds. The economic magnitudes are small. However, it could be the case that when large and better-rated insurers hold a certain bond, they hold a large portion of the bond outstanding and do not trade the bond often, thus causing the bond to appear more illiquid.

The magnitude of the effect of insurers' financial variables on their holdings across bonds with different risk and liquidity levels is relatively small. These results nonetheless provide evidence that the large difference in holdings across categories between small and large (or worse-rated and better-rated) insurers can at least be partially due to the safety and liquidity of cash and government securities relative to MBS and corporate bonds. It does not appear to be entirely driven by the more lenient regulatory treatment of cash and government securities.

It is interesting to note that the estimated coefficients on $R B C$ Ratio*Bond Worse-Rated are all negative, suggesting that insurers with higher RBC ratios hold less of worse rated bonds. Based on Column (2), if an insurer's RBC ratio is higher by one standard deviation (25.6), its holdings of a bond rated A- is lower by 0.015 percentage point relative to a bond rated AAA, which is $13 \%$ of the median holding and $5 \%$ of the standard deviation. This effect is smaller than that of a one standard deviation increase in insurers' losses, which is $39 \%$ of the median holding and $14 \%$ of the standard deviation.

The positive coefficient estimates on RBC Ratio*Bond NAIC 1 Dummy suggest that insurers with RBC ratios hold more of bonds with the NAIC 1 designation. Column (6) implies that, if an insurer's RBC 
ratio is higher by one standard deviation, insurers' holdings of bonds in the NAIC 1 category will increase by 0.018 percentage point relative to bonds in the NAIC 2 category, which is $15 \%$ of the median and $5 \%$ of the standard deviation. This effect is again smaller than that of a one standard deviation increase in insurers' losses, which is $29 \%$ of the median and $10 \%$ of the standard deviation. These two results related to insurer' $\mathrm{RBC}$ ratios could be because insurers' desire to maintain a high $\mathrm{RBC}$ ratio is correlated with their desire to hold a safer portfolio. It could also be the case that insurers that prefer a higher RBC ratio achieve it by investing more in bonds with NAIC 1 designation.

\subsection{Heterogeneity in the Effect of Losses on Investments in Corporate Bonds}

The results in Section 5.1 indicate that after operating losses, P\&C insurers shift their corporate bond portfolios towards safer bonds. We have argued that this shift likely occurs because the operating losses tighten insurers' financial constraints. This explanation predicts that insurers' portfolios should have a larger shift to safe bonds following losses if the effect of losses matters more for them. We hypothesize that the effect of losses should be more important for insurers that are smaller or worse-rated. The reason is that these insurers are likely exposed to more risk in their future operation or are more financially constrained prior to the losses. A negative shock today can cause these insurers' financial conditions to worsen by more, relative to other insurers. We also predict that during the financial crisis, when financing frictions are more severe, the effect of operating losses on insurers' allocation across bonds is more pronounced. To test these hypotheses, we estimate the following specification in Panel A of Table 4:

Holding of Bond B $_{i, q}=\gamma *$ Dummy $^{*} \operatorname{Loss}_{i, q-1} *$ Bond Char $_{j, q-1}+\alpha * \operatorname{Loss}_{i, q-1} *$ Bond Char $_{j, q-1}+\beta *$

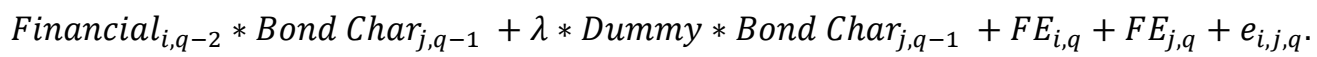

In Columns (1) and (2), Dummy is Insurer Small Dummy, which equals one if the insurer is smaller than the median in quarter q-2. In Columns (3) and (4), Dummy is Insurer Worse Rated Dummy, which equals one if the insurer's rating is worse than the median in quarter q-2. In Columns (5) and (6), Dummy is the Crisis Dummy, which equals one for 2008 and 2009 and zero otherwise. Bond Char is a vector of bond characteristics included in Table 3. Financial is a vector of insurers' financial variables included in Table 3. 
The estimated coefficients on the triple interaction terms between Dummy, Loss, and Bond WorseRated are all negative and statistically significantly different from zero. This result suggests that insurers decrease their holdings of riskier bonds by more following losses if the insurers are smaller or worse-rated, and if it is during 2008 and 2009. To illustrate the magnitude of these estimates, again compare a bond rated A- and another rated AAA. The estimated coefficient in Column (1) implies that, following one standard deviation of losses, smaller insurers' holdings of the bond rated A- will decrease by 0.03 percentage point (21\% of the median holding) relative to the bond rated AAA, compared to the holdings of larger insurers.

Instead of using triple interactions in the regressions, we also estimate Equation (1), repeating Columns (1) and (5) of Table 3, using subsamples that are likely to be more versus less affected by losses. In the top half of Panel $\mathrm{C}$ of Table 4, we report the coefficients on the variable that we care most about, Loss*Bond Worse-Rated, estimated using different subsamples. The estimates are always negative in each of the subsamples, and more negative for smaller (worse-rated) insurers than larger (better-rated) insurers. The estimates are also more negative during the crisis than outside of the crisis. These results confirm those in Panel A and suggest that insurers' losses have a larger effect on insurers' financial portfolios if the insurers' financial conditions are more likely to be worsened by losses.

Overall, the results described in this subsection provide additional support for the view that when insures structure their portfolios, they consider their financial conditions: insurers shift to a safer portfolio when they become more financially constrained. As such, the results here highlight the role of financial constraints in the portfolio choice of insurers.

\subsection{Regulation, Losses, and Investments in Corporate Bonds}

To what extent is the shift towards a safer portfolio after losses purely driven by regulation? If regulation drives our results, then insurers with low RBC ratios and that are therefore more likely to attract regulators' attention should see a larger effect of losses on their corporate bond holdings. We next examine whether insurers below or near the regulatory lower bound for RBC ratios are more likely to shift towards safer portfolios following losses. 
In Panel B of Table 4, we estimate Equation (3) replacing Dummy with RBC-Related Measure based on insurers' RBC ratio in the prior year: a dummy variable equal to one if insurers' RBC ratio in the prior year is below two (a lower bound that triggers regulatory intervention) in Columns (1)-(2), below five in (3)(4), and below the median in (5)-(6). In Columns (7)-(8), this RBC-ratio-related measure equals the continuous $\mathrm{RBC}$ ratio from the prior year. A larger RBC ratio indicates that the insurer is further away from the regulatory lower bound. Odd-numbered columns only use bonds in the NAIC 1 category and evennumbered columns use bonds in both NAIC 1 and 2 categories.

In all of the columns, the negative and statistically significant coefficients on the interaction term between Loss and Worse-Rated suggest that, on average, insurers with RBC ratios higher than the corresponding cutoffs do shift towards safer bonds following losses. In Column (1), the coefficient on RBCRelated Measure*Loss*Worse-Rated is statistically significantly different from zero, suggesting that insurers, whose RBC ratio is below the regulatory lower bound of two, respond more strongly to losses by shifting towards safer bonds. In Column (3), where the RBC ratio cutoff is five, the coefficient on this interaction term is statistically significant and negative, but of much smaller magnitude than the one in Column (1). The other six coefficients on RBC-Related Measure*Loss*Worse-Rated are not statistically significantly different from zero, suggesting that insurers close to the regulatory lower bound and those further away from it do not respond differently to operating losses. These results suggest that insurers' increased portfolio weights on safer bonds following losses are unlikely to be only driven by regulation.

We also estimate Equation (1), repeating Columns (1) and (5) of Table 3, with subsamples of insurers based on their RBC ratio using the three cutoffs mentioned above. We report the estimates of the coefficients on Loss*Bond Worse-Rated using these subsamples in the bottom half of Panel C of Table 4. The estimates are always negative in each of the subsamples expect for insurers with an RBC ratio lower than two. The coefficients on Loss*Bond Worse-Rated are more negative for insurers with lower RBC ratios than those with higher RBC ratios, when we use five or the median as the cutoff. However, the differences between these subsamples are much smaller than the differences between subsamples sorted on insurers' size or ratings. In Panel B, the estimates of the coefficient on RBC-Related Measure*Loss*Bond Worse- 
Rated are usually not statistically significant, suggesting that the subsamples sorted on insurers' RBC ratios do not see a statistically significantly different effect of losses in choosing between riskier and safer corporate bonds. Overall, the results indicate that insurers' shift towards safer securities is unlikely due to regulatory pressure, because insurers with lower RBC ratios are more likely to be scrutinized by regulators but they do not behave consistently differently from other insurers.

We next consider whether other regulatory rules or interventions drive our results that insurers shift towards safer bonds following losses. If regulators demand that insurers shift portfolio towards safer securities, presumably such regulatory actions should take place when an insurer's RBC ratio falls below the regulatory lower bound-when insurers are explicitly under regulators' scrutiny. We find that when insurers' RBC ratios fell below two in year $t-1,42 \%$ of the time they still purchase corporate bonds in the NAIC 2 category in the quarters of year $t$. The dollar amount they spend buying bonds in NAIC 2 category is on average $53 \%$ of the amount they spend buying bonds in the NAIC 1 category. These observations suggest that it is unlikely that regulators urge insurers to stay away from bonds in the NAIC 2 category. Therefore, our results when restricting to bonds in the NAIC 1 category are unlikely a result of regulators forcing insurers to shift towards a safer portfolio.

In addition, we restrict our analysis to insurer-quarter observations for which the insurer buys NAIC 2 category bonds and only examine their investment within the NAIC 1 category in the same quarter. If an insurer buys bonds in the NAIC 2 category, then regulators would most likely give them the freedom to invest in bonds in the safer NAIC 1 category. It is unlikely that, while regulators allow insurers to invest in NAIC 2 category securities, they also steer insurers to shift to safer securities within the NAIC 1 category. Thus, the investment within the NAIC 1 category is likely to be free of the influence from the regulators when insurers purchase NAIC 2 category bonds. In Table 5, we repeat Columns (1)-(4) of Table 3 while restricting to insurer-quarter observations where insurers also purchased NAIC 2 category bonds in the same 
quarter. ${ }^{14}$ The results remain similar to those in Table 3. Therefore, it is unlikely that insurers' shift towards safer bonds is only a result of regulators' pressure.

\subsection{Extremely Large Losses and Insurers’ Investments in Corporate Bonds}

We have documented that as insurers' financial conditions worsen, their portfolios tend to become less risky. An important issue in interpreting these results is the extent to which they are driven by extremely large losses. Theoretically, if insurers exhibit stronger risk-shifting behavior in any situation, it would occur when they suffer large losses and are close to insolvency. We next evaluate whether the tendency toward safer securities when conditions worsen applies in the case of extremely large losses.

Table 6 estimates a spline specification by splitting the Loss variable into two variables. One is Loss $<=$ Cutoff, which equals the losses if they are not larger than the cutoff, and equals the cutoff if losses are above the cutoff. The other variable is Loss>Cutoff, which equals losses minus the cutoff if losses are above the cutoff, and zero otherwise. The cutoff is the median, the $75^{\text {th }}$ percentile, or the $95^{\text {th }}$ percentile of the positive losses of each quarter in different columns. For an insurer whose losses are below the cutoff, Loss $<=$ Cutoff will equal the losses, and Loss $>$ Cutoff will equal zero. For an insurer whose losses are above the cutoff, Loss $<=$ Cutoff will equal the cutoff, and Loss $>$ Cutoff will equal its losses minus the cutoff.

The negative and statistically significant coefficients on Loss $<=$ Cutoff*Bond Worse-Rated suggest that the results in Table 3 are not driven by extreme losses. In addition, with large losses, insurers' portfolios do not become riskier, implying that even in the circumstances that are likely to be most conducive to risk shifting, insurers nonetheless appear to decrease risk in response to losses. The estimated coefficients on Loss $>$ Cutoff $*$ Bond Worse-Rated are smaller in absolute value than those on Loss $<=$ Cutoff*Bond WorseRated, implying that an extra unit of Loss has a larger effect on insurers' shifting towards safer bonds when losses are small compared to when losses are large. This result could be due to that the marginal cost of

\footnotetext{
${ }^{14}$ Why would insurers buy bonds in the NAIC 2 category while shifting towards safer bonds in the NAIC 1 category? There are many considerations in insurers' choices of securities to hold, including industry diversification, maturities, etc. Their desire to shift towards safer bonds changes the tradeoff between the riskiness and other aspects of the bonds, but do not completely preclude them from investing in bonds that are not the safest.
} 
adjusting to a safer portfolio becomes higher when a lot of adjustment has already been done. The total effect of losses on insurers' portfolio shift is still larger when losses are larger, as most of the estimated coefficients on Loss>Cutoff*Bond Worse-Rated are negative: the losses beyond the cutoffs continue to shift insurers' portfolios towards safer bonds in addition to the effect of the losses below the cutoffs.

\subsection{Do Insurers’ Losses Affect Which Bonds They Sell and Which Bonds They Buy?}

Table 7 examines the way in which insurers adjust their portfolio following losses in more detail, by considering the purchases and sales of bonds separately. In Columns (1) and (2), we report estimates of Equation (1) replacing the dependent variable with the amount spent by insurer $i$ for buying bond $j$ in quarter $q$, scaled by insurer $i$ 's cash and invested assets. We include all the corporate bonds that any P\&C insurer bought in that quarter, and, thus, assume an insurer could conceivably buy any of these bonds. The dependent variable is zero if insurer $i$ does not purchase any of bond $j$ in quarter $q$. The coefficients on the interaction term between Loss and Bond Worse-Rated are negative and statistically significantly different from zero, suggesting that following operating losses, insurers' preference for buying safer bonds relative to riskier bonds become stronger. Column (1) suggests that when losses increase by one standard deviation, insurers decrease their purchase of A- relative to AAA bond by $68 \%$ of the mean.

In addition, the coefficients on the interaction term between Loss and Bond Illiquidity are negative and statistically significant, suggesting that, following operating losses, insurers' preference for more liquid bonds relative to less liquid bonds becomes stronger. Columns (1)-(2) also suggest that smaller insurers buy more bonds that are safer, more liquid, and in the NAIC 1 category, compared to larger insurers. In addition, worse-rated insurers tend to buy more liquid bonds compared to those purchased by better-rated insurers.

In Columns (3) and (4), we estimate Equation (1), replacing the dependent variable with the par value of bond $j$ that insurer $i$ sold in quarter $q$, as a fraction of the par value of bond $j$ insurer $i$ held. We exclude transactions that are involuntary, for example, due to bond maturing or being called by the issuer. If insurer $i$ holds bond $j$ in quarter $q$, but does not sell bond $j$ in quarter $q$, the dependent variable for $i, j, q$ is zero. The estimated coefficients on the interaction term between Loss and Bond Worse-Rated are positive, 
suggesting that insurers sell more of riskier bonds relative to safer bonds following losses. However, these estimated coefficients are not statistically significantly different from zero.

The results in Panel A of Table 7 are consistent with the idea that when more constrained, insurers increase the portfolio weight on safer and more liquid assets. However, the effect is much larger for purchases than for sales. Rather than paying the transaction costs selling bonds in their portfolios, insurers likely change their portfolios following losses by replacing bonds that mature with safer ones.

Next, we present summary statistics on the buying and selling of corporate bonds by insurers that experience losses in the prior quarter and those that do not. For each bond that is acquired by any P\&C insurer in quarter $q$, we calculate the average purchase (costs scaled by insurers' cash and invested assets, zero for insurers that do not buy the bond) for two subsamples: insurers that suffered losses in $q-1$ and insurers that did not. Thus, each bond-quarter observation has two averages. Then we group bonds into different groups and calculate the mean (median) of the bond-quarter level average purchases for insurers with and without losses. Panel B of Table 7 presents the results. A bond is put in the following groups in quarter $q$ based on its NAIC designation and rating in quarter $q-1$. Bonds in the NAIC 1 category are sorted into safer (included in Column (1)) and riskier (included in Column (2)) groups based on their ratings with the median as the cutoff. Similarly, bonds in the NAIC 2 category are sorted by ratings into safer (included in Column (3)) and riskier (included in Column (4)) groups. Bonds in the NAIC 3-6 categories are included in Column (5). Therefore, from Column (1) to Column (5), bonds become riskier.

Row a (b) tabulates the mean of the bond-quarter average purchases among insurers with (without) losses in $q$-1. Row c tabulates the difference between Rows a and b. Row d tabulates the difference (Row c) as a percentage of Row b, the mean across bonds of the average purchase among insurers without losses. Rows e-h repeat Rows a-d replacing the mean with the median of the bond-quarter average purchase.

Based on Rows a, b, e, and $\mathrm{f}$ in Columns (1)-(5), the average purchase of bonds decreases if the bond is riskier, for both insurers with and without losses. Based on Rows $d$ and $h$ in Columns (1)-(5), the mean (or median) of the average purchase by insurers with losses minus that by insurers without losses is positive for the safer bonds and decreases to negative for riskier bonds. For example, the median of the 
average purchase of the safest group of bonds by insurers with losses is $40 \%$ larger than that by insurers without losses. The median of the average purchase of the riskiest group of bonds by insurers with losses is 53\% smaller than that by insurers without losses. The patterns suggest that insurers with losses have a stronger preference for safer bonds compared to insurers without losses, either within the same NAIC designation or across different ones.

We also sort bonds based on their illiquidity, measured by the fraction of zero trading days in quarter $q-1$, using the median as the cutoff. More liquid bonds are included in Column (6), and more illiquid bonds in (7). Columns (6)-(7) indicate that insurers with or without losses both buy more of liquid than illiquid bonds. Comparing the differences between the two groups of insurers in their purchase of liquid versus illiquid bonds, the results suggest that insurers with losses have a stronger preference for more liquid bonds.

Row i tabulates the correlation of bond-quarter average purchase among insurers with losses and the average among those without losses in $q-1$. The correlations are higher for the safer than the riskier bonds. The correlation is around 0.7 for bonds in the NAIC 1 category, suggesting that the average purchase of such bonds by insurers with losses and that by insurers without losses are highly correlated.

In Panel C of Table 7, we conduct a similar exercise with insurers’ disposal of bonds. For each bond held by any insurer in quarter $q$, we calculate the insurer-bond-quarter $(i, j, q)$ level disposal as the percentage of the par value of the bond $j$ insurer $i$ sold in $q$, and zero if no sale was made. We then take the average disposal for each bond-quarter of the two subsamples of insurers: those with and those without losses in $q$ 1. Similar to Panel A, we sort bonds into different categories, using the median in this sample as cutoffs for safer vs. riskier and more liquid vs. more illiquid. We tabulate the mean and 90th percentile ${ }^{15}$ of the average sales in the two subsamples of insurers, as well as the difference between the two.

The numbers in Row a (e) are always larger than the numbers in Row b (f), implying that insurers with losses sell more bonds on average than insurers without losses in all the categories of bonds. This result could be due to that insurers with losses have a larger need to rebalance their portfolio following the shock.

\footnotetext{
${ }^{15}$ Because the median (and even 75th percentile) of the average sales is often zero, we report the 90th percentile in Rows e-f instead of the median.
} 
Across bond categories of different riskiness, the largest difference between the two subsamples of insurers is in the riskiest category of bonds, those with NAIC 3-6 designations. This result implies that insurers with losses have a stronger “distaste” for these riskiest bonds compared to insurers without losses.

Columns (6) and (7) suggest that insurers with and without losses both sell more of liquid bonds, presumably because selling these bonds incur smaller discounts (or trading costs) compared to selling illiquid bonds. The difference between the two subsamples of insurers is larger for illiquid than liquid bonds, suggesting that insurers with losses are more willing to incur the larger trading costs associated with selling illiquid bonds to achieve a more liquid portfolio.

Row i tabulates the correlation of bond-quarter average disposals among insurers with losses and that among those without losses in $q-1$. The correlations are much lower compared to those in Panel A, suggesting that the sell decisions among insurers with losses and without losses are less correlated than their purchase decisions.

Overall, the results in Panels B and C echo those in Panel A. Together, they suggest that following losses, insurers’ preferences for safer and more liquid bonds become stronger.

\section{Summary and Discussion}

Endowments, foundations, pension funds, and insurance companies are among the most important investors in the economy, with assets totaling over \$22 trillion in 2017 in the U.S. These investors are different from professionally managed portfolios such as mutual funds and hedge funds because they rely (at least in part) on the returns generated from their investments to fund their operations. While there has been substantial research on some of these investors' activities such as their activism programs, there has been much less work on the more basic question of how these investors determine which securities to include in their portfolios. This paper studies the investment decisions of insurance companies, and evaluates the extent to which variations in these investors' financial conditions due to their operations affect the management of their financial portfolios. 
We consider a sample of 2,926 insurance companies from the U.S. between 2001 and 2015. Insurance companies are important institutional investors that have little control over the timing and the size of claims they must pay. P\&C insurers in particular can face large costs when weather-related or other disasters unexpectedly strike. We document that insurers' size and ratings are correlated with their portfolio allocation across different asset categories. Larger and better-rated insurers allocate more of their portfolios to riskier and more illiquid assets. We estimate the way in which operating losses affect P\&C insurers' portfolios. Our results suggest that following operating losses, insurers reduce their holdings in riskier corporate bonds. This finding also holds when we instrument for insurers' losses with weather damages, which can substantially affect insurers' claims. This result shows that exogenous shocks to insurers' financial strength lead insurers to lower the risk of their portfolios. Insurers with more financial flexibility can afford to take more portfolio risk and hence receive higher expected returns.

We also find that smaller or worse-rated insurers, whose financial conditions can be more negatively impacted by losses, shift more towards safer bonds following losses. The effect of losses on insurers' corporate bond portfolio is also larger during the 2008 Financial Crisis. These results suggest that insurers have stronger risk-management incentives when they become more financially constrained. As argued by Froot, Scharfstein, and Stein (1993), risk management incentives can become stronger because of the costs of financial constraints.

Since insurers are regulated, the observed change in portfolios following losses could potentially occur because of regulatory pressure. We control econometrically for the regulatory effects of security choices within an asset class. We also restrict our analysis to insurers that purchase bonds rated worse than A- and study their investment in bonds rated A- or better. Our results on how losses affect insurers' corporate bond portfolios hold. It is unlikely that regulators restrict insurers' choices among bonds rated A- or better when insurers are allowed to purchase bonds rated worse than A-. Overall, our evidence suggests that insurers' shift towards safer bonds following losses occurs at least partially because of voluntary responses and not merely due to regulatory pressure. 
Institutional investors who are not delegated money managers are some of the most important investors in the economy. However, we do not know much about the way in which they make their investment choices. Theory is not clear on the source of these investors' preferences. By studying insurance companies' portfolio strategies, we hope to understand the decisions of these important investors, and also the considerations affecting portfolio decisions of institutional investors more broadly.

Our results suggest that more constrained insurance companies prefer safer portfolio choices, plausibly because the increased cost of financial distress exacerbates the downside risk of any investment. The amount of risk they are willing to take is a function of their financial conditions. The desire to maintain financial flexibility appears to lead insurers to forego higher expected returns to obtain less risk and greater liquidity in their portfolios.

This study raises a number of questions. Given that there are costs associated with financial frictions that limit the ability of insurers to take more risky investments, can we identify the factors leading to these costs and can we quantify their magnitudes directly? Do other institutional investors take advantage of insurers' demand for different securities and adjust their portfolios based on the changing residual supply of available securities? How do macroeconomic conditions interact with changes in insurers' investment demands? In particular, does the quality of bonds demanded by insurers vary inversely with the business cycle, leading to the observed increase in the quality of bonds issued during downturns? Finally, and perhaps most importantly, to what extent are insurers typical of other institutional investors, and how general is the finding that access to capital markets is an important factor in institutional portfolio decisions? These and other related questions would be excellent topics for future research. 


\section{References}

Acharya, V.V. and Steffen, S., 2015. The "greatest" carry trade ever? Understanding eurozone bank risks. Journal of Financial Economics, 115(2), pp.215-236.

Almeida, H., Campello, M., Cunha, I. and Weisbach, M.S., 2014. Corporate liquidity management: A conceptual framework and survey. Annu. Rev. Financ. Econ., 6(1), pp.135-162.

Almeida, H., Campello, M. and Weisbach, M.S., 2004. The cash flow sensitivity of cash. The Journal of Finance, 59(4), pp.1777-1804.

Almeida, H., Campello, M. and Weisbach, M.S., 2011. Corporate financial and investment policies when future financing is not frictionless. Journal of Corporate Finance, 17(3), pp.675-693.

Ambrose, B., Cai, N., and Helwege, J., 2008. Forced Selling of Fallen Angels. Journal of Fixed Income 18, 72-85.

Andonov, A., Bauer, R.M. and Cremers, K.J., 2017. Pension fund asset allocation and liability discount rates. The Review of Financial Studies, 30(8), pp.2555-2595.

Andrade, G. and Kaplan, S.N., 1998. How costly is financial (not economic) distress? Evidence from highly leveraged transactions that became distressed. The journal of finance, 53(5), pp.1443-1493.

Becker, B. and Ivashina, V., 2015. Reaching for yield in the bond market. The Journal of Finance, 70(5), pp.1863-1902.

Becker, B., Opp, M.M. and Saidi, F., 2020. Regulatory Forbearance in the US Insurance Industry: The Effects of Eliminating Capital Requirements.

Black, L.K. and Hazelwood, L.N., 2013. The effect of TARP on bank risk-taking. Journal of Financial Stability, 9(4), pp. 790-803.

Campello, M., Graham, J.R. and Harvey, C.R., 2010. The real effects of financial constraints: Evidence from a financial crisis. Journal of financial Economics, 97(3), pp.470-487.

Caballero, R. and A. Krishnamurthy, 2008. Collective risk management in a flight to quality episode, The Journal of Finance, 63, pp. 2195-2230.

Calomiris, C.W. and Wilson, B., 2004. Bank capital and portfolio management: The 1930s "Capital Crunch" and the scramble to shed risk. The Journal of Business, 77(3), pp. 421-455.

Çelik, S. and Isaksson, M., 2014. Institutional investors and ownership engagement. OECD Journal: Financial Market Trends, 2013(2), pp. 93-114.

Chaderina, M., Muermann, A., and Scheuch, C., 2018. The Dark Side of Liquid Bonds in Fire Sales. Working paper.

Chen T., Kamiya, S., and Lou, P., 2019. Investors’ Financial Health and Municipal Bond Liquidity Risk. Working paper.

Chen, X., Sun, Z., Yao, T. and Yu, T., 2020. Does operating risk affect portfolio risk? Evidence from insurers' securities holding. Journal of Corporate Finance, 62, p.101579.

Chodorow-Reich, G., Ghent, A. and Haddad, V., 2018. Asset insulators (No. w24973). National Bureau of Economic Research.

Cortés, K., and Strahan, P., 2017. Tracing Out Capital Flows: How Financially Integrated Banks Respond to Natural Disasters. Journal of Financial Economics 125, 182-199.

Dick-Nielsen, J., Feldhütter, P. and Lando, D., 2012. Corporate bond liquidity before and after the onset of the subprime crisis. Journal of Financial Economics, 103(3), pp.471-492.

Dick-Nielsen, J., 2009. Liquidity biases in TRACE. The Journal of Fixed Income, 19(2), pp.43-55.

Drechsler, I., Drechsel, T., Marques-Ibanez, D. and Schnabl, P., 2016. Who borrows from the lender of last resort?. The Journal of Finance, 71(5), pp.1933-1974.

Duchin, R., Gilbert, T., Harford, J. and Hrdlicka, C., 2017. Precautionary savings with risky assets: When cash is not cash. The Journal of Finance, 72(2), pp. 793-852.

Duchin, R. and Sosyura, D., 2014. Safer ratios, riskier portfolios: Banks' response to government aid. Journal of Financial Economics, 113(1), pp. 1-28. 
Ellul, A., Jotikasthira, C. and Lundblad, C.T., 2011. Regulatory pressure and fire sales in the corporate bond market. Journal of Financial Economics, 101(3), pp.596-620.

Ellul, A., Jotikasthira, C., Lundblad, C.T. and Wang, Y., 2015. Is historical cost accounting a panacea? Market stress, incentive distortions, and gains trading. The Journal of Finance, 70(6), pp.2489-2538.

Ellul, A., Jotikasthira, C., Kartasheva, A.V., Lundblad, C.T. and Wagner, W., 2018. Insurers as asset managers and systemic risk. Kelley School of Business Research Paper, (18-4).

Epermanis, K. and Harrington, S.E., 2006. Market discipline in property/casualty insurance: Evidence from premium growth surrounding changes in financial strength ratings. Journal of Money, Credit and Banking, pp.1515-1544.

Eisdorfer, A., 2008. Empirical evidence of risk shifting in financially distressed firms. The Journal of Finance, 63(2), pp.609-637.

Erel, I., Julio, B., Kim, W., and Weisbach, M.S. 2012. Macroeconomic Conditions and Capital Raising. Review of Financial Studies, 25, pp. 341-376.

Fama, E.F. and Jensen, M.C., 1983. Agency problems and residual claims. The Journal of Law and Economics, 26(2), pp.327-349.

Froot, K.A., Scharfstein, D.S. and Stein, J.C., 1993. Risk management: Coordinating corporate investment and financing policies. Journal of Finance, 48(5), pp.1629-1658.

Ge, S., 2020. How Do Financial Constraints Affect Product Pricing? Evidence from Weather and Life Insurance Premiums. New York University Working Paper.

Getmansky, M., Girardi, G., Hanley, K.W., Nikolova, S. and Pelizzon, L., 2016. Portfolio similarity and asset liquidation in the insurance industry. In Fourth Annual Conference on Financial Market Regulation.

Gilje, E.P., 2016. Do firms engage in risk-shifting? Empirical evidence. The Review of Financial Studies, 29(11), pp. 2925-2954.

Greenwood, R.M. and Vissing-Jorgensen, A., 2018. The impact of pensions and insurance on global yield curves. Harvard Business School Finance Working Paper, (18-109).

Hadlock, C.J. and Pierce, J.R., 2010. New evidence on measuring financial constraints: Moving beyond the KZ index. The Review of Financial Studies, 23(5), pp.1909-1940.

Hovakimian, A. and Kane, E.J., 2000. Effectiveness of capital regulation at U.S. commercial banks, 1985 to 1994. the Journal of Finance, 55(1), pp.451-468.

He, Z. and Krishnamurthy, A., 2012. A model of capital and crises. The Review of Economic Studies, 79(2) pp. 735-777.

He, Z. and Krishnamurthy, A., 2013. Intermediary asset pricing. American Economic Review 103(2) pp. 732-770.

He, Z. and Krishnamurthy, A., 2018. Intermediary asset pricing and the financial crisis, Annual Review of Finance Economics 10, pp. 173-197.

Huang, J.Z., Sun, Z., Yao, T. and Yu, T., 2018. Liquidity premium in the eye of the beholder: An analysis of the clientele effect in the corporate bond market, forthcoming Management Science.

Jensen, M.C. and Meckling, W.H., 1976. Theory of the firm: Managerial behavior, agency costs and ownership structure. Journal of Financial Economics, 3(4), pp. 305-360.

Kashyap, A.K. and Stein, J.C., 2000. What do a million observations on banks say about the transmission of monetary policy?. American Economic Review, 90(3), pp.407-428.

Keynes, John Maynard, 1936. The general theory of employment, interest and money, (McMillan: London).

Kirti, D., 2017. When gambling for resurrection is too risky. International Monetary Fund.

Koijen, R.S. and Yogo, M., 2019. A demand system approach to asset pricing. Journal of Political Economy, 127(4), pp.1475-1515.

Landier, A., Sraer, D.A. and Thesmar, D., 2015. The risk-shifting hypothesis: Evidence from subprime originations. MIT Working Paper.

Massa, M. and Zhang, L., 2020. The spillover effects of Hurricane Katrina on corporate bonds and the choice between bank and bond financing. Journal of Financial and Quantitative Analysis, pp.1-57. 
Mayers, D. and Smith Jr, C.W., 1986. Ownership structure and control: The mutualization of stock life insurance companies. Journal of Financial Economics, 16(1), pp. 73-98.

Markowitz, H., 1952. Portfolio selection. The Journal of Finance, 7(1), pp. 77-91.

Merrill, C.B., Nadauld, T., Stulz, R.M. and Sherlund, S.M., 2014. Were there fire sales in the RMBS market?. Charles A. Dice Center Working Paper, (2014-09).

Mohan, N. and Zhang, T., 2014. An analysis of risk-taking behavior for public defined benefit pension plans. Journal of Banking \& Finance, 40, pp.403-419.

Murray, S. and Nikolova, S., 2019, May. The bond pricing implications of rating-based capital requirements. In 14th Annual Mid-Atlantic Research Conference in Finance (MARC).

NAIC (National Association of Insurance Commissioners), 2015a. Risk-based capital forecasting and instructions, Property and casualty.

NAIC (National Association of Insurance Commissioners), 2015b. Risk-based capital forecasting and instructions, Life.

Nanda, V., Wu, W., and Zhou, X., 2019. Investment Commonality across Insurance Companies: Fire Sale Risk and Corporate Yield Spreads. Journal of Financial and Quantitative Analysis 54, 2543-2574.

O'Hara, M., Wang, Y. and Zhou, X.A., 2018. The execution quality of corporate bonds. Journal of Financial Economics, 130(2), pp.308-326.

Opler, Tim, Lee Pinkowitz, René M. Stulz, and Rohan Williamson, 1999. The Determinants and Implications of Corporate Cash Holdings. Journal of Financial Economics, 52, 3-46.

Parrino, R. and Weisbach, M.S., 1999. Measuring investment distortions arising from stockholderbondholder conflicts. Journal of Financial Economics, 53(1), pp. 3-42.

Rampini, A.A., Sufi, A. and Viswanathan, S., 2014. Dynamic risk management. Journal of Financial Economics, 111(2), pp.271-296.

Rauh, J.D., 2009. Risk shifting versus risk-management: investment policy in corporate pension plans. Review of Financial Studies, 22(7), pp. 2687-2733.

Schüwer, U., Lambert, C., and Noth, F., 2019. How Do Banks React to Catastrophic Events? Evidence from Hurricane Katrina. Review of Finance 23, 75-116.

Sen, I., 2018, Regulatory limits to risk management. London Business School Working Paper.

Sen, I. and Sharma, V., 2020, Internal models, make believe prices, and bond market cornering. Harvard Business School Working Paper.

Smith, C.W. and Stulz, R.M., 1985. The determinants of firms' hedging policies. Journal of Financial and Quantitative Analysis, 20(4), pp. 391-405.

Vayanos, D. 2004. Flight to quality, flight to liquidity, and the pricing of risk, NBER Working Paper 10327. 


\section{Figure 1: Effect of Losses on Insurers’ Holdings of Riskier vs. Safer Bonds, Lead-Lag Plot}

Figure 1 plots the estimates of coefficients, $\alpha_{n}$, and their corresponding 95\% confidence interval from estimating the following specification. Holding of Bond $d_{i, j, q}=\sum_{n=-5}^{10} \alpha_{n} * \operatorname{Loss}_{i, q-n} *$ Bond Worse-rated $_{j, q-1}+\sum_{n=-5}^{10} \beta_{n} * \operatorname{Loss}_{i, q-n} *$ Other Bond Char B $_{j, q-1}+\gamma *$ Financial $_{i, q-11} *$ All Bond $\operatorname{Char}_{j, q-1}+F E_{i, q}+F E_{j, q}+e_{i, j, q}$, where $n$ does not equal zero. When $n$ is between 1 and 10 , the losses precede insurers' holdings, and the estimated coefficient, $\alpha_{n}$, reflects how losses in quarter $q$ affect insurers' holdings of riskier versus safer bonds in $q+n$. These coefficients are plotted to the right of the vertical line in Figure 1. For example, the estimate of $\alpha_{1}$ is the first point to the right of the vertical line, representing how insurers' losses in $q$ affect holdings of riskier versus safer bonds in $q+1$. When $n$ is between -5 and -1 , the estimated coefficient, $\alpha_{n}$, reflects how losses in quarter $q$ are related to insurers' holdings of riskier versus safer bonds before $q$. These coefficients are plotted to the left of the vertical line in Figure 1. The dependent variable is $\mathrm{P} \& \mathrm{C}$ insurer $i$ 's holdings of a specific corporate bond $j$, as a percentage of the total market value of all the corporate bonds insurer $i$ holds. Other Bond Char is a vector of bond characteristics, including coupon rate, maturity, illiquidity, and whether the bond was downgraded in q-1. All Bond Char includes these variables and Bond Worse-Rated. We only use bonds in the NAIC 1 category. Financial is a vector of insurers' financial variables, including insurers' log assets, insurers' ratings, leverage, $\mathrm{RBC}$ ratio, all of which are from quarter $q-11$, except $\mathrm{RBC}$ ratio. RBC ratio is only available annually, so we use the RBC ratio from four years prior to the holding quarter. Standard errors are corrected for clustering at the bond CUSIP-year-quarter level. The solid line connects the estimates of $\alpha_{n}$. The dashed line plots the $95 \%$ confidence interval.

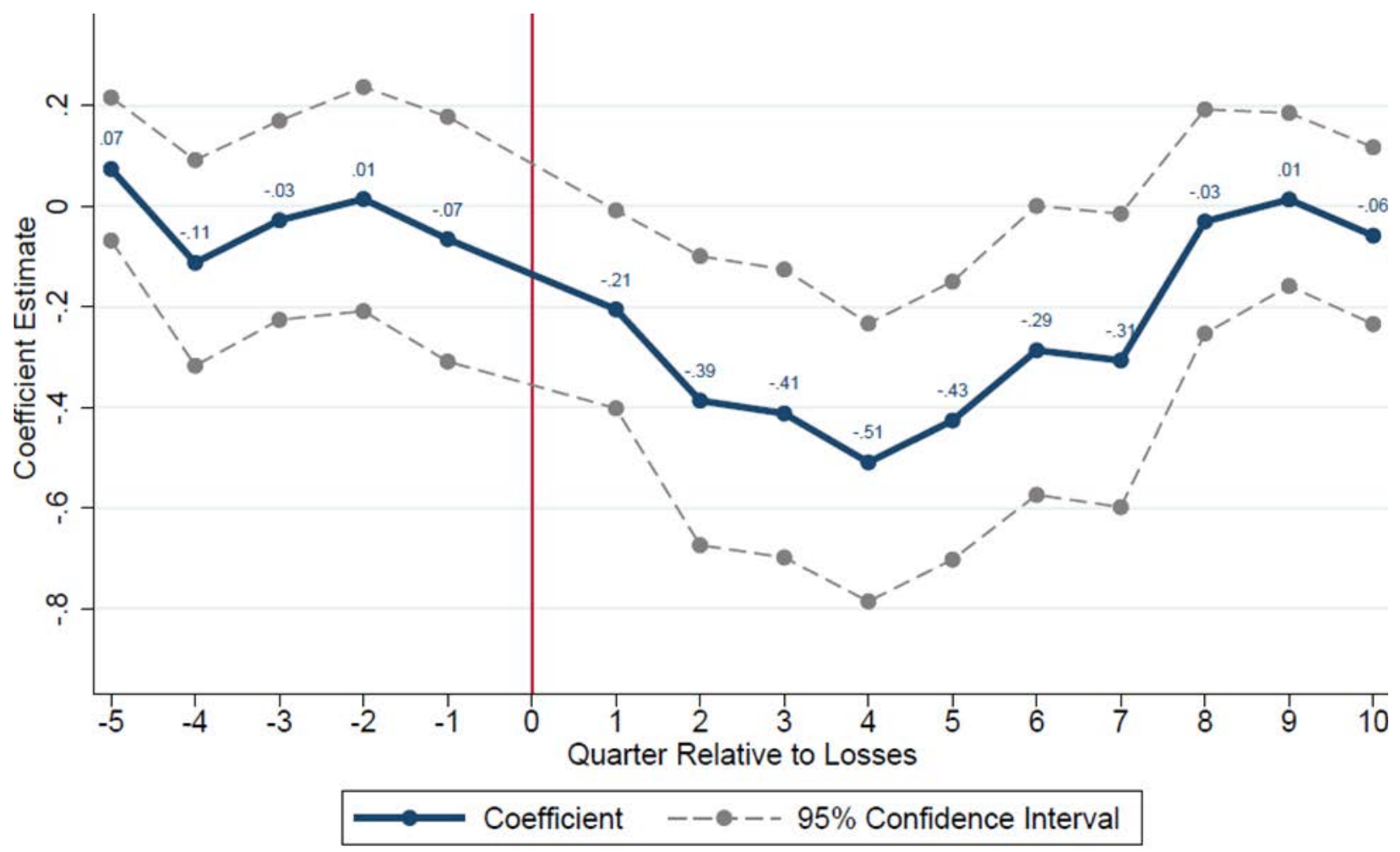




\section{Table 1: RBC Risk Charge for Different Securities}

This table presents the regulatory risk capital charge used in the calculation of RBC ratio, associated with different categories of securities, for P\&C and life insurers, respectively. See Becker, Opp, and Saidi (2020) for MBS.

\begin{tabular}{|c|c|c|c|c|}
\hline \multirow{2}{*}{ Security Type } & \multirow{2}{*}{ Credit Ratings } & \multirow{2}{*}{$\begin{array}{l}\text { NAIC Corporate } \\
\text { Bonds Category }\end{array}$} & \multicolumn{2}{|c|}{ Risk Charge } \\
\hline & & & P\&C & Life \\
\hline $\begin{array}{l}\text { U.S. Treasury Debt and Government Debt } \\
\text { (guaranteed and backed by the full faith } \\
\text { and credit of the U.S. government) }\end{array}$ & & NA & 0 & 0 \\
\hline Cash & & NA & $0.3 \%{ }^{18}$ & $0.4 \%^{19}$ \\
\hline $\begin{array}{l}\text { Bonds Issued by U.S. Government } \\
\text { Agencies (not backed by the U.S. } \\
\text { government) }{ }^{20}\end{array}$ & & NAIC 1 & $0.3 \%$ & $0.4 \%$ \\
\hline \multirow{6}{*}{ Corporate Bonds ${ }^{21} \&$ Municipal Bonds } & AAA, AA, A & NAIC 1 & $0.3 \%$ & $0.4 \%$ \\
\hline & BBB & NAIC 2 & $0.96 \%$ & $1.3 \%$ \\
\hline & $\mathrm{BB}$ & NAIC 3 & $3.39 \%$ & $4.6 \%$ \\
\hline & $\mathrm{B}$ & NAIC 4 & $7.38 \%$ & $10 \%$ \\
\hline & CCC & NAIC 5 & $16.96 \%$ & $23 \%$ \\
\hline & CC or below & NAIC 6 & $19.50 \%$ & $30 \%$ \\
\hline Unaffiliated Common Stock & & NA & $15 \%$ & $\begin{array}{l}22.5 \% \\
\quad \sim \\
45 \%^{22}\end{array}$ \\
\hline Other Long-Term Assets & & NA & & \\
\hline Real Estate & & NA & $10 \%$ & $\begin{array}{l}5 \% \sim \\
23 \%{ }^{23}\end{array}$ \\
\hline Mortgage Loans & & NA & $5 \%$ & $\begin{array}{l}3 \% \sim \\
20 \%\end{array}$ \\
\hline $\begin{array}{l}\text { Schedule BA (Private Equity, Hedge } \\
\text { Funds, etc.) }\end{array}$ & & NA & $20 \%$ & $30 \%{ }^{24}$ \\
\hline
\end{tabular}

${ }^{18}$ NAIC (2015a), P10.

19 NAIC (2015b), P41.

${ }^{20}$ Examples are FNMA and FHLMC collateralized mortgage obligations, see NAIC (2015a) P8.

${ }^{21}$ See Becker and Ivashina (2015), and Becker, Opp, and Saidi (2020).

${ }^{22}$ NAIC (2015b), P16: “30\% adjusted in the case of publicly traded stock by the weighted average beta for the portfolio of common stock, subject to a minimum factor of $22.5 \%$ and a maximum factor of $45 \%$."

${ }^{23}$ NAIC (2015b), P19.

${ }^{24}$ NAIC (2015b), P23. 


\section{Table 2: Summary Statistics}

This table presents summary statistics. Panel A offers statistics on insurers' financial variables and their holdings in major categories. Panel B offers statistics on corporate bonds in P\&C insurers' holdings at the CUSIP-insurer-quarter level. In Panel C, we sort insurers into tertiles based on lagged assets or insurer ratings, and report the averages of lagged financial variables and holdings in categories of each subsample. If the averages between the most two extreme subsamples are statistically different at the $5 \%$ level or lower, the numbers are displayed in bold.

\section{Panel A: Insurers’ Financials and Holdings in Major Categories}

\begin{tabular}{|c|c|c|c|c|c|c|}
\hline \multirow[t]{2}{*}{ Variable } & $\mathbf{N}$ & Mean & Std & 25 Pctl & Median & 75 Pctl \\
\hline & \multicolumn{6}{|c|}{ P\&C Insurers } \\
\hline \multicolumn{7}{|l|}{ Financial Variables } \\
\hline Asset (\$Billion) & 28866 & 0.44 & 1.31 & 0.02 & 0.06 & 0.24 \\
\hline Leverage (\%) & 28866 & 72.29 & 71.61 & 45.17 & 61.64 & 72.87 \\
\hline RBC Ratio & 27069 & 14.88 & 25.56 & 4.80 & 7.78 & 13.46 \\
\hline Rating (Larger=Worse) & 15972 & 3.99 & 2.48 & $3(\mathrm{~A})$ & $3(\mathrm{~A})$ & $4(\mathrm{~A}-)$ \\
\hline $\begin{array}{l}\text { Underwriting Loss (\% of } \\
\text { Lagged Assets), >=0 }\end{array}$ & 23096 & 2.35 & 4.64 & 0.00 & 0.00 & 2.69 \\
\hline $\begin{array}{l}\text { Underwriting Gain (\% of } \\
\text { Lagged Assets), >=0 }\end{array}$ & 23096 & 2.50 & 4.34 & 0.00 & 0.27 & 3.26 \\
\hline \multirow[t]{2}{*}{$\begin{array}{l}\text { Weather Exposure (\% of } \\
\text { Lagged Assets) }\end{array}$} & 19219 & 0.80 & 5.94 & -0.48 & -0.05 & 0.30 \\
\hline & \multicolumn{6}{|c|}{ Holdings in \% of Cash and Invested Assets } \\
\hline Cash & 28866 & 19.91 & 25.24 & 3.82 & 9.63 & 24.63 \\
\hline Treasury & 28866 & 10.61 & 16.17 & 0.35 & 4.06 & 13.38 \\
\hline U.S. Gov Agency & 28866 & 6.04 & 11.77 & 0.00 & 0.44 & 6.46 \\
\hline Muni Bond & 28866 & 20.75 & 23.84 & 0.00 & 11.61 & 34.95 \\
\hline MBS & 28866 & 10.13 & 13.15 & 0.00 & 4.02 & 16.94 \\
\hline Corp Bond & 28866 & 18.02 & 17.58 & 0.00 & 14.75 & 29.52 \\
\hline Public Stocks & 28866 & 5.43 & 10.62 & 0.00 & 0.00 & 6.43 \\
\hline \multirow[t]{2}{*}{ All Other } & 28866 & 8.97 & 13.36 & 0.00 & 3.22 & 12.38 \\
\hline & \multicolumn{6}{|c|}{ Life Insurers } \\
\hline \multicolumn{7}{|l|}{ Financial Variables } \\
\hline Asset (\$Billion) & 13110 & 4.68 & 16.19 & 0.02 & 0.12 & 1.29 \\
\hline Leverage (\%) & 13110 & 65.69 & 30.59 & 45.10 & 78.63 & 91.10 \\
\hline RBC Ratio & 12711 & 66.77 & 246.81 & 6.37 & 9.82 & 20.58 \\
\hline \multirow[t]{2}{*}{ Rating (Larger=Worse) } & 6663 & 4.24 & 2.75 & $2(\mathrm{~A}+)$ & $4(\mathrm{~A}-)$ & $5(\mathrm{~B}++)$ \\
\hline & \multicolumn{6}{|c|}{ Holdings in \% of Cash and Invested Assets } \\
\hline Cash & 13110 & 15.52 & 23.75 & 1.96 & 5.44 & 16.98 \\
\hline Treasury & 13110 & 9.21 & 17.45 & 0.15 & 1.82 & 8.92 \\
\hline U.S. Gov Agency & 13110 & 5.77 & 12.50 & 0.00 & 0.56 & 4.62 \\
\hline Muni Bond & 13110 & 5.70 & 11.38 & 0.00 & 0.62 & 5.46 \\
\hline MBS & 13110 & 13.12 & 14.22 & 0.01 & 9.63 & 21.00 \\
\hline Corp Bond & 13110 & 33.88 & 25.81 & 6.07 & 35.94 & 55.08 \\
\hline Public Stocks & 13110 & 1.88 & 5.38 & 0.00 & 0.00 & 0.44 \\
\hline All Other & 13110 & 14.26 & 18.22 & 0.81 & 8.03 & 20.70 \\
\hline
\end{tabular}


Panel B: Summary Statistics of P\&C Insurers’ Corporate Bond Holdings, CUSIP-Insurer-Quarter Level

\begin{tabular}{lcccccc}
\hline Variable & $\mathbf{N}$ & Mean & Std & 25 Pctl & Median & 75 Pctl \\
Mrkt Value*100/Cash \& Invested Assets & 1602118 & 0.31 & 0.44 & 0.05 & 0.16 & 0.39 \\
Mrkt Value*100/Mrkt Value of All Corp Bonds Held & 1602118 & 1.47 & 2.43 & 0.24 & 0.69 & 1.64 \\
Bond Rating & 1602118 & 7.18 & 2.89 & 5.50 & 7.00 & 9.00 \\
Years to Maturity & 1602118 & 5.73 & 5.11 & 2.58 & 4.58 & 7.58 \\
Coupon Rate & 1602118 & 5.20 & 1.78 & 4.25 & 5.35 & 6.25 \\
Downgraded Dummy & 1602118 & 0.08 & 0.26 & 0.00 & 0.00 & 0.00 \\
0-Trading Day (\%) & 1602118 & 28.49 & 29.20 & 1.64 & 17.46 & 50.82 \\
Imputed Round-trip Transct Cost*1000 & 1602118 & 5.49 & 3.72 & 2.86 & 4.52 & 7.05 \\
Dummy for NAIC Category $=1$ & 1602118 & 0.54 & 0.50 & 0.00 & 1.00 & 1.00 \\
Dummy for NAIC Category $=2$ & 1602118 & 0.36 & 0.48 & 0.00 & 0.00 & 1.00 \\
Dummy for NAIC Category $=3$ & 1602118 & 0.05 & 0.23 & 0.00 & 0.00 & 0.00 \\
Dummy for NAIC Category $=4$ & 1602118 & 0.04 & 0.20 & 0.00 & 0.00 & 0.00 \\
Dummy for NAIC Category $=5$ & 1602118 & 0.01 & 0.09 & 0.00 & 0.00 & 0.00 \\
Dummy for NAIC Category $=6$ & 1602118 & 0.00 & 0.04 & 0.00 & 0.00 & 0.00 \\
Offering Spread over Treasury & 705925 & 169.94 & 117.05 & 88.30 & 137.60 & 214.91 \\
\hline
\end{tabular}


Panel C: Insurers' Financials and Holdings in Categories across Subsamples of Insurers

\begin{tabular}{|c|c|c|c|c|c|c|c|c|c|c|c|c|c|}
\hline & \multirow[b]{2}{*}{$\begin{array}{c}\mathrm{N} \\
\text { (Firm-Year) }\end{array}$} & \multicolumn{4}{|c|}{ Financial Variables $(y-1)$} & \multicolumn{8}{|c|}{ Holdings in \% of Cash and Invested Assets (y) } \\
\hline & & $\begin{array}{c}\text { Assets } \\
\text { (\$Billion) }\end{array}$ & $\begin{array}{c}\text { Leverage } \\
(\%)\end{array}$ & $\begin{array}{l}\text { RBC } \\
\text { Ratio }\end{array}$ & $\begin{array}{c}\text { Rating } \\
\text { Larger }=\text { Worse }\end{array}$ & $\begin{array}{r}\text { Cash } \\
\times \mathrm{C} \text { Insur } \\
\end{array}$ & $\begin{array}{l}\text { Treasury } \\
\text { rs }\end{array}$ & $\begin{array}{l}\text { U.S. Gov } \\
\text { Agency }\end{array}$ & $\begin{array}{l}\text { Muni } \\
\text { Bond }\end{array}$ & MBS & $\begin{array}{l}\text { Corp } \\
\text { Bond }\end{array}$ & $\begin{array}{l}\text { Public } \\
\text { Stocks }\end{array}$ & $\begin{array}{c}\text { All } \\
\text { Other }\end{array}$ \\
\hline \multicolumn{14}{|c|}{ Sort by P\&C Insurers' Assets (y-1) } \\
\hline Largest & 9806 & 1.23 & 73.75 & 9.8 & 3.08 & 9.36 & 8.12 & 4.28 & 26.2 & 12.77 & 21.74 & 6.13 & 11.06 \\
\hline Middle & 9526 & $\mathbf{0 . 0 7}$ & 73.63 & 14.97 & 4.15 & 16.56 & 11.42 & 7.19 & 22.17 & 11.83 & 19.43 & 4.5 & 6.85 \\
\hline Smallest & 9534 & 0.01 & 69.47 & 20.48 & 5.69 & 34.11 & 12.35 & 6.72 & 13.69 & 5.71 & 12.82 & 5.63 & 8.63 \\
\hline \multicolumn{14}{|c|}{ Sort by P\&C Insurers' Rating (y-1) } \\
\hline Best & 8352 & 1.04 & 73.68 & 16.67 & 2.54 & 10.76 & 11.16 & 4.59 & 27.86 & 11.57 & 18.56 & 5.83 & 9.01 \\
\hline Middle & 3905 & 0.24 & 72.42 & 15.25 & 4.01 & 14.00 & 9.35 & 6.94 & 23.25 & 12.13 & 20.25 & 5.97 & 7.74 \\
\hline Worst & 3715 & 0.13 & 71.75 & 11.7 & 7.22 & 20.15 & 10.31 & 8.05 & 17.74 & 10.75 & 19.08 & 4.76 & 8.58 \\
\hline \multicolumn{14}{|c|}{ Life Insurers } \\
\hline \multicolumn{14}{|c|}{ Sort by Life Insurers' Assets (y-1) } \\
\hline Largest & 4450 & 13.61 & 87.07 & 10.21 & 2.93 & 4.16 & 3.07 & 2.70 & 3.95 & 16.04 & 49.62 & 0.94 & 19.48 \\
\hline Middle & 4325 & 0.18 & 69.36 & 24.96 & 4.63 & 10.39 & 7.64 & 6.46 & 7.41 & 15.72 & 36.14 & 2.15 & 13.27 \\
\hline Smallest & 4335 & 0.01 & 40.08 & 175.7 & 7.33 & 32.29 & 17.08 & 8.23 & 5.79 & 7.52 & 15.48 & 2.57 & 9.89 \\
\hline \multicolumn{14}{|c|}{ Sort by Life Insurers' Rating (y-1) } \\
\hline Best & 3069 & 15.17 & 81.43 & 17.45 & 2.32 & 5.78 & 4.33 & 2.39 & 4.35 & 15.09 & 49.72 & 1.14 & 17.12 \\
\hline Middle & 1838 & 1.58 & 71.64 & 21.56 & 4.33 & 9.30 & 7.18 & 6.61 & 8.07 & 16.31 & 39.8 & 1.13 & 11.44 \\
\hline Worst & 1756 & 0.63 & 66 & 30.17 & 7.52 & 15.32 & 9.89 & 7.69 & 7.51 & 13.64 & 32.12 & 1.8 & 11.64 \\
\hline
\end{tabular}


Table 3: P\&C Insurers' Operating Losses and Their Corporate Bond Holdings at CUSIP Level

The dependent variable is P\&C insurer $i$ 's holdings of a specific corporate bond $j$, as a percentage of $i$ 's cash and invested assets in quarter $q$ in Columns (1), (2), (5), and (6), or as a percentage of the total market value of all the corporate bonds insurer $i$ holds in quarter $q$ in the other columns.

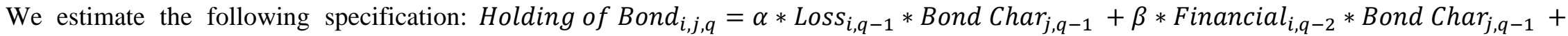
$F E_{i, q}+F E_{j, q}+e_{i, j, q}$. Bond Char includes Bond Worse-Rated, coupon rate, maturity, illiquidity, an indicator for whether the bond was downgraded in $q-1$, and an indicator for bonds in the NAIC 1 category. Financial is a vector including insurers' log assets, insurers' ratings, leverage, RBC ratio, all of which are from quarter $q-2$, except RBC ratio. RBC ratio is only available annually, so we use the RBC ratio from the year prior. Odd columns present OLS results, and even columns the second-stage results of the instrumental variable regressions. The first-stage results corresponding to Column (4) are reported in Table A.5. In each column, we control for bond CUSIP-Year-Quarter and insurance Firm-Year-Quarter fixed effects. Standard errors are corrected for clustering at the bond CUSIP-year-quarter level. ***, **, and * denote statistical significance at the $1 \%$, 5\%, and 10\% levels. See Table A.1 for variable definitions.

\begin{tabular}{|c|c|c|c|c|c|c|c|c|}
\hline \multirow{3}{*}{ Dependent Variable: } & \multicolumn{4}{|c|}{ NAIC Category $=1$} & \multicolumn{4}{|c|}{ NAIC Category $=1 \& 2$} \\
\hline & \multicolumn{2}{|c|}{$\begin{array}{c}\text { Mrkt Value }(\mathrm{i}, \mathrm{j}, \mathrm{q}) * 100 \\
\text { / Cash \& Invested } \\
\text { Assets }(\mathrm{i}, \mathrm{q}) \\
\end{array}$} & \multicolumn{2}{|c|}{$\begin{array}{l}\text { Mrkt Value }(\mathrm{i}, \mathrm{j}, \mathrm{q}) * 100 \\
\text { / Mrkt Value of All } \\
\text { Corp Bonds Held }(\mathrm{i}, \mathrm{q})\end{array}$} & \multicolumn{2}{|c|}{$\begin{array}{l}\text { Mrkt Value }(\mathrm{i}, \mathrm{j}, \mathrm{q}) * 100 \\
\text { / Cash \& Invested } \\
\text { Assets (i,q) }\end{array}$} & \multicolumn{2}{|c|}{$\begin{array}{l}\text { Mrkt Value (i,j,q) *100 } \\
\text { / Mrkt Value of All } \\
\text { Corp Bonds Held (i,q) }\end{array}$} \\
\hline & $\begin{array}{l}\text { OLS } \\
(1)\end{array}$ & $\begin{array}{l}\text { IV } \\
(2)\end{array}$ & $\begin{array}{c}\text { OLS } \\
(3)\end{array}$ & $\begin{array}{l}\text { IV } \\
(4)\end{array}$ & $\begin{array}{c}\text { OLS } \\
(5)\end{array}$ & $\begin{array}{l}\text { IV } \\
(6)\end{array}$ & $\begin{array}{c}\text { OLS } \\
(7) \\
\end{array}$ & $\begin{array}{l}\text { IV } \\
(8)\end{array}$ \\
\hline Loss (q-1)*Bond Worse-Rated (q-1) & $\begin{array}{c}-0.1312^{* * *} \\
(-7.37)\end{array}$ & $\begin{array}{c}-0.1681^{* * *} \\
(-2.61)\end{array}$ & $\begin{array}{c}-0.4435^{* * *} \\
(-6.06)\end{array}$ & $\begin{array}{c}-0.7473^{* *} \\
(-1.99)\end{array}$ & $\begin{array}{c}-0.1088^{* * *} \\
(-7.32)\end{array}$ & $\begin{array}{c}-0.1515^{* * *} \\
(-2.70)\end{array}$ & $\begin{array}{c}-0.3361^{* * *} \\
(-5.44)\end{array}$ & $\begin{array}{c}-0.6131^{* *} \\
(-2.21)\end{array}$ \\
\hline Loss (q-1)*Bond Coupon Rate & $\begin{array}{c}0.0130 \\
(0.91)\end{array}$ & $\begin{array}{c}-0.0332 \\
(-0.41)\end{array}$ & $\begin{array}{c}0.1244^{* *} \\
(2.02)\end{array}$ & $\begin{array}{c}0.7857 * * \\
(2.11)\end{array}$ & $\begin{array}{c}-0.0118 \\
(-1.13)\end{array}$ & $\begin{array}{c}-0.0171 \\
(-0.28)\end{array}$ & $\begin{array}{c}-0.0090 \\
(-0.20)\end{array}$ & $\begin{array}{c}0.3714 \\
(1.43)\end{array}$ \\
\hline Loss (q-1)*Bond Maturity (q) & $\begin{array}{c}0.0000 \\
(0.76)\end{array}$ & $\begin{array}{c}0.0019 \\
(0.47)\end{array}$ & $\begin{array}{c}0.0002 \\
(0.66)\end{array}$ & $\begin{array}{c}0.0329 \\
(0.46)\end{array}$ & $\begin{array}{c}-0.1511 \\
(-0.83)\end{array}$ & $\begin{array}{c}0.9292 \\
(0.83)\end{array}$ & $\begin{array}{c}-0.5343 \\
(-0.65)\end{array}$ & $\begin{array}{c}13.8909 \\
(0.79)\end{array}$ \\
\hline Loss (q-1)*Bond Illiquidity (q-1) & $\begin{array}{l}0.0089 \\
(0.13)\end{array}$ & $\begin{array}{c}0.3566 \\
(1.07)\end{array}$ & $\begin{array}{c}0.3828 \\
(1.26)\end{array}$ & $\begin{array}{l}1.2039 \\
(0.77)\end{array}$ & $\begin{array}{c}-0.0074 \\
(-0.14)\end{array}$ & $\begin{array}{c}0.1854 \\
(0.73)\end{array}$ & $\begin{array}{c}0.2841 \\
(1.27)\end{array}$ & $\begin{array}{l}0.7119 \\
(0.72)\end{array}$ \\
\hline Loss (q-1)*Bond Downgraded Dummy (q-1) & $\begin{array}{c}-0.1254^{*} \\
(-1.71)\end{array}$ & $\begin{array}{c}-0.3914 \\
(-0.98)\end{array}$ & $\begin{array}{c}-0.5531^{*} \\
(-1.70)\end{array}$ & $\begin{array}{c}-1.1858 \\
(-0.55)\end{array}$ & $\begin{array}{c}-0.1192 * * \\
(-2.13)\end{array}$ & $\begin{array}{c}-0.0841 \\
(-0.27)\end{array}$ & $\begin{array}{c}-0.4472 * \\
(-1.81)\end{array}$ & $\begin{array}{c}0.1961 \\
(0.12)\end{array}$ \\
\hline Loss (q-1)*Bond NAIC 1 Dummy (q-1) & & & & & $\begin{array}{c}0.4935 * * * \\
(6.76)\end{array}$ & $\begin{array}{c}0.7454^{* *} \\
(2.56)\end{array}$ & $\begin{array}{c}1.3595 * * * \\
(4.46)\end{array}$ & $\begin{array}{c}3.3970^{* *} \\
(2.47)\end{array}$ \\
\hline
\end{tabular}




\begin{tabular}{|c|c|c|c|c|c|c|c|c|}
\hline & $(1)$ & $(2)$ & $(3)$ & (4) & (5) & $(6)$ & $(7)$ & $(8)$ \\
\hline Log Assets (q-2)*Bond Worse-Rated (q-1) & $\begin{array}{c}0.0034 * * * \\
(20.97)\end{array}$ & $\begin{array}{c}0.0034 * * * \\
(20.38)\end{array}$ & $\begin{array}{c}0.0128 * * * \\
(16.54)\end{array}$ & $\begin{array}{c}0.0124 * * * \\
(13.97)\end{array}$ & $\begin{array}{c}0.0035^{* * *} \\
(24.03)\end{array}$ & $\begin{array}{c}0.0034^{* * *} \\
(23.56)\end{array}$ & $\begin{array}{c}0.0121 * * * \\
(17.68)\end{array}$ & $\begin{array}{c}0.0118 * * * \\
(17.23)\end{array}$ \\
\hline Log Assets (q-2)*Bond Coupon Rate & $\begin{array}{c}-0.0031^{* * *} \\
(-18.84)\end{array}$ & $\begin{array}{c}-0.0030 * * * \\
(-17.04)\end{array}$ & $\begin{array}{c}-0.0109 * * * \\
(-14.69)\end{array}$ & $\begin{array}{c}-0.0099 * * * \\
(-7.65)\end{array}$ & $\begin{array}{c}-0.0026 * * * \\
(-20.71)\end{array}$ & $\begin{array}{c}-0.0025^{* * *} \\
(-19.78)\end{array}$ & $\begin{array}{c}-0.0093 * * * \\
(-16.43)\end{array}$ & $\begin{array}{c}-0.0090^{* * *} \\
(-15.45)\end{array}$ \\
\hline Log Assets (q-2)*Bond Maturity (q) & $\begin{array}{c}0.0045 \\
(1.39)\end{array}$ & $\begin{array}{c}-0.0265 \\
(-0.33)\end{array}$ & $\begin{array}{c}0.0811^{* * *} \\
(2.62)\end{array}$ & $\begin{array}{c}-0.4542 \\
(-0.32)\end{array}$ & $\begin{array}{c}0.0042 * * * \\
(3.03)\end{array}$ & $\begin{array}{c}0.0039 * * * \\
(2.77)\end{array}$ & $\begin{array}{c}0.0254 * * * \\
(2.89)\end{array}$ & $\begin{array}{c}0.0220 * * \\
(2.19)\end{array}$ \\
\hline Log Assets (q-2)*Bond Illiquidity (q-1) & $\begin{array}{c}0.0047 * * * \\
(5.99)\end{array}$ & $\begin{array}{c}0.0048 * * * \\
(5.87)\end{array}$ & $\begin{array}{c}0.0070 * \\
(1.92)\end{array}$ & $\begin{array}{c}0.0082^{*} \\
(1.68)\end{array}$ & $\begin{array}{c}0.0041^{* * *} \\
(6.92)\end{array}$ & $\begin{array}{c}0.0041^{* * *} \\
\quad(6.80)\end{array}$ & $\begin{array}{c}0.0095 * * * \\
(3.44)\end{array}$ & $\begin{array}{c}0.0094^{* * *} \\
(3.39)\end{array}$ \\
\hline Log Assets (q-2)*Bond Downgraded Dummy (q-1) & $\begin{array}{c}0.0038 * * * \\
(4.48)\end{array}$ & $\begin{array}{c}0.0037 * * * \\
(4.33)\end{array}$ & $\begin{array}{c}0.0193 * * * \\
(4.67)\end{array}$ & $\begin{array}{c}0.0190 * * * \\
(4.48)\end{array}$ & $\begin{array}{c}0.0024 * * * \\
(3.73)\end{array}$ & $\begin{array}{c}0.0024 * * * \\
(3.76)\end{array}$ & $\begin{array}{c}0.0133^{* * *} \\
(4.28)\end{array}$ & $\begin{array}{c}0.0139 * * * \\
(4.34)\end{array}$ \\
\hline Log Assets (q-2)*Bond NAIC 1 Dummy (q-1) & & & & & $\begin{array}{c}-0.0270 * * * \\
(-38.53)\end{array}$ & $\begin{array}{c}-0.0267 * * * \\
(-37.57)\end{array}$ & $\begin{array}{c}-0.0966 * * * \\
(-29.16)\end{array}$ & $\begin{array}{c}-0.0947 * * * \\
(-28.27)\end{array}$ \\
\hline $\begin{array}{l}\text { Insurer Rating (larger=worse) (q-2) } \\
\text { *Bond Worse-Rated (q-1) }\end{array}$ & $\begin{array}{c}-0.0015 * * * \\
(-6.84)\end{array}$ & $\begin{array}{c}-0.0015 * * * \\
(-6.20)\end{array}$ & $\begin{array}{c}-0.0086 * * * \\
(-8.16)\end{array}$ & $\begin{array}{c}-0.0082 * * * \\
(-6.99)\end{array}$ & $\begin{array}{c}-0.0011 * * * \\
(-5.37)\end{array}$ & $\begin{array}{c}-0.0010 * * * \\
(-4.83)\end{array}$ & $\begin{array}{c}-0.0068 * * * \\
(-7.28)\end{array}$ & $\begin{array}{c}-0.0065 * * * \\
(-6.36)\end{array}$ \\
\hline Insurer Rating $(\mathrm{q}-2) *$ Bond Coupon Rate & $\begin{array}{c}-0.0006 * * * \\
(-2.87)\end{array}$ & $\begin{array}{c}-0.0005^{* *} \\
(-2.04)\end{array}$ & $\begin{array}{c}-0.0020 * * \\
(-2.00)\end{array}$ & $\begin{array}{l}-0.0022 \\
(-1.46)\end{array}$ & $\begin{array}{c}-0.0004^{* *} \\
(-2.17)\end{array}$ & $\begin{array}{c}-0.0003 * \\
(-1.81)\end{array}$ & $\begin{array}{c}-0.0023 * * * \\
(-3.03)\end{array}$ & $\begin{array}{c}-0.0027 * * * \\
(-3.28)\end{array}$ \\
\hline Insurer Rating (q-2)*Bond Maturity (q) & $\begin{array}{l}-0.0010 \\
(-0.14)\end{array}$ & $\begin{array}{l}-0.1409 \\
(-0.47)\end{array}$ & $\begin{array}{l}-0.0287 \\
(-0.44)\end{array}$ & $\begin{array}{l}-2.4553 \\
(-0.47)\end{array}$ & $\begin{array}{c}0.0061 \\
(1.01)\end{array}$ & $\begin{array}{c}0.0043 \\
(0.66)\end{array}$ & $\begin{array}{l}0.0506 \\
(1.51)\end{array}$ & $\begin{array}{l}0.0270 \\
(0.61)\end{array}$ \\
\hline Insurer Rating (q-2)*Bond Illiquidity (q-1) & $\begin{array}{c}-0.0050 * * * \\
(-4.85)\end{array}$ & $\begin{array}{c}-0.0054 * * * \\
(-4.73)\end{array}$ & $\begin{array}{c}-0.0224 * * * \\
(-4.97)\end{array}$ & $\begin{array}{c}-0.0219 * * * \\
(-3.16)\end{array}$ & $\begin{array}{c}-0.0036 * * * \\
(-4.50)\end{array}$ & $\begin{array}{c}-0.0039 * * * \\
(-4.56)\end{array}$ & $\begin{array}{c}-0.0254 * * * \\
(-7.10)\end{array}$ & $\begin{array}{c}-0.0263 * * * \\
(-6.85)\end{array}$ \\
\hline Insurer Rating (q-2)*Bond Downgraded Dummy (q-1) & $\begin{array}{c}0.0005 \\
(0.47)\end{array}$ & $\begin{array}{c}0.0009 \\
(0.72)\end{array}$ & $\begin{array}{c}0.0088^{*} \\
(1.85)\end{array}$ & $\begin{array}{c}0.0091 \\
(1.54)\end{array}$ & $\begin{array}{c}0.0003 \\
(0.42)\end{array}$ & $\begin{array}{c}0.0003 \\
(0.37)\end{array}$ & $\begin{array}{c}0.0076^{* *} \\
(2.07)\end{array}$ & $\begin{array}{c}0.0069 \\
(1.59)\end{array}$ \\
\hline Insurer Rating (q-2)*Bond NAIC 1 Dummy (q-1) & & & & & $\begin{array}{c}0.0065 * * * \\
(6.50)\end{array}$ & $\begin{array}{c}0.0064^{* * *} \\
(5.89)\end{array}$ & $\begin{array}{c}0.0398 * * * \\
(8.72)\end{array}$ & $\begin{array}{c}0.0378 * * * \\
(7.58)\end{array}$ \\
\hline Leverage (q-2)*Bond Worse-Rated (q-1) & $\begin{array}{c}-0.0002 * * * \\
(-8.08)\end{array}$ & $\begin{array}{c}-0.0002 * * * \\
(-7.83)\end{array}$ & $\begin{array}{c}-0.0000 \\
(-0.02)\end{array}$ & $\begin{array}{c}0.0000 \\
(0.08)\end{array}$ & $\begin{array}{c}-0.0001 * * * \\
(-6.76)\end{array}$ & $\begin{array}{c}-0.0001 * * * \\
(-6.50)\end{array}$ & $\begin{array}{c}0.0001 \\
(0.72)\end{array}$ & $\begin{array}{c}0.0001 \\
(0.89)\end{array}$ \\
\hline Leverage (q-2)*Bond Coupon Rate & $\begin{array}{c}0.0002 * * * \\
(11.27)\end{array}$ & $\begin{array}{c}0.0002 * * * \\
(10.62)\end{array}$ & $\begin{array}{c}0.0008 * * * \\
(7.78)\end{array}$ & $\begin{array}{c}0.0007 * * * \\
(5.83)\end{array}$ & $\begin{array}{c}0.0002 * * * \\
(13.66)\end{array}$ & $\begin{array}{c}0.0002 * * * \\
(13.21)\end{array}$ & $\begin{array}{c}0.0007 * * * \\
(9.95)\end{array}$ & $\begin{array}{c}0.0007 * * * \\
(9.58)\end{array}$ \\
\hline Leverage (q-2)*Bond Maturity (q) & $\begin{array}{c}-0.0030 * \\
(-1.73)\end{array}$ & $\begin{array}{c}0.0131 \\
(0.38)\end{array}$ & $\begin{array}{c}-0.0217 * \\
(-1.82)\end{array}$ & $\begin{array}{c}0.2569 \\
(0.44)\end{array}$ & $\begin{array}{c}-0.0009 * * * \\
(-4.48)\end{array}$ & $\begin{array}{c}-0.0010 * * * \\
(-3.92)\end{array}$ & $\begin{array}{c}-0.0059 * * * \\
(-3.79)\end{array}$ & $\begin{array}{c}-0.0067 * * * \\
(-2.81)\end{array}$ \\
\hline
\end{tabular}

Table Continued on Next Page 


\begin{tabular}{|c|c|c|c|c|c|c|c|c|}
\hline & $(1)$ & $(2)$ & (3) & $(4)$ & (5) & $(6)$ & $(7)$ & $(8)$ \\
\hline Leverage (q-2)*Bond Illiquidity (q-1) & $\begin{array}{c}0.0001 \\
(0.74)\end{array}$ & $\begin{array}{c}0.0001 \\
(0.55)\end{array}$ & $\begin{array}{c}0.0006 \\
(1.13)\end{array}$ & $\begin{array}{c}0.0001 \\
(0.12)\end{array}$ & $\begin{array}{c}0.0002^{* *} \\
(2.25)\end{array}$ & $\begin{array}{c}0.0002^{* *} \\
(2.45)\end{array}$ & $\begin{array}{c}0.0004 \\
(1.22)\end{array}$ & $\begin{array}{c}0.0005 \\
(1.30)\end{array}$ \\
\hline Leverage (q-2)*Bond Downgraded Dummy (q-1) & $\begin{array}{l}-0.0000 \\
(-0.47)\end{array}$ & $\begin{array}{l}-0.0000 \\
(-0.36)\end{array}$ & $\begin{array}{c}-0.0011^{* *} \\
(-2.20)\end{array}$ & $\begin{array}{c}-0.0010^{*} \\
(-1.77)\end{array}$ & $\begin{array}{c}0.0000 \\
(0.35)\end{array}$ & $\begin{array}{c}0.0000 \\
(0.32)\end{array}$ & $\begin{array}{l}-0.0006 \\
(-1.58)\end{array}$ & $\begin{array}{l}-0.0006 \\
(-1.61)\end{array}$ \\
\hline Leverage (q-2)*Bond NAIC 1 Dummy (q-1) & & & & & $\begin{array}{c}0.0007 * * * \\
(7.76)\end{array}$ & $\begin{array}{c}0.0007 * * * \\
(7.41)\end{array}$ & $\begin{array}{c}-0.0004 \\
(-0.90)\end{array}$ & $\begin{array}{c}-0.0005 \\
(-1.12)\end{array}$ \\
\hline RBC Ratio (y-1)*Bond Worse-Rated (q-1) & $\begin{array}{c}-0.0001 * * * \\
(-7.39)\end{array}$ & $\begin{array}{c}-0.0001^{* * *} \\
(-7.40)\end{array}$ & $\begin{array}{c}-0.0007 * * * \\
(-6.29)\end{array}$ & $\begin{array}{c}-0.0007 * * * \\
(-5.92)\end{array}$ & $\begin{array}{c}-0.0001 * * * \\
(-6.20)\end{array}$ & $\begin{array}{c}-0.0001 * * * \\
(-6.19)\end{array}$ & $\begin{array}{c}-0.0005 * * * \\
(-5.64)\end{array}$ & $\begin{array}{c}-0.0005^{* * *} \\
(-5.65)\end{array}$ \\
\hline RBC Ratio $(y-1) *$ Bond Coupon Rate & $\begin{array}{l}0.0001^{* * * *} \\
\quad(6.39)\end{array}$ & $\begin{array}{c}0.0001^{* * *} \\
(5.32)\end{array}$ & $\begin{array}{c}0.0006 * * * \\
(6.08)\end{array}$ & $\begin{array}{c}0.0007 * * * \\
(2.74)\end{array}$ & $\begin{array}{c}0.0001 * * * \\
(7.56)\end{array}$ & $\begin{array}{c}0.0001^{* * *} \\
(7.48)\end{array}$ & $\begin{array}{c}0.0006 * * * \\
(7.38)\end{array}$ & $\begin{array}{c}0.0006 * * * \\
(7.39)\end{array}$ \\
\hline RBC Ratio (y-1)*Bond Maturity (q) & $\begin{array}{l}-0.0067 \\
(-1.50)\end{array}$ & $\begin{array}{c}-0.0300 \\
(-0.67)\end{array}$ & $\begin{array}{c}-0.0413 \\
(-1.37)\end{array}$ & $\begin{array}{c}-0.4460 \\
(-0.57)\end{array}$ & $\begin{array}{c}0.0000 \\
(0.18)\end{array}$ & $\begin{array}{c}0.0000 \\
(0.23)\end{array}$ & $\begin{array}{c}-0.0002 \\
(-0.58)\end{array}$ & $\begin{array}{c}-0.0002 \\
(-0.33)\end{array}$ \\
\hline RBC Ratio (y-1)*Bond Illiquidity (q-1) & $\begin{array}{c}0.0003^{* * *} \\
\quad(2.93)\end{array}$ & $\begin{array}{c}0.0003^{* * *} \\
(2.93)\end{array}$ & $\begin{array}{c}0.0015^{* * *} \\
(3.14)\end{array}$ & $\begin{array}{c}0.0017^{* *} \\
(2.28)\end{array}$ & $\begin{array}{c}0.0002^{* *} \\
(2.41)\end{array}$ & $\begin{array}{c}0.0002 * * \\
(2.45)\end{array}$ & $\begin{array}{c}0.0008^{* *} \\
(2.28)\end{array}$ & $\begin{array}{c}0.0008^{* *} \\
(2.27)\end{array}$ \\
\hline RBC Ratio (y-1)*Bond Downgraded Dummy (q-1) & $\begin{array}{c}-0.0000 \\
(-0.49)\end{array}$ & $\begin{array}{l}-0.0000 \\
(-0.49)\end{array}$ & $\begin{array}{c}-0.0000 \\
(-0.06)\end{array}$ & $\begin{array}{c}-0.0000 \\
(-0.09)\end{array}$ & $\begin{array}{c}-0.0001 * \\
(-1.71)\end{array}$ & $\begin{array}{c}-0.0001 * \\
(-1.68)\end{array}$ & $\begin{array}{c}-0.0006 \\
(-1.53)\end{array}$ & $\begin{array}{c}-0.0006 \\
(-1.49)\end{array}$ \\
\hline RBC Ratio (y-1)*Bond NAIC 1 Dummy (q-1) & & & & & $\begin{array}{c}0.0007 * * * \\
(9.13)\end{array}$ & $\begin{array}{c}0.0007 * * * \\
(9.11)\end{array}$ & $\begin{array}{c}0.0033^{* * *} \\
(7.06)\end{array}$ & $\begin{array}{c}0.0033^{* * * *} \\
\quad(7.08)\end{array}$ \\
\hline CUSIP-Year-Quarter FE & Yes & Yes & Yes & Yes & Yes & Yes & Yes & Yes \\
\hline Firm-Year-Quarter FE & Yes & Yes & Yes & Yes & Yes & Yes & Yes & Yes \\
\hline Cluster SE by CUSIP-Year-Quarter & Yes & Yes & Yes & Yes & Yes & Yes & Yes & Yes \\
\hline $\mathrm{N}$ & 848671 & 848218 & 849175 & 848722 & 1418688 & 1417926 & 1419495 & 1418733 \\
\hline Cragg-Donald Wald F statistic & & 145.787 & & 144.568 & & 1290.103 & & 1323.616 \\
\hline
\end{tabular}




\section{Table 4: Heterogeneous Effect of Losses on Insurers’ Corporate Bond Holdings}

The dependent variable is the market value of bond $j$ in P\&C insurer $i$ 's portfolio at the end of quarter $q$, as a percentage insurer $i$ 's cash and invested assets in quarter $q$. Panel A presents results estimating the

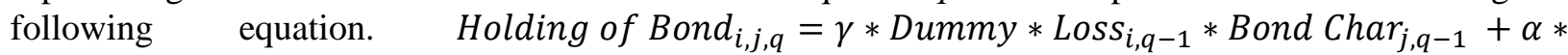
Loss $_{i, q-1} *$ Bond Char $_{j, q-1}+\beta *$ Financial $_{i, q-2} *$ Bond Char $_{j, q-1}+\lambda *$ Dummy $^{*}$ Bond Char $_{j, q-1}+F E_{i, q}+F E_{j, q}+e_{i, j, q}$. In Columns (1) and (2), Dummy is Insurer Small Dummy, which equals one if the insurer is smaller than the median in quarter $q$-2. In Columns (3) and (4), Dummy is Insurer Worse Rated Dummy, which equals one if the insurer's rating is worse than the median in quarter $q-2$. In Columns (5) and (6), Dummy is the Crisis Dummy, which equals one for 2008 and 2009 and zero otherwise. Bond Char is a vector of bond characteristics included in Table 3. Financial is a vector of insurers' financial variables included in Table 3. In Panel B, we replace the Dummy variable in the equation above with $R B C$ Related Measure. This measure is a dummy variable that equals one if the RBC ratio at the end of year $y$ 1 is lower than 2 in (1)-(2), lower than 5 in (3)-(4), lower than the median in year $y-1$ in (5)-(6) and the continuous variable RBC ratio at the end of $y-1$ in (7)-(8). In both panels, Bond Characteristics include Bond Worse-Rated, coupon rate, maturity, illiquidity, whether the bond was downgraded in $q-1$, and a dummy variable indicating whether the bond is in the NAIC 1 category. Financial is a vector including insurers' log assets, insurers' ratings, leverage, RBC ratio, all of which are from quarter $q-2$, except RBC ratio. $\mathrm{RBC}$ ratio is only available annually, so we use the $\mathrm{RBC}$ ratio from the year prior. Controls include interaction terms between each of insurers' financials (assets, rating, leverage, and RBC ratio) and bond characteristics, i.e., all the independent variables used for estimation for Table 3, except the interaction term between insurer size and bond characteristics in Columns (1)-(2) of Panel A, between insurer rating and bond characteristics in Columns (3)-(4) of Panel A, and insurer RBC ratio and bond characteristics in Columns (1)-(6) in Panel B. Odd-numbered columns only use bonds in the NAIC 1 category and evennumbered columns use bonds in both NAIC 1 and 2 categories, and include NAIC 1 Dummy among Bond Characteristics. Panel C repeats Columns (1) and (5) of Table 3 using subsamples. The subsamples correspond to the dummy variables used in Panels A and B. We estimate Equation (1):

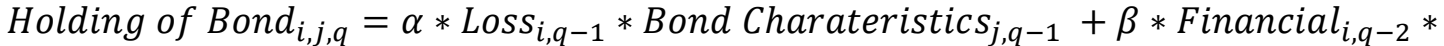
Bond Charateristics $s_{j, q-1}+F E_{i, q}+F E_{j, q}+e_{i, j, q}$. Panel C reports the coefficients on Loss (q-1)*Bond Worse-Rated (q-1) for different subsamples. Controls include all those in Table 3. Standard errors are corrected for clustering at the bond CUSIP-year-quarter level. ***, **, and * denote statistical significance at the $1 \%, 5 \%$, and $10 \%$ levels. See Table A.1 for variable definitions. 
Panel A: Insurer Size, Insurer Rating, the 2008 Financial Crisis, and the Effect of Losses on Corporate Bond Investments

\begin{tabular}{|c|c|c|c|c|c|c|}
\hline & \multicolumn{6}{|c|}{ Mrkt Value (i,j,q) *100 / Cash \& Invested Assets (i,q) } \\
\hline Dummy: & \multicolumn{2}{|c|}{$\begin{array}{c}\text { Insurer Small Dummy } \\
(\mathrm{q}-2)\end{array}$} & \multicolumn{2}{|c|}{$\begin{array}{l}\text { Insurer Worse Rated } \\
\text { Dummy (q-2) }\end{array}$} & \multicolumn{2}{|c|}{$\begin{array}{c}\text { Crisis (2008-2009) } \\
\text { Dummy }\end{array}$} \\
\hline & $\begin{array}{c}1 \\
(1)\end{array}$ & $\begin{array}{c}1 \& 2 \\
(2)\end{array}$ & $\begin{array}{c}1 \\
(3)\end{array}$ & $\begin{array}{c}1 \& 2 \\
(4)\end{array}$ & $\begin{array}{c}1 \\
(5)\end{array}$ & $\begin{array}{c}1 \& 2 \\
(6)\end{array}$ \\
\hline Dummy*Loss (q-1)*Bond Worse-Rated (q-1) & $\begin{array}{c}-0.0932 * * * \\
(-2.70)\end{array}$ & $\begin{array}{c}-0.0790 * * * \\
(-2.84)\end{array}$ & $\begin{array}{c}-0.0972 * * * \\
(-3.06)\end{array}$ & $\begin{array}{c}-0.1216^{* * *} \\
(-4.79)\end{array}$ & $\begin{array}{c}-0.0886 * * \\
(-1.98)\end{array}$ & $\begin{array}{c}-0.0906 * * \\
(-2.29)\end{array}$ \\
\hline Loss $(\mathrm{q}-1) *$ Bond Worse-Rated (q-1) & $\begin{array}{c}-0.0717^{* * * *} \\
(-2.65)\end{array}$ & $\begin{array}{c}-0.0601 * * * \\
(-2.90)\end{array}$ & $\begin{array}{c}-0.0742 * * * \\
(-3.05)\end{array}$ & $\begin{array}{l}-0.0264 \\
(-1.44)\end{array}$ & $\begin{array}{c}-0.1088^{* * *} \\
(-5.63)\end{array}$ & $\begin{array}{c}-0.0882 * * * \\
(-5.60)\end{array}$ \\
\hline Dummy*Bond Worse-Rated (q-1) & $\begin{array}{c}-0.0100 * * * \\
(-18.41)\end{array}$ & $\begin{array}{c}-0.0101 * * * \\
(-21.22)\end{array}$ & $\begin{array}{c}-0.0037 * * * \\
(-6.51)\end{array}$ & $\begin{array}{c}-0.0032 * * * \\
(-6.51)\end{array}$ & & \\
\hline Dummy*Loss (q-1)*Bond NAIC 1 Dummy (q-1) & & $\begin{array}{l}0.4855^{* * * *} \\
\quad(3.60)\end{array}$ & & $\begin{array}{c}0.7386 * * * \\
(5.88)\end{array}$ & & $\begin{array}{l}0.4178^{* *} \\
\quad(2.27)\end{array}$ \\
\hline Loss (q-1)*Bond NAIC 1 Dummy (q-1) & & $\begin{array}{c}0.2288^{* *} \\
(2.34)\end{array}$ & & $\begin{array}{c}0.0098 \\
(0.11)\end{array}$ & & $\begin{array}{l}0.3987 * * * \\
\quad(5.03)\end{array}$ \\
\hline Dummy*Bond NAIC 1 Dummy (q-1) & & $\begin{array}{l}0.0781^{* * *} \\
(33.20)\end{array}$ & & $\begin{array}{c}0.0192 * * * \\
(8.19)\end{array}$ & & \\
\hline Controls & Yes & Yes & Yes & Yes & Yes & Yes \\
\hline CUSIP-Year-Quarter FE & Yes & Yes & Yes & Yes & Yes & Yes \\
\hline Firm-Year-Quarter FE & Yes & Yes & Yes & Yes & Yes & Yes \\
\hline Cluster SE by CUSIP-Year-Quarter & Yes & Yes & Yes & Yes & Yes & Yes \\
\hline $\mathrm{N}$ & 848671 & 1418688 & 848671 & 1418688 & 848671 & 1418688 \\
\hline
\end{tabular}




\section{Panel B: Insurer RBC ratio, and the Effect of Losses on Corporate Bond Investments}

\begin{tabular}{|c|c|c|c|c|c|c|c|c|}
\hline \multirow{3}{*}{$\begin{array}{r}\text { Dependent Variable: } \\
\text { RBC-Related Measure: } \\
\text { NAIC Category: }\end{array}$} & \multicolumn{8}{|c|}{ Mrkt Value $(\mathrm{i}, \mathrm{j}, \mathrm{q}) * 100 /$ Cash \& Invested Assets (i,q) } \\
\hline & \multicolumn{2}{|c|}{$\begin{array}{c}\text { Dummy: RBC (y-1) } \\
<2\end{array}$} & \multicolumn{2}{|c|}{$\begin{array}{l}\text { Dummy: RBC (y-1) } \\
<5\end{array}$} & \multicolumn{2}{|c|}{$\begin{array}{l}\text { Dummy: RBC (y-1) } \\
<\text { Median }(y-1)\end{array}$} & \multicolumn{2}{|c|}{$\mathrm{RBC}(\mathrm{y}-1)$} \\
\hline & $\begin{array}{c}1 \\
(1)\end{array}$ & $\begin{array}{c}1 \& 2 \\
(2)\end{array}$ & $\begin{array}{c}1 \\
(3)\end{array}$ & $\begin{array}{c}1 \& 2 \\
(4)\end{array}$ & $\begin{array}{c}1 \\
(5)\end{array}$ & $\begin{array}{c}1 \& 2 \\
(6)\end{array}$ & $\begin{array}{c}1 \\
(7)\end{array}$ & $\begin{array}{c}1 \& 2 \\
(8)\end{array}$ \\
\hline $\begin{array}{l}\text { RBC-Related Measure } \\
* \text { Loss }(\mathrm{q}-1) * \text { Bond Worse-Rated (q-1) }\end{array}$ & $\begin{array}{c}-0.6263 * * \\
(-2.04)\end{array}$ & $\begin{array}{c}-0.2172 \\
(-0.82)\end{array}$ & $\begin{array}{c}-0.1066 * \\
(-1.66)\end{array}$ & $\begin{array}{l}-0.0491 \\
(-0.88)\end{array}$ & $\begin{array}{l}-0.0128 \\
(-0.24)\end{array}$ & $\begin{array}{c}-0.0406 \\
(-0.89)\end{array}$ & $\begin{array}{l}0.0021 \\
(0.86)\end{array}$ & $\begin{array}{c}-0.0009 \\
(-0.44)\end{array}$ \\
\hline Loss $(\mathrm{q}-1) *$ Bond Worse-Rated $(\mathrm{q}-1)$ & $\begin{array}{l}-0.2144^{* * *} \\
\quad(-7.60)\end{array}$ & $\begin{array}{c}-0.1980^{* * *} \\
(-8.05)\end{array}$ & $\begin{array}{l}-0.1947 * * * \\
\quad(-6.23)\end{array}$ & $\begin{array}{c}-0.1840 * * * \\
(-6.76)\end{array}$ & $\begin{array}{l}-0.2215^{* * *} \\
\quad(-5.90)\end{array}$ & $\begin{array}{c}-0.1737 * * * \\
(-5.40)\end{array}$ & $\begin{array}{l}-0.2549 * * * \\
\quad(-6.82)\end{array}$ & $\begin{aligned} & -0.1868 * * * \\
& (-5.94)\end{aligned}$ \\
\hline $\begin{array}{l}\text { RBC-Related Measure } \\
\text { *Bond Worse-Rated (q-1) }\end{array}$ & $\begin{array}{l}0.0099 \\
(1.20)\end{array}$ & $\begin{array}{l}0.0096 \\
(1.35)\end{array}$ & $\begin{array}{c}-0.0042^{* * *} \\
\quad(-6.18)\end{array}$ & $\begin{array}{c}-0.0040 * * * \\
(-7.06)\end{array}$ & $\begin{array}{l}0.0005 \\
(0.80)\end{array}$ & $\begin{array}{l}0.0001 \\
(0.18)\end{array}$ & $\begin{array}{c}-0.0003^{* * *} \\
(-8.36)\end{array}$ & $\begin{aligned}-0.0001 * * * \\
\\
(-6.24)\end{aligned}$ \\
\hline $\begin{array}{l}\text { RBC-Related Measure } \\
* \text { Loss (q-1)*Bond NAIC } 1 \text { Dummy (q-1) }\end{array}$ & & $\begin{array}{l}1.2236 \\
(0.98)\end{array}$ & & $\begin{array}{c}0.3423 \\
(1.26)\end{array}$ & & $\begin{array}{c}0.3882 * \\
(1.75)\end{array}$ & & $\begin{array}{c}-0.0088 \\
(-0.97)\end{array}$ \\
\hline Loss $(\mathrm{q}-1) *$ Bond NAIC 1 Dummy (q-1) & & $\begin{array}{c}0.9901^{* * *} \\
\quad(8.31)\end{array}$ & & $\begin{array}{c}0.8854^{* * *} \\
\quad(6.70)\end{array}$ & & $\begin{array}{c}0.7795^{* * *} \\
\quad(5.06)\end{array}$ & & $\begin{array}{c}1.0804 * * * \\
(7.17)\end{array}$ \\
\hline $\begin{array}{l}\text { RBC-Related Measure } \\
\text { *Bond NAIC } 1 \text { Dummy (q-1) }\end{array}$ & & $\begin{array}{c}-0.1282 * * * \\
(-3.53)\end{array}$ & & $\begin{array}{l}0.0161^{* * *} \\
\quad(6.08)\end{array}$ & & $\begin{array}{c}-0.0057 * * \\
(-2.42)\end{array}$ & & $\begin{array}{c}0.0011^{* * *} \\
(10.01)\end{array}$ \\
\hline Controls & Yes & Yes & Yes & Yes & Yes & Yes & Yes & Yes \\
\hline CUSIP-Year-Quarter FE & Yes & Yes & Yes & Yes & Yes & Yes & Yes & Yes \\
\hline Firm-Year-Quarter FE & Yes & Yes & Yes & Yes & Yes & Yes & Yes & Yes \\
\hline Cluster SE by CUSIP-Year-Quarter & Yes & Yes & Yes & Yes & Yes & Yes & Yes & Yes \\
\hline $\mathrm{N}$ & 848671 & 1418688 & 848671 & 1418688 & 848671 & 1418688 & 848671 & 1418688 \\
\hline
\end{tabular}


Panel C: Coefficient on Loss*Bond Worse-Rated of Equation (1) in Subsamples

Dependent Variable: Mrkt Value (i,j,q) $* 100$ / Cash \& Invested Assets (i,q)

NAIC Category $=1 \quad$ NAIC Category $=1 \& 2$

Coefficient on Loss (q-1)*Bond Worse-Rated (q-1)

\begin{tabular}{|c|c|c|c|c|}
\hline & $(1)$ & $(2)$ & (3) & $(4)$ \\
\hline By Insurers' Size: & $\begin{array}{c}\text { Large } \\
-0.0466 * \\
(-1.75)\end{array}$ & $\begin{array}{c}\text { Small } \\
-0.1598 * * * \\
(-6.92)\end{array}$ & $\begin{array}{c}\text { Large } \\
-0.0377 * \\
(-1.88)\end{array}$ & $\begin{array}{c}\text { Small } \\
-0.1367 * * * \\
(-6.75)\end{array}$ \\
\hline By Insurers' Rating: & $\begin{array}{c}\text { Better-Rated } \\
-0.0400 \\
(-1.60)\end{array}$ & $\begin{array}{c}\text { Worse-Rated } \\
-0.1545^{* * *} \\
(-7.08)\end{array}$ & $\begin{array}{c}\text { Better-Rated } \\
-0.0062 \\
(-0.31)\end{array}$ & $\begin{array}{c}\text { Worse-Rated } \\
-0.1386^{* * *} \\
(-7.33)\end{array}$ \\
\hline By Time Periods: & $\begin{array}{c}\text { Non-Crisis } \\
-0.1145^{* * *} \\
(-5.88)\end{array}$ & $\begin{array}{c}\text { Crisis } \\
-0.1637 * * * \\
(-3.99)\end{array}$ & $\begin{array}{c}\text { Non-Crisis } \\
-0.0982 * * * \\
(-6.20)\end{array}$ & $\begin{array}{c}\text { Crisis } \\
-0.1358 * * * \\
(-3.70)\end{array}$ \\
\hline $\begin{array}{l}\text { By RBC Ratio: } \\
\text { (cutoff is 2) }\end{array}$ & $\begin{array}{c}\text { RBC Ratio } \\
>2 \\
-0.2222 * * * \\
(-7.89)\end{array}$ & $\begin{array}{c}\text { RBC Ratio } \\
<2 \\
1.6871 \\
(0.54)\end{array}$ & $\begin{array}{c}\text { RBC Ratio } \\
>2 \\
-0.1907^{* * *} \\
(-7.78)\end{array}$ & $\begin{array}{c}\text { RBC Ratio } \\
<2 \\
2.1865 \\
(0.86)\end{array}$ \\
\hline $\begin{array}{l}\text { By RBC Ratio: } \\
\text { (cutoff is 5) }\end{array}$ & $\begin{array}{c}\text { RBC Ratio } \\
>5 \\
-0.2021^{* * *} \\
(-6.43)\end{array}$ & $\begin{array}{c}\text { RBC Ratio } \\
<5 \\
-0.3298 * * * \\
(-4.99)\end{array}$ & $\begin{array}{c}\text { RBC Ratio } \\
>5 \\
-0.1841^{* * *} \\
(-6.71)\end{array}$ & $\begin{array}{c}\text { RBC Ratio } \\
<5 \\
-0.2335 * * * \\
(-4.06)\end{array}$ \\
\hline $\begin{array}{l}\text { By RBC Ratio: } \\
\text { (cutoff is median) }\end{array}$ & $\begin{array}{c}\text { RBC Ratio } \\
>\text { Median } \\
-0.2255^{* * *} \\
(-5.88)\end{array}$ & $\begin{array}{c}\text { RBC Ratio } \\
<\text { Median } \\
-0.2401 * * * \\
(-5.72)\end{array}$ & $\begin{array}{c}\text { RBC Ratio } \\
>\text { Median } \\
-0.1899 * * * \\
(-5.71)\end{array}$ & $\begin{array}{c}\text { RBC Ratio } \\
<\text { Median } \\
-0.2147^{* * *} \\
(-5.80)\end{array}$ \\
\hline
\end{tabular}




\section{Table 5: Losses and Corporate Bond Holdings, Conditional on Purchasing NAIC 2 Category Bonds}

This table repeats Columns (1)-(4) of Table 3 conditional on the insurer purchasing any bond in the NAIC 2 category in quarter $q$. We estimate the following regression: Holding of Bond $_{i, j, q}=\alpha * \operatorname{Loss}_{i, q-1} *$ Bond Charateristics $_{j, q-1}+\beta *$ Financial $_{i, q-2} *$ Bond Charateristics $_{j, q-1}+F E_{i, q}+F E_{j, q}+e_{i, j, q}$. We only include bonds in the NAIC 1 category. Bond Characteristics include Bond Worse-Rated, coupon rate, maturity, illiquidity, and whether the bond was downgraded in $q-1$. Financial is a vector including insurers' log assets, insurers' ratings, leverage, RBC ratio, all of which are from quarter $q-2$, except RBC ratio. $\mathrm{RBC}$ ratio is only available annually, so we use the $\mathrm{RBC}$ ratio from the year prior. Controls include all the variables in Table 3. Standard errors are corrected for clustering at the bond CUSIP-year-quarter level. ***, **, and * denote statistical significance at the $1 \%, 5 \%$, and $10 \%$ levels. See Table A.1 for variable definitions.

\begin{tabular}{|c|c|c|c|c|}
\hline \multirow{3}{*}{ Dependent Variable: } & \multicolumn{4}{|c|}{ NAIC Category $=1$} \\
\hline & \multicolumn{2}{|c|}{$\begin{array}{c}\text { Mrkt Value }(\mathrm{i}, \mathrm{j}, \mathrm{q}) * 100 \\
\text { / Cash \& Invested } \\
\text { Assets (i,q) }\end{array}$} & \multicolumn{2}{|c|}{$\begin{array}{l}\text { Mrkt Value (i,j,q) *100 } \\
\text { / Mrkt Value of All } \\
\text { Corp Bonds Held }(\mathrm{i}, \mathrm{q})\end{array}$} \\
\hline & OLS & IV & OLS & IV \\
\hline & (1) & $(2)$ & (3) & (4) \\
\hline Loss $(\mathrm{q}-1) *$ Bond Worse-Rated (q-1) & $\begin{array}{c}-0.1120 * * * \\
(-4.81)\end{array}$ & $\begin{array}{c}-0.2096 * * \\
(-2.11)\end{array}$ & $\begin{array}{c}-0.3484 * * * \\
(-3.96)\end{array}$ & $\begin{array}{c}-0.7418^{*} \\
(-1.69)\end{array}$ \\
\hline Loss $(\mathrm{q}-1) *$ Bond Coupon Rate & $\begin{array}{c}0.0304^{*} \\
(1.81)\end{array}$ & $\begin{array}{c}-0.1718^{*} \\
(-1.76)\end{array}$ & $\begin{array}{c}0.1411^{* *} \\
\quad(2.18)\end{array}$ & $\begin{array}{c}0.0533 \\
(0.15)\end{array}$ \\
\hline Loss (q-1)*Bond Maturity (q) & $\begin{array}{c}-0.3144 \\
(-0.35)\end{array}$ & $\begin{array}{c}29.6083 \\
(0.55)\end{array}$ & $\begin{array}{l}0.7201 \\
(0.19)\end{array}$ & $\begin{array}{c}439.7739 \\
(0.58)\end{array}$ \\
\hline Loss (q-1)*Bond Illiquidity (q-1) & $\begin{array}{c}-0.0506 \\
(-0.64)\end{array}$ & $\begin{array}{c}1.2298 * * \\
(2.13)\end{array}$ & $\begin{array}{c}0.0255 \\
(0.09)\end{array}$ & $\begin{array}{c}3.8370 * * \\
(2.04)\end{array}$ \\
\hline Loss (q-1)*Bond Downgraded Dummy (q-1) & $\begin{array}{c}-0.1038 \\
(-1.16)\end{array}$ & $\begin{array}{c}-0.7330 \\
(-1.05)\end{array}$ & $\begin{array}{l}-0.4174 \\
(-1.22)\end{array}$ & $\begin{array}{c}-1.1345 \\
(-0.38)\end{array}$ \\
\hline Controls & Yes & Yes & Yes & Yes \\
\hline CUSIP-Year-Quarter FE & Yes & Yes & Yes & Yes \\
\hline Firm-Year-Quarter FE & Yes & Yes & Yes & Yes \\
\hline Cluster SE by CUSIP-Year-Quarter & Yes & Yes & Yes & Yes \\
\hline $\mathrm{N}$ & 505578 & 505372 & 505578 & 505372 \\
\hline
\end{tabular}


Table 6: Losses and Corporate Bond Holdings, Spline Specification

This table presents estimates of a spline specification of regressions in Columns (1) and (5) of Table 3, by splitting the Loss variable into two variables: Loss > Cutoff and Loss $<=$ Cutoff. Loss $<=$ Cutoff equals loss if Loss is not larger than the cutoff, and equals the cutoff if Loss is above the cutoff. Loss>Cutoff equals loss minus the cutoff if Loss is above the cutoff, and zero otherwise. The cutoff is the median, the $75^{\text {th }}$ percentile, or the $95^{\text {th }}$ percentile of the positive losses of each quarter. We estimate the following regressions: Holding of Bond B $_{i, j, q}=\alpha_{1} *$ Loss $>$ Cutoff $_{i, q-1} *$

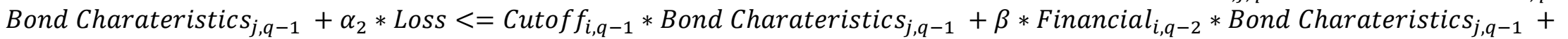
$F E_{i, q}+F E_{j, q}+e_{i, j, q}$. Bond Characteristics includes Bond Worse-Rated, coupon rate, maturity, illiquidity, whether the bond was downgraded in $q$ 1 , and a dummy variable indicating whether the bond is in the NAIC 1 category. Financial is a vector including insurers' log assets, insurers' ratings, leverage, RBC ratio, all of which are from quarter $q$-2, except RBC ratio. RBC ratio is only available annually, so we use the RBC ratio from the year prior. Controls include all the variables included in Table 3. Standard errors are corrected for clustering at the bond CUSIP-year-quarter level. $* * *, * *$, and ${ }^{*}$ denote statistical significance at the $1 \%, 5 \%$, and $10 \%$ levels. See Table A.1 for variable definitions.

\begin{tabular}{|c|c|c|c|c|c|c|}
\hline Dependent Variable: & \multicolumn{6}{|c|}{ Mrkt Value (i,j,q) *100 / Cash \& Invested Assets (i,q) } \\
\hline NAIC Category & \multicolumn{3}{|c|}{1} & \multicolumn{3}{|c|}{$1 \& 2$} \\
\hline Loss (q-1) Cutoff: & $\begin{array}{c}\text { Median } \\
(1) \\
\end{array}$ & $\begin{array}{c}75 \text { Pctl } \\
(2) \\
\end{array}$ & $\begin{array}{c}95 \text { Pctl } \\
(3) \\
\end{array}$ & $\begin{array}{c}\text { Median } \\
(4)\end{array}$ & $\begin{array}{c}75 \text { Pctl } \\
(5) \\
\end{array}$ & $\begin{array}{c}95 \text { Pctl } \\
(6) \\
\end{array}$ \\
\hline Loss $(\mathrm{q}-1)>$ Cutoff*Bond Worse-Rated $(\mathrm{q}-1)$ & $\begin{array}{c}-0.1873^{* * *} \\
(-3.76)\end{array}$ & $\begin{array}{c}-0.1564^{* *} \\
(-2.54)\end{array}$ & $\begin{array}{c}-0.0925 \\
(-0.75)\end{array}$ & $\begin{array}{c}-0.1038^{* *} \\
(-2.33)\end{array}$ & $\begin{array}{c}-0.0642 \\
(-1.16)\end{array}$ & $\begin{array}{l}0.1120 \\
(0.98)\end{array}$ \\
\hline Loss $(\mathrm{q}-1)<=$ Cutoff*Bond Worse-Rated $(\mathrm{q}-1)$ & $\begin{array}{c}-0.5511^{* * *} \\
(-3.67)\end{array}$ & $\begin{array}{c}-0.4109 * * * \\
\quad(-4.85)\end{array}$ & $\begin{array}{c}-0.2971^{* * *} \\
(-6.13)\end{array}$ & $\begin{array}{c}-0.6012^{* * *} \\
(-4.76)\end{array}$ & $\begin{array}{c}-0.4055^{* * *} \\
(-5.60)\end{array}$ & $\begin{array}{c}-0.2801^{* * *} \\
(-6.66)\end{array}$ \\
\hline Loss (q-1)>Cutoff*Bond NAIC 1 Dummy (q-1) & & & & $\begin{array}{l}0.2553 \\
(1.17)\end{array}$ & $\begin{array}{c}-0.0138 \\
(-0.05)\end{array}$ & $\begin{array}{c}-1.6020^{* * *} \\
(-2.76)\end{array}$ \\
\hline Loss $(\mathrm{q}-1)<=$ Cutoff*Bond NAIC 1 Dummy $(\mathrm{q}-1)$ & & & & $\begin{array}{c}3.8381 * * * \\
(6.51)\end{array}$ & $\begin{array}{c}2.4188 * * * \\
\quad(7.16)\end{array}$ & $\begin{array}{c}1.6317 * * * \\
(8.23)\end{array}$ \\
\hline Controls & Yes & Yes & Yes & Yes & Yes & Yes \\
\hline CUSIP-Year-Quarter FE & Yes & Yes & Yes & Yes & Yes & Yes \\
\hline Firm-Year-Quarter FE & Yes & Yes & Yes & Yes & Yes & Yes \\
\hline Cluster SE by CUSIP-Year-Quarter & Yes & Yes & Yes & Yes & Yes & Yes \\
\hline $\mathrm{N}$ & 848671 & 848671 & 848671 & 1418688 & 1418688 & 1418688 \\
\hline
\end{tabular}




\section{Table 7: Losses and Corporate Bond Purchases \& Disposals}

In Panel A, Columns (1) and (2), the dependent variable is insurer $i$ 's actual costs for buying bond $j$ in quarter $q$, divided by insurer $i$ 's cash and invested assets, then multiplied by 100,000. The dependent variable is zero for insurers that do not buy the bond. We include all the corporate bonds that an insurer can theoretically buy - any corporate bond any P\&C insurer bought in quarter $q$. We exclude insurer-quarter observations, for which the insurer does not acquire a single bond (including government bond and other fixed-income securities). These observations are likely due to institutional frictions that prevent insurers from selling any bonds in a certain quarter (e.g., the insurer may decide to wait until the end of the year to buy bonds after they see the entire year's financial performance). In Columns (3) and (4) of Panel A, the dependent variable is the par value of bond $j$ insurer $i$ sold in quarter $q$, as a percentage of the par value of bond $j$ insurer $i$ held at the end of quarter $q$-2. Controls include interaction terms between each of insurers' financials (assets, rating, leverage, and RBC ratio) and bond characteristics, i.e., all the variables included in Table 3. Standard errors are corrected for clustering at the bond CUSIP-year-quarter level. ***, **, and * denote statistical significance at the 1\%, 5\%, and 10\% levels. See Table A.1 for variable definitions. In Panels B and C, we present summary statistics on the buying and selling of corporate bonds by insurers that experience losses in the prior quarter and those that do not. In Panel $\mathrm{B}$, for each bond that is acquired by any P\&C insurer in quarter q, we calculate the average purchase (actual costs divided by insurers' cash and invested assets then multiplied by 100,000, zero for insurers that do not buy the bond) for two subsamples: insurers that suffer losses in $q-1$ and insurers that did not. Thus, each bond-quarter observation has two averages. Then we group bonds into different groups and calculate the mean (median) of the bond-quarter level average purchases for insurers with and without losses. A bond is put in the following groups in quarter $q$ based on its NAIC designation and rating in quarter $q-1$. Bonds in the NAIC 1 category are sorted into safer (included in Column (1)) and riskier (included in Column (2)) groups based on their ratings with the median as the cutoff. Similarly, bonds in the NAIC 2 category are sorted by rating into safer (included in Column (3)) and riskier (included in Column (4)) groups. Bonds in the NAIC 3-6 categories are included in Column (5). Therefore, from Column (1) to Column (5), bonds become riskier. We also sort bonds based on their illiquidity, measured by the percentage of zero trading days in quarter $q$ - 1 , using the median as the cutoff. More liquid bonds are included in Column (6). More illiquid bonds are included in Column (7). In Panel B, Row a (b) tabulates the mean of the bond-quarter average purchases among insurers with (without) losses in $q-1$. Row c tabulates the difference between Rows a and b. Row d tabulates the difference (Row c) as a percentage of Row b, the mean across bonds of the average purchase among insurers without losses. Rows e-h repeat Rows a-d replacing the mean with the median of the bond-quarter average purchase. Row i tabulates the correlation of bond-quarter average purchase among insurers with losses and the average among those without losses in $q-1$. In Panel C, we conduct a similar exercise with insurers' disposal of bonds. For each bond held by any insurer in quarter $q$, we calculate the insurer-bond-quarter $(i, j, q)$ level disposal as the par value of bond $j$ insurer $i$ sold in quarter $q$ in percentages of the par value of bond $j$ insurer $i$ held at the end of quarter $q-2$, and zero if no sale was made. We then take the average disposal for each bond-quarter of the two subsamples of insurers: those with losses in $q-1$ and those without losses in $q-1$. Similar to Panel B, we sort bonds into different categories, using the median in this sample as cutoffs for safer vs. riskier and more liquid vs. more illiquid. We tabulate the mean (and 90th percentile) of the average sales in the two subsamples of insurers, as well as the difference between the two. We report the 90th percentile in Rows e-f instead of the median, because the median (and even 75th percentile) of the average sales is often zero. 
Panel A: Losses, and Corporate Bond Purchase/Disposal, Regression Estimates

\begin{tabular}{|c|c|c|c|c|}
\hline \multirow{4}{*}{ Dependent Var } & \multicolumn{2}{|c|}{ Acquisition } & \multicolumn{2}{|c|}{ Disposal } \\
\hline & \multicolumn{2}{|c|}{$\begin{array}{l}\text { Actual Costs*10E5 / Cash } \\
\text { \& Invested Assets (i,j,g) }\end{array}$} & \multicolumn{2}{|c|}{ \% of Par Value Sold (i,j,q) } \\
\hline & 1 & $1 \& 2$ & 1 & $1 \& 2$ \\
\hline & (3) & (4) & (3) & (4) \\
\hline Loss (q-1)*Bond Worse-Rated (q-1) & $\begin{array}{c}-2.4386 * * \\
(-2.48)\end{array}$ & $\begin{array}{c}-1.8262 * * \\
(-2.34)\end{array}$ & $\begin{array}{l}0.0020 \\
(1.14)\end{array}$ & $\begin{array}{l}0.0023 \\
(1.40)\end{array}$ \\
\hline Loss $(\mathrm{q}-1) *$ Bond Coupon Rate & $\begin{array}{c}-0.1543 \\
(-0.30)\end{array}$ & $\begin{array}{l}-0.3370 \\
(-0.97)\end{array}$ & $\begin{array}{l}0.0026 \\
(1.28)\end{array}$ & $\begin{array}{l}0.0011 \\
(0.69)\end{array}$ \\
\hline Loss (q-1)*Bond Maturity (q) & $\begin{array}{c}2.3106 * * \\
(2.21)\end{array}$ & $\begin{array}{l}-4.5742 \\
(-1.17)\end{array}$ & $\begin{array}{l}0.0015 \\
(0.00)\end{array}$ & $\begin{array}{c}-0.5878 \\
(-1.15)\end{array}$ \\
\hline Loss $(\mathrm{q}-1) *$ Bond Illiquidity $(\mathrm{q}-1)$ & $\begin{array}{c}-0.0866 * * \\
(-2.52)\end{array}$ & $\begin{array}{c}-0.0898 * * * \\
(-3.96)\end{array}$ & $\begin{array}{l}0.0001 \\
(0.69)\end{array}$ & $\begin{array}{l}0.0001 \\
(0.89)\end{array}$ \\
\hline Loss (q-1)*Bond Downgraded Dummy (q-1) & $\begin{array}{l}6.4897 \\
(1.47)\end{array}$ & $\begin{array}{c}6.2845^{*} \\
(1.92)\end{array}$ & $\begin{array}{l}0.0107 \\
(1.20)\end{array}$ & $\begin{array}{l}-0.0053 \\
(-0.72)\end{array}$ \\
\hline Loss (q-1)*Bond NAIC 1 Dummy (q-1) & & $\begin{array}{c}9.3325 * * * \\
(2.71)\end{array}$ & & $\begin{array}{l}-0.0082 \\
(-0.99)\end{array}$ \\
\hline Log Assets (q-2)*Bond Worse-Rated (q-1) & $\begin{array}{c}0.0093^{*} \\
(1.84)\end{array}$ & $\begin{array}{c}0.0139 * * * \\
(3.49)\end{array}$ & $\begin{array}{l}-0.0087 \\
(-0.72)\end{array}$ & $\begin{array}{l}-0.0056 \\
(-0.53)\end{array}$ \\
\hline Log Assets (q-2)*Bond Coupon Rate & $\begin{array}{c}-0.0010 \\
(-0.32)\end{array}$ & $\begin{array}{l}-0.0009 \\
(-0.41)\end{array}$ & $\begin{array}{c}-0.0655 * * * \\
(-4.98)\end{array}$ & $\begin{array}{c}-0.0613^{* * *} \\
(-5.92)\end{array}$ \\
\hline Log Assets (q-2)*Bond Maturity (q) & $\begin{array}{c}0.0454^{* *} \\
(2.57)\end{array}$ & $\begin{array}{c}0.0381 * * * \\
(2.66)\end{array}$ & $\begin{array}{l}11.6512^{* * *} \\
(2.77)\end{array}$ & $\begin{array}{c}12.7424^{* * *} \\
\quad(3.93)\end{array}$ \\
\hline Log Assets (q-2)*Bond Illiquidity (q-1) & $\begin{array}{c}0.0031^{* * *} \\
(15.15)\end{array}$ & $\begin{array}{c}0.0024 * * * \\
(18.96)\end{array}$ & $\begin{array}{c}-0.0009 * \\
(-1.70)\end{array}$ & $\begin{array}{c}-0.0009 * * \\
(-2.00)\end{array}$ \\
\hline Log Assets (q-2)*Bond Downgraded Dummy (q-1) & $\begin{array}{l}0.0147 \\
(0.60)\end{array}$ & $\begin{array}{l}0.0062 \\
(0.37)\end{array}$ & $\begin{array}{c}0.1270^{*} \\
(1.79)\end{array}$ & $\begin{array}{l}0.0682 \\
(1.22)\end{array}$ \\
\hline Log Assets (q-2)*Bond NAIC 1 Dummy (q-1) & & $\begin{array}{c}-0.1614^{* * *} \\
(-9.09)\end{array}$ & & $\begin{array}{l}0.0766 \\
(1.41)\end{array}$ \\
\hline $\begin{array}{l}\text { Insurer Rating (larger=worse) (q-2) } \\
\quad * \text { Bond Worse-Rated (q-1) }\end{array}$ & $\begin{array}{l}0.0016 \\
(0.30)\end{array}$ & $\begin{array}{l}0.0016 \\
(0.38)\end{array}$ & $\begin{array}{c}0.0287^{*} \\
(1.94)\end{array}$ & $\begin{array}{c}0.0273^{* *} \\
(1.97)\end{array}$ \\
\hline Insurer Rating (q-2)*Bond Coupon Rate & $\begin{array}{c}-0.0030 \\
(-0.83)\end{array}$ & $\begin{array}{c}0.0028 \\
(1.16)\end{array}$ & $\begin{array}{c}0.0297 * \\
(1.71)\end{array}$ & $\begin{array}{l}0.0092 \\
(0.68)\end{array}$ \\
\hline Insurer Rating (q-2)*Bond Maturity (q) & $\begin{array}{c}-0.0249 * \\
(-1.89)\end{array}$ & $\begin{array}{l}0.0422 \\
(1.00)\end{array}$ & $\begin{array}{l}23.6296 * * * \\
(3.98)\end{array}$ & $\begin{array}{l}20.1346^{* * *} \\
\quad(4.05)\end{array}$ \\
\hline Insurer Rating (q-2)*Bond Illiquidity (q-1) & $\begin{array}{c}-0.0016^{* * *} \\
(-8.15)\end{array}$ & $\begin{array}{c}-0.0014^{* * *} \\
(-10.38)\end{array}$ & $\begin{array}{c}-0.0015^{* *} \\
(-2.02)\end{array}$ & $\begin{array}{l}-0.0025^{* * *} \\
(-3.76)\end{array}$ \\
\hline Insurer Rating (q-2)*Bond Downgraded Dummy (q-1 & $\begin{array}{c}-0.0174 \\
(-0.86)\end{array}$ & $\begin{array}{l}0.0131 \\
(0.82)\end{array}$ & $\begin{array}{l}0.0913 \\
(0.76)\end{array}$ & $\begin{array}{c}0.0389 \\
(0.42)\end{array}$ \\
\hline Insurer Rating (q-2)*Bond NAIC 1 Dummy (q-1) & & $\begin{array}{l}-0.0100 \\
(-0.55)\end{array}$ & & $\begin{array}{c}-0.1599 * * \\
(-2.11)\end{array}$ \\
\hline Controls & Yes & Yes & Yes & Yes \\
\hline CUSIP-Year-Quarter FE & Yes & Yes & Yes & Yes \\
\hline Firm-Year-Quarter FE & Yes & Yes & Yes & Yes \\
\hline Cluster SE by CUSIP-Year-Quarter & Yes & Yes & Yes & Yes \\
\hline $\mathrm{N}$ & 17457838 & 34467944 & 819578 & 1366253 \\
\hline
\end{tabular}


Panel B: Mean and Median of Average Purchase for Insurers with and without Losses

\begin{tabular}{|c|c|c|c|c|c|c|c|}
\hline & \multicolumn{2}{|c|}{ NAIC 1} & \multicolumn{2}{|c|}{ NAIC 2} & \multirow{2}{*}{$\begin{array}{c}\text { NAIC 3-6 } \\
(5) \\
\end{array}$} & \multirow{2}{*}{$\begin{array}{c}\text { More } \\
\text { Liquid } \\
(6)\end{array}$} & \multirow{2}{*}{$\begin{array}{c}\text { More } \\
\text { Illiquid } \\
(7)\end{array}$} \\
\hline & $\begin{array}{l}\text { Safer } \\
\text { (1) }\end{array}$ & $\begin{array}{l}\text { Riskier } \\
\text { (2) }\end{array}$ & $\begin{array}{l}\text { Safer } \\
\text { (3) }\end{array}$ & $\begin{array}{c}\text { Riskier } \\
\text { (4) }\end{array}$ & & & \\
\hline & \multicolumn{7}{|c|}{ Mean } \\
\hline a. Loss $>0$ & 2.151 & 1.704 & 0.963 & 0.856 & 0.162 & 1.160 & 0.989 \\
\hline b. Loss $=0$ & 1.873 & 1.529 & 0.928 & 0.867 & 0.170 & 1.017 & 0.949 \\
\hline c. a minus b & 0.278 & 0.175 & 0.035 & -0.011 & -0.008 & 0.143 & 0.040 \\
\hline \multirow[t]{2}{*}{ d. c as $\%$ of b } & 14.842 & 11.445 & 3.772 & -1.269 & -4.706 & 14.061 & 4.215 \\
\hline & \multicolumn{7}{|c|}{ Median } \\
\hline e. Loss $>0$ & 0.545 & 0.420 & 0.168 & 0.112 & 0.009 & 0.131 & 0.043 \\
\hline f. Loss $=0$ & 0.390 & 0.320 & 0.184 & 0.159 & 0.019 & 0.132 & 0.059 \\
\hline g. $a$ minus $b$ & 0.155 & 0.100 & -0.016 & -0.047 & -0.010 & -0.001 & -0.016 \\
\hline \multirow[t]{2}{*}{ h. c as $\%$ of b } & 39.744 & 31.250 & -8.696 & -29.560 & -52.632 & -0.758 & -27.119 \\
\hline & \multicolumn{7}{|c|}{ Correlation between Row a \& b } \\
\hline i. $\rho(a, b)$ & 0.734 & 0.670 & 0.498 & 0.433 & 0.274 & 0.614 & 0.728 \\
\hline
\end{tabular}

Panel C: Mean and 90th Percentile of Average Disposal for Insurers with and without Losses

\begin{tabular}{|c|c|c|c|c|c|c|c|}
\hline & \multicolumn{2}{|c|}{ NAIC 1} & \multicolumn{2}{|c|}{ NAIC 2} & \multirow[b]{2}{*}{$\begin{array}{c}\text { NAIC 3-6 } \\
(5) \\
\end{array}$} & \multirow{2}{*}{$\begin{array}{c}\text { More } \\
\text { Liquid } \\
(6)\end{array}$} & \multirow{2}{*}{$\begin{array}{c}\text { More } \\
\text { Illiquid } \\
(7)\end{array}$} \\
\hline & $\begin{array}{l}\text { Safer } \\
(1)\end{array}$ & $\begin{array}{c}\text { Riskier } \\
(2)\end{array}$ & $\begin{array}{l}\text { Safer } \\
(3)\end{array}$ & $\begin{array}{c}\text { Riskier } \\
(4)\end{array}$ & & & \\
\hline & \multicolumn{7}{|c|}{ Mean } \\
\hline a. Loss $>0$ & 5.811 & 5.139 & 5.519 & 6.091 & 12.823 & 8.547 & 7.669 \\
\hline b. Loss $=0$ & 5.424 & 4.850 & 5.283 & 5.830 & 11.245 & 8.098 & 6.833 \\
\hline c. a minus b & 0.387 & 0.289 & 0.236 & 0.261 & 1.578 & 0.449 & 0.836 \\
\hline \multirow[t]{2}{*}{ d. c as \% of b } & 7.135 & 5.959 & 4.467 & 4.477 & 14.033 & 5.545 & 12.235 \\
\hline & \multicolumn{7}{|c|}{ 90th Percentile } \\
\hline e. Loss $>0$ & 14.815 & 13.333 & 16.667 & 19.231 & 50.000 & 25.000 & 16.667 \\
\hline f. Loss $=0$ & 13.105 & 11.765 & 13.961 & 16.667 & 40.000 & 23.133 & 12.590 \\
\hline g. $a$ minus $b$ & 1.710 & 1.568 & 2.706 & 2.564 & 10.000 & 1.867 & 4.077 \\
\hline \multirow[t]{2}{*}{ h. c as $\%$ of b } & 13.048 & 13.328 & 19.383 & 15.384 & 25.000 & 8.071 & 32.383 \\
\hline & \multicolumn{7}{|c|}{ Correlation between Row a \& b } \\
\hline i. $\rho(a, b)$ & 0.170 & 0.207 & 0.212 & 0.220 & 0.138 & 0.284 & 0.130 \\
\hline
\end{tabular}




\section{Appendix}

\section{Table A.1: Variable Definitions}

\section{Firm-Level Financial Variables}

\begin{tabular}{|c|c|}
\hline Assets & Net admitted assets \\
\hline Leverage & Total liabilities/net admitted assets \\
\hline $\mathrm{RBC}$ ratio & See Section 2 \\
\hline Insurer Rating & $\begin{array}{l}\text { Rating from A.M. Best, converted to a numeric value, larger means worse rating. } 1 \\
\text { for A.M. Best rating of } \mathrm{A}++, 2 \text { for } \mathrm{A}+, 3 \text { for } \mathrm{A}, 4 \text { for } \mathrm{A}-,, 5 \text { for } \mathrm{B}++, 6 \text { for } \mathrm{B}+, 7 \text { for } \\
\mathrm{B}, 8 \text { for } \mathrm{B}-,, 9 \text { for } \mathrm{C}++, 10 \text { for } \mathrm{C}+, 11 \text { for } \mathrm{C}, 12 \text { for } \mathrm{C}-\text {, etc. }\end{array}$ \\
\hline Net Income & Net income scaled by assets \\
\hline $\begin{array}{l}\text { Direct Premium } \\
\text { Written }\end{array}$ & Direct premium written scaled by assets \\
\hline Current Liquidity & $\begin{array}{l}\text { A.M. Best's measure of insurers' liquidity, which "measures the proportion of } \\
\text { liabilities (excluding AVR, conditional reserves, and separate account liabilities) } \\
\text { covered by cash and unaffiliated holdings, excluding mortgages and real estate”. }\end{array}$ \\
\hline Asset Grth & $\begin{array}{l}\text { The admitted assets of the life insurer in year }(\mathrm{t}-1) \text { minus that in year }(\mathrm{t}-2) \text {, } \\
\text { scaled by the latter, in percentage }\end{array}$ \\
\hline Loss & $\begin{array}{l}\text { Set to zero if net underwriting gain is positive. Equal to the negative of net } \\
\text { underwriting gain, scaled by lagged assets, if net underwriting gain is negative. Net } \\
\text { underwriting gain is available on Statement of Income in the statutory filings, Line } \\
8 \text { Column } 1 \text { in } 2014 \text { filing. To break it down, P\&C Losses = (losses incurred + loss } \\
\text { expenses incurred + other underwriting expenses incurred + aggregate write-ins for } \\
\text { underwriting deductions) - (premiums earned + net income of protected cells), and } \\
\text { set to } 0 \text { if the first bracket is smaller than the second bracket. Life insurers } \\
\text { unaffiliated with P\&C insurers, when included in regressions, are assigned P\&C } \\
\text { Losses equal to zero. Losses incurred = losses paid less salvage from direct } \\
\text { business and reinsurance assumed - reinsurance recovered + net losses unpaid } \\
\text { current year - net losses unpaid prior year }\end{array}$ \\
\hline Gain & $\begin{array}{l}\text { Net underwriting gain scaled by lagged assets if net underwriting gain is positive, } \\
\text { and zero otherwise }\end{array}$ \\
\hline $\begin{array}{l}\text { P\&C Weather } \\
\text { Exposure }\end{array}$ & $\begin{array}{l}\text { Instrument variable for P\&C Loss, see Section } 3 \text { for the construction of the } \\
\text { variable }\end{array}$ \\
\hline Cash & $\begin{array}{l}\text { From Summary Investment Schedule, Line 10, which includes cash, cash- } \\
\text { equivalents (Schedule E Part 2), and short-term investments (Schedule DA Part } 1 \\
\text { investments with one-year or less maturity at the time of acquisition including } \\
\text { exempt money market funds and class one money market mutual funds). }\end{array}$ \\
\hline
\end{tabular}




\section{CUSIP-Level Bond Variables}

\begin{tabular}{ll}
\hline Bond Rating & $\begin{array}{l}\text { We first convert bond ratings to numeric values (see Table A.2) and take the } \\
\text { average of the ratings across rating agencies }\end{array}$ \\
\hline Bond Worse-Rated & $\begin{array}{l}\text { We transform different rating agencies' latest bond ratings to numeric values and } \\
\text { take the average across different rating agencies. For bonds in the NAIC 1 } \\
\text { category, Bond Worse-Rated is } 1 \text { for bonds rated AAA, and increases to } 7 \text { for } \\
\text { bonds rated A- (see Table A.2 in Appendix) }\end{array}$ \\
\hline Bond Maturity & Number of years until the bond matures divided by 1000 \\
\hline Coupon Rate & As reported by the insurers in the regulatory filings \\
\hline Downgraded Dummy & $\begin{array}{l}\text { Dummy variable that equals one if the bond has been downgraded in a time period } \\
\text { by any rating agency }\end{array}$ \\
\hline Bond Illiquidity & $\begin{array}{l}\text { 0-Trading Day, which is the fraction (or percentage if specified so in the table) of } \\
\text { days when no trading for this bond happened relative to the number of trading } \\
\text { days; imputed round-trip costs in a robustness test in Table A.6 }\end{array}$ \\
\hline NAIC 1 Dummy & $\begin{array}{l}\text { Dummy variable that equals one if the bond belongs to NAIC } 1 \text { category (when } \\
\text { insurers report different NAIC designations for the same bond in the same quarter, } \\
\text { we take the riskiest NAIC category, as it is likely the most truthful designation } \\
\text { since insurers are unlikely to manipulate bonds' NAIC designation to a riskier one) }\end{array}$ \\
\hline
\end{tabular}

Table A.2: Conversion from Bond Rating to Numeric Value

We transform bond ratings to numeric values and take the average across different rating agencies. This table shows how we convert the mean rating to the variable Worse-Rated, which can also be not an integer.

\begin{tabular}{|c|c|c|}
\hline NAIC Category & Bond Rating & Worse-Rated \\
\hline \multirow{4}{*}{1} & AAA & 1 \\
\cline { 2 - 3 } & AA+ & 2 \\
\cline { 2 - 3 } & AA & 3 \\
\cline { 2 - 3 } & AA- & 4 \\
\cline { 2 - 3 } & A+ & 5 \\
\cline { 2 - 3 } & A & 6 \\
\hline \multirow{4}{*}{2} & A- & 7 \\
\hline & BBB + & 1 \\
\cline { 2 - 3 } & BBB & 2 \\
\hline
\end{tabular}




\section{Table A.3: How Insurers' Size Correlates with Cash Flow Volatility and Ratings}

In Panel A, the dependent variable is insurers' five-year operating cash flow volatility from year $y$-4 to year $y$, and the independent are from year $y$-5. Columns (1)-(2) use P\&C insurers, (3)-(4) life insurers. All columns include year fixed effects. Columns (2) and (4) also include firm fixed effects. In Panel B, the dependent variable is insurers' ratings in year $y$. The table estimates how insurers' ratings are related to their lagged financial variables. Columns (1)-(3) use P\&C insurers, (4)-(6) life insurers. All columns include year fixed effects. Columns (3) and (5) also include firm fixed effects. Standard errors are corrected for clustering at the insurer level. ***, **, and * denote statistical significance at the $1 \%, 5 \%$, and $10 \%$ levels. See Table A.1 for variable definitions.

Panel A: Insurers' Size and Operating Cash Flow Volatility

\begin{tabular}{|c|c|c|c|c|}
\hline \multirow[t]{3}{*}{ Dependent Var: } & \multicolumn{4}{|c|}{ Oprt Income Vol (y-4 to y) } \\
\hline & \multicolumn{2}{|c|}{ P\&C Insurers } & \multicolumn{2}{|c|}{ Life Insurers } \\
\hline & (1) & $(2)$ & (3) & (4) \\
\hline Log(Assets) (y-5) & $\begin{array}{c}-0.5274 * * * \\
(-12.98)\end{array}$ & $\begin{array}{c}-0.1468 * * * \\
(-2.58)\end{array}$ & $\begin{array}{c}-0.4815^{* * *} \\
(-7.15)\end{array}$ & $\begin{array}{c}-0.1200 \\
(-0.85)\end{array}$ \\
\hline Leverage (y-5) & $\begin{array}{c}0.3513^{* * *} \\
\quad(3.30)\end{array}$ & $\begin{array}{c}0.0813^{* * *} \\
\quad(2.67)\end{array}$ & $\begin{array}{c}-3.9794 * * * \\
(-4.41)\end{array}$ & $\begin{array}{c}0.4183 \\
(0.95)\end{array}$ \\
\hline RBC Ratio (y-5) & $\begin{array}{c}-0.0132 * * * \\
(-4.94)\end{array}$ & $\begin{array}{c}-0.0034^{* * *} \\
(-3.19)\end{array}$ & $\begin{array}{c}-0.0018 * * \\
(-2.44)\end{array}$ & $\begin{array}{c}-0.0005^{*} \\
(-1.78)\end{array}$ \\
\hline Firm FE & & Yes & & Yes \\
\hline Year FE & Yes & Yes & Yes & Yes \\
\hline Cluster SE by Firm & Yes & Yes & Yes & Yes \\
\hline $\mathrm{N}$ & 21333 & 21333 & 12989 & 12989 \\
\hline
\end{tabular}


Panel B: Insurers' Size and Financial Strength Ratings

\begin{tabular}{|c|c|c|c|c|c|c|}
\hline \multirow[t]{3}{*}{ Dependent Variable: } & \multicolumn{6}{|c|}{ Insurers' Rating (y) (Larger Number = Worse Rating) } \\
\hline & \multicolumn{3}{|c|}{ P\&C Insurer } & \multicolumn{3}{|c|}{ Life Insurer } \\
\hline & $(1)$ & $(2)$ & (3) & (4) & (5) & (6) \\
\hline log(Assets) (y-1) & & $\begin{array}{c}-0.52 * * * \\
(-9.37)\end{array}$ & $\begin{array}{c}-0.36 * * * \\
(-3.87)\end{array}$ & & $\begin{array}{c}-0.68 * * * \\
(-15.62)\end{array}$ & $\begin{array}{c}-0.30 * * * \\
(-2.88)\end{array}$ \\
\hline Leverage (y-1) & $\begin{array}{c}0.56 \\
(1.50)\end{array}$ & $\begin{array}{c}1.19 * * * \\
(3.23)\end{array}$ & $\begin{array}{c}0.33^{* *} \\
(2.28)\end{array}$ & $\begin{array}{l}-1.04^{*} \\
(-1.89)\end{array}$ & $\begin{array}{l}0.69 * \\
(1.84)\end{array}$ & $\begin{array}{l}0.76^{* *} \\
(2.26)\end{array}$ \\
\hline RBC Ratio (y-1) & $\begin{array}{c}-0.005^{* *} \\
(-2.56)\end{array}$ & $\begin{array}{c}-0.004 * * \\
(-2.53)\end{array}$ & $\begin{array}{c}-0.002 * * \\
(-2.12)\end{array}$ & $\begin{array}{l}0.002 \\
(1.59)\end{array}$ & $\begin{array}{l}0.002 \\
(1.42)\end{array}$ & $\begin{array}{c}0.001^{* *} \\
(2.47)\end{array}$ \\
\hline Direct Premium Written (y-1) & $\begin{array}{c}-0.01 \\
(-0.30)\end{array}$ & $\begin{array}{c}-0.17 * * * \\
(-3.92)\end{array}$ & $\begin{array}{c}-0.01 \\
(-0.61)\end{array}$ & $\begin{array}{c}0.38 * * * \\
(6.58)\end{array}$ & $\begin{array}{c}0.24 * * * \\
(5.17)\end{array}$ & $\begin{array}{c}0.09 * * * \\
(2.65)\end{array}$ \\
\hline Net Income (y-1) & $\begin{array}{c}-5.48 * * * \\
(-3.96)\end{array}$ & $\begin{array}{c}-4.17 * * * \\
(-3.68)\end{array}$ & $\begin{array}{l}-0.80 * \\
(-1.72)\end{array}$ & $\begin{array}{c}-3.43 * * * \\
(-4.47)\end{array}$ & $\begin{array}{c}-2.54 * * * \\
(-3.84)\end{array}$ & $\begin{array}{c}-0.07 \\
(-0.24)\end{array}$ \\
\hline Current Liquidity (y-1) & $\begin{array}{c}0.00 * * * \\
(3.16)\end{array}$ & $\begin{array}{c}0.00 \\
(0.51)\end{array}$ & $\begin{array}{c}0.00 \\
(0.08)\end{array}$ & $\begin{array}{c}0.00 * * \\
(2.21)\end{array}$ & $\begin{array}{c}-0.00 \\
(-1.57)\end{array}$ & $\begin{array}{c}-0.00 \\
(-0.74)\end{array}$ \\
\hline Unrealized Capital Gain (y-1) & $\begin{array}{c}-2.69 * * * \\
(-2.75)\end{array}$ & $\begin{array}{l}-1.30 * \\
(-1.77)\end{array}$ & $\begin{array}{c}-0.42 \\
(-1.49)\end{array}$ & $\begin{array}{c}-0.82 * * \\
(-2.06)\end{array}$ & $\begin{array}{c}-0.06 \\
(-0.10)\end{array}$ & $\begin{array}{c}0.55 * * * \\
(3.18)\end{array}$ \\
\hline Asset Grth (y-1) & $\begin{array}{l}0.24 * \\
(1.73)\end{array}$ & $\begin{array}{c}0.51^{* * *} \\
(3.29)\end{array}$ & $\begin{array}{c}0.14^{* *} \\
(2.36)\end{array}$ & $\begin{array}{l}-0.43^{*} \\
(-1.78)\end{array}$ & $\begin{array}{c}0.14 \\
(1.23)\end{array}$ & $\begin{array}{c}0.15 \\
(1.42)\end{array}$ \\
\hline $\begin{array}{l}\text { Year FE } \\
\text { Firm FE }\end{array}$ & Yes & Yes & $\begin{array}{l}\text { Yes } \\
\text { Yes }\end{array}$ & Yes & Yes & $\begin{array}{l}\text { Yes } \\
\text { Yes }\end{array}$ \\
\hline Cluster SE by Firm & Yes & Yes & Yes & Yes & Yes & Yes \\
\hline N (Firm-Year) & 11665 & 11665 & 11531 & 7864 & 7864 & 7756 \\
\hline Adj R2 & 0.047 & 0.172 & 0.879 & 0.162 & 0.344 & 0.915 \\
\hline
\end{tabular}


Table A.4: Insurers’ Investment Returns and Corporate Bond Portfolio Returns and Yields

In Columns (1)-(2), the dependent variable is insurers' investment income (dividends and interests) plus realized and unrealized capital gains in quarter $q$ scaled by insurers' cash and invested assets at the end of quarter $q-1$. The independent variables are insurers' lagged financial variables. Columns (1)-(2) presents results estimating the relationship between insurers' realized returns and their lagged financial variables, as in this specification: Realized Return on Cash \& Invested Assets $i_{i, q}=\beta_{1} * \log (\text { Assets })_{i, q-1}+\beta_{2} *$ Leverage $_{i, q-1}+\beta_{3} * R B C$ Ratio $_{i, y-1}+\beta_{4} *$ Insurer Rating $_{i, q-1}+F E_{q}+e_{i, q}$, where $i$ indexes the insurer, $q$ the year-quarter, and $y$ the year. In Columns (3)-(4), we replace the dependent variable with insurers' realized returns from their corporate bond portfolios. The returns are calculated as the valueweighted average of the realized returns of the corporate bonds in insurers' portfolios: the market price of the position at the end of the quarter, plus the approximated interest received during the quarter, plus any sales proceeds from selling (some of) the position during the quarter, divided by the sum of the market value at the beginning of the quarter and the actual costs spent buying additional amount during the quarter, minus one. Avg. Bond Rating is the value-weighted average of bonds' ratings in insurers' holdings. A worse rating is assigned a larger integer: e.g., AAA rated bonds are assigned 1, BBB+ rated bonds are assigned 8. Avg. 0-Trading Day is the value-weighted average of bonds' 0-trading day in insurers' holdings. Avg. Imputed Round-Trip Cost is the value-weighted average of bonds' 0-trading day in insurers' holdings divided by 1,000 . The weights for bond returns and characteristics are the mean of market value at the beginning of the quarter plus actual costs spent acquiring the bond during the quarter and the market value at end of the quarter plus considerations received from selling the bonds. As these approximated returns are highly skewed on the right, we winsorize them at the 1st and 95th percentile. In Columns (5)-(6), we replace the dependent variable with insurers' value-weighted average corporate bond portfolio yield. The weights for all bond yields and characteristics are the market value at the end of the quarter. Yields are winsorized at the 1 st and $99^{\text {th }}$ percentile. Column (1) uses life insurers. Columns (2)-(6) use P\&C insurers. Standard errors are corrected for double clustering at the insurance firm and year-quarter level. $* * *$, **, and * denote statistical significance at the $1 \%, 5 \%$, and $10 \%$ levels. See Table A.1 for variable definitions.

\begin{tabular}{|c|c|c|c|c|c|c|}
\hline \multirow{3}{*}{$\begin{array}{r}\text { Dependent Var: } \\
\text { Insurers: }\end{array}$} & \multicolumn{2}{|c|}{$\begin{array}{c}\text { Realized Return on Cash \& } \\
\text { Invested Assets (q) } \\
\end{array}$} & \multicolumn{2}{|c|}{$\begin{array}{l}\text { Corp Bond Portfolio } \\
\text { Realized Return (q) }\end{array}$} & \multicolumn{2}{|c|}{$\begin{array}{c}\text { Corp Bond Portfolio } \\
\text { Yield (q) }\end{array}$} \\
\hline & Life & & & $\mathrm{P \& C}$ & & \\
\hline & $(1)$ & $(2)$ & (3) & $(4)$ & $(5)$ & $(6)$ \\
\hline Log Assets (q-1) & $\begin{array}{l}0.0264^{* * * *} \\
(4.43)\end{array}$ & $\begin{array}{l}0.0377^{* * *} \\
(8.09)\end{array}$ & $\begin{array}{l}0.2021^{* * *} \\
(3.18)\end{array}$ & $\begin{array}{l}0.1652^{* * *} \\
(3.93)\end{array}$ & $\begin{array}{c}0.0767 * \\
(1.79)\end{array}$ & $\begin{array}{l}-0.0469 \\
(-1.42)\end{array}$ \\
\hline Avg. Bond Rating (q-1) & & & & $\begin{array}{l}0.2145^{* *} \\
(2.41)\end{array}$ & & $\begin{array}{l}0.7202^{* * *} \\
\quad(7.15)\end{array}$ \\
\hline Avg. 0-Trading Day (\%) (q-1) & & & & $\begin{array}{l}-0.0103 \\
(-1.06)\end{array}$ & & $\begin{array}{c}0.0069 \\
(1.57)\end{array}$ \\
\hline Avg. Imputed Round-Trip Cost (q-1) & & & & $\begin{array}{l}0.0747 \\
(0.94)\end{array}$ & & $\begin{array}{l}0.3147^{* * *} \\
\quad(6.68)\end{array}$ \\
\hline Leverage (q-1) & $\begin{array}{l}0.5121^{* * *} \\
\quad(8.47)\end{array}$ & $\begin{array}{c}0.0360 \\
(0.97)\end{array}$ & $\begin{array}{l}-0.0018 \\
(-0.42)\end{array}$ & $\begin{array}{c}0.0001 \\
(0.03)\end{array}$ & $\begin{array}{c}-0.0088 * * \\
(-2.52)\end{array}$ & $\begin{array}{c}-0.0046^{* *} \\
(-2.38)\end{array}$ \\
\hline RBC Ratio (y-1) & $\begin{array}{r}0.0000 \\
(0.16)\end{array}$ & $\begin{array}{c}0.0004 \\
(1.48)\end{array}$ & $\begin{array}{c}-0.0024 * * \\
(-2.30)\end{array}$ & $\begin{array}{c}-0.0019 * \\
(-1.85)\end{array}$ & $\begin{array}{l}-0.0021 \\
(-1.33)\end{array}$ & $\begin{array}{l}-0.0002 \\
(-0.18)\end{array}$ \\
\hline $\begin{array}{l}\text { Insurer's Rating (q-1) } \\
\text { (larger number = worse) }\end{array}$ & $\begin{array}{c}-0.0102^{* *} \\
(-2.50)\end{array}$ & $\begin{array}{c}-0.0078 * * * \\
(-4.05)\end{array}$ & $\begin{array}{l}0.0913 * * * \\
\quad(3.12)\end{array}$ & $\begin{array}{l}0.0851^{* * *} \\
\quad(3.00)\end{array}$ & $\begin{array}{l}-0.0044 \\
(-0.17)\end{array}$ & $\begin{array}{l}-0.0102 \\
(-0.67)\end{array}$ \\
\hline Year-Quarter FE & Yes & Yes & Yes & Yes & Yes & Yes \\
\hline Cluster SE by Firm \& Year-Quarter & Yes & Yes & Yes & Yes & Yes & Yes \\
\hline $\mathrm{N}$ & 24225 & 57310 & 26937 & 26937 & 27005 & 27005 \\
\hline
\end{tabular}




\section{Table A.5: Losses and Corporate Bond Holdings, Instrumental Variable Approach, First Stage}

This table presents the first-stage results estimating Equation (1) using the instrumental variable approach, corresponding to Column (4) in Table 3. Controls include interaction terms between each of insurers' financials (assets, rating, leverage, and RBC ratio) and bond characteristics, i.e., all the independent variables used for estimation for Table 3. Standard errors are corrected for clustering at the bond CUSIP-year-quarter level. ***, **, and $*$ denote statistical significance at the $1 \%, 5 \%$, and $10 \%$ levels. See Table A.1 for variable definitions.

\begin{tabular}{|c|c|c|c|c|c|}
\hline \multirow[t]{2}{*}{ Dependent Variable: } & $\begin{array}{c}\text { Loss (q-1)*Bond Rating } \\
\text { (larger=worse) }(\mathrm{q}-1)\end{array}$ & $\begin{array}{c}\text { Loss }(\mathrm{q}-1) * \text { Bond } \\
\text { Coupon Rate }\end{array}$ & $\begin{array}{c}\text { Loss }(\mathrm{q}-1)^{*} \text { Bond } \\
\text { Months to Maturity (q) }\end{array}$ & $\begin{array}{c}\text { Loss }(\mathrm{q}-1) * \text { Bond } \\
\text { Illiquidity }(\mathrm{q}-1)\end{array}$ & $\begin{array}{c}\text { Loss }(\mathrm{q}-1) * \text { Bond } \\
\text { Downgraded Dummy }(\mathrm{q}-1)\end{array}$ \\
\hline & $(1)$ & $(2)$ & (3) & (4) & (5) \\
\hline \multirow[t]{2}{*}{ Weather Exposure (q-1)*Bond Rating (larger=worse) $(\mathrm{q}-1)$} & $0.5563 * * *$ & 0.0117 & -1.1704 & 0.0019 & -0.0021 \\
\hline & $(24.91)$ & $(1.23)$ & $(-1.64)$ & $(0.84)$ & $(-1.54)$ \\
\hline \multirow[t]{2}{*}{ Weather Exposure (q-1)*Bond Coupon Rate } & -0.0018 & $0.4468 * * *$ & 0.9749 & 0.0005 & 0.0003 \\
\hline & $(-0.17)$ & (32.16) & $(0.45)$ & $(0.24)$ & $(0.24)$ \\
\hline \multirow[t]{2}{*}{ Weather Exposure (q-1)*Bond Months to Maturity (q) } & -0.0000 & 0.0000 & 0.4695 & $-0.0000 *$ & -0.0000 \\
\hline & $(-0.84)$ & $(0.31)$ & $(0.54)$ & $(-1.75)$ & $(-0.22)$ \\
\hline \multirow[t]{2}{*}{ Weather Exposure (q-1)*Bond Illiquidity (q-1) } & 0.0717 & 0.0545 & 1.6083 & $0.5761 * * *$ & $-0.0097 *$ \\
\hline & $(1.40)$ & $(1.18)$ & $(0.21)$ & (33.46) & $(-1.88)$ \\
\hline \multirow[t]{2}{*}{ Weather Exposure (q-1)*Bond Downgraded Dummy (q-1) } & $-0.1370 *$ & -0.0213 & 1.5895 & $-0.0273 * *$ & $0.5790 * * *$ \\
\hline & $(-1.88)$ & $(-0.37)$ & $(0.33)$ & $(-2.05)$ & $(11.72)$ \\
\hline Controls & Yes & Yes & Yes & Yes & Yes \\
\hline CUSIP-Year-Quarter FE & Yes & Yes & Yes & Yes & Yes \\
\hline Firm-Year-Quarter FE & Yes & Yes & Yes & Yes & Yes \\
\hline Cluster SE by CUSIP-Year-Quarter & Yes & Yes & Yes & Yes & Yes \\
\hline $\mathrm{N}$ & 848722 & 848722 & 848722 & 848722 & 848722 \\
\hline
\end{tabular}




\section{Table A.6: Robustness Tests for Losses and Corporate Bond Holdings, Gains and Bond Holdings}

This table presents robustness results at the corporate bond-level for P\&C insurers. Panel A presents robustness results on how insurers' losses are correlated with their allocation across bonds by altering Column (5) in Panel A, Table 3. In Columns (1)-(3), we add Bond Duration as one of the characteristics of bonds. In Column (2), we omit Bond Coupon Rate and Bond Maturity. In Column (3), we use Imputed Round Trip Costs as a proxy for bond illiquidity. In Column (4), we use bonds' yield to maturity from the previous quarter as the measure for bond risk. In Columns (1)-(4), controls include interaction terms between each of insurers' financials (assets, rating, leverage, and RBC ratio) and bond characteristics, i.e., all the independent variables in Table 3. In Column (5), we repeat the original specification, replacing the insurance firm-year-quarter fixed effects with firm fixed effects and adding insurers' lagged financial variables as controls in addition to those included in Table 3. In Panel B, we repeat the OLS specifications in Table 3, replacing insurers' operating Loss with operating Gain, and present the OLS results. Gain equals net underwriting gain scaled by lagged assets if net underwriting gain is positive, and zero otherwise. The control variables include all those in Table 3. Standard errors are corrected for clustering at the bond CUSIPyear-quarter level. ***, **, and * denote statistical significance at the $1 \%, 5 \%$, and $10 \%$ levels. See Table A.1 for variable definitions.

Panel A: Losses and Corporate Bond Holdings, Robustness Tests

\begin{tabular}{|c|c|c|c|c|c|}
\hline \multirow[t]{3}{*}{ Dependent Variable: } & \multicolumn{5}{|c|}{ Mrkt Value(i,j,q)*100/Cash \& Invested Assets(i,q) } \\
\hline & \multicolumn{5}{|c|}{$1 \& 2$} \\
\hline & \multicolumn{2}{|c|}{ Including Bond Duration } & $\begin{array}{l}\text { Illiquidity = } \\
\text { Imputed } \\
\text { Round Trip } \\
\text { Costs } \\
\text { (3) }\end{array}$ & $\begin{array}{c}\text { Bond Yield } \\
\text { as Risk } \\
\text { Measure } \\
\text { (4) }\end{array}$ & $\begin{array}{l}\text { Replace Firm- } \\
\text { YrQrtr FE w/ } \\
\text { Firm FE } \\
\text { (5) }\end{array}$ \\
\hline 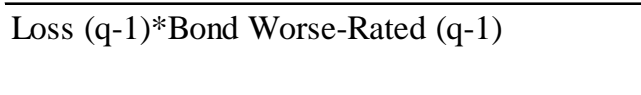 & $\begin{array}{c}-0.1455^{* * *} \\
(-6.06)\end{array}$ & $\begin{array}{c}-0.1534 * * * \\
(-6.24)\end{array}$ & $\begin{array}{c}-0.1447 * * * \\
(-6.10)\end{array}$ & & $\begin{array}{c}-0.1319 * * * \\
(-3.13)\end{array}$ \\
\hline Loss (q-1)*Bond Yield (q-1) & & & & $\begin{array}{c}0.0050 \\
(0.43)\end{array}$ & \\
\hline Loss (q-1)*Bond Duration (q-1) & $\begin{array}{c}0.0053 \\
(0.84)\end{array}$ & $\begin{array}{l}0.0029 \\
(0.46)\end{array}$ & $\begin{array}{c}0.0032 \\
(0.50)\end{array}$ & & \\
\hline Loss $(\mathrm{q}-1) *$ Bond Coupon Rate & $\begin{array}{c}-0.0457^{* * *} \\
(-2.63)\end{array}$ & & $\begin{array}{c}-0.0471^{* * *} \\
(-2.69)\end{array}$ & $\begin{array}{c}-0.0403 * * * \\
(-3.27)\end{array}$ & $\begin{array}{c}-0.0727 * * * \\
(-2.64)\end{array}$ \\
\hline Loss (q-1)*Bond Maturity (q) & $\begin{array}{l}-0.7055 \\
(-1.28)\end{array}$ & & $\begin{array}{c}-0.9774^{*} \\
(-1.74)\end{array}$ & $\begin{array}{c}-0.2024 \\
(-1.27)\end{array}$ & $\begin{array}{c}-0.3428 \\
(-0.84)\end{array}$ \\
\hline Loss (q-1)*Bond Illiquidity (q-1) & $\begin{array}{l}0.0305 \\
(0.38)\end{array}$ & $\begin{array}{l}0.0464 \\
(0.57)\end{array}$ & $\begin{array}{l}8.5013 \\
(0.86)\end{array}$ & $\begin{array}{l}-0.0859 \\
(-1.60)\end{array}$ & $\begin{array}{c}-0.2323^{*} \\
(-1.80)\end{array}$ \\
\hline Loss (q-1)*Bond Downgraded Dummy (q-1) & $\begin{array}{l}-0.1456 \\
(-1.30)\end{array}$ & $\begin{array}{l}-0.1486 \\
(-1.33)\end{array}$ & $\begin{array}{l}-0.1603 \\
(-1.44)\end{array}$ & $\begin{array}{l}-0.0888 \\
(-1.40)\end{array}$ & $\begin{array}{l}-0.0760 \\
(-0.47)\end{array}$ \\
\hline Loss (q-1)*Bond NAIC 1 Dummy (q-1) & $\begin{array}{c}0.6522 * * * \\
(5.52)\end{array}$ & $\begin{array}{c}0.7108^{* * *} \\
(5.89)\end{array}$ & $\begin{array}{c}0.6457^{* * *} \\
(5.59)\end{array}$ & $\begin{array}{l}0.0232 \\
(0.68)\end{array}$ & $\begin{array}{c}0.6538 * * * \\
(3.34)\end{array}$ \\
\hline Controls & Yes & Yes & Yes & Yes & Yes \\
\hline CUSIP-Year-Quarter FE & Yes & Yes & Yes & Yes & Yes \\
\hline Firm-Year-Quarter FE & Yes & Yes & Yes & Yes & \\
\hline Firm FE & & & & & Yes \\
\hline Cluster SE by CUSIP-Year-Quarter & Yes & Yes & Yes & Yes & Yes \\
\hline $\mathrm{N}$ & 868140 & 868233 & 863661 & 1236430 & 1342243 \\
\hline
\end{tabular}


Panel B: Gains and Corporate Bond Holdings

\begin{tabular}{|c|c|c|c|c|}
\hline \multirow{2}{*}{$\begin{array}{r}\text { Dependent Variable: } \\
\text { NAIC Category: }\end{array}$} & \multicolumn{2}{|c|}{$\begin{array}{l}\text { Mrkt Value }(\mathrm{i}, \mathrm{j}, \mathrm{q}) * 100 / \\
\text { Cash \& Invested Assets } \\
(\mathrm{i}, \mathrm{q})\end{array}$} & \multicolumn{2}{|c|}{$\begin{array}{l}\text { Mrkt Value (i,j,q) *100 / } \\
\text { Mrkt Value of All Corp } \\
\text { Bonds Held (i,q) }\end{array}$} \\
\hline & $\begin{array}{c}1 \\
(1)\end{array}$ & $\begin{array}{c}1 \& 2 \\
(2)\end{array}$ & $\begin{array}{c}1 \\
(3)\end{array}$ & $\begin{array}{c}1 \& 2 \\
(4)\end{array}$ \\
\hline Gain (q-1)*Bond Worse-Rated (q-1) & $\begin{array}{c}0.1532^{* * *} \\
(4.58)\end{array}$ & $\begin{array}{c}0.1286 * * * \\
(4.33)\end{array}$ & $\begin{array}{c}0.4161^{* *} \\
(2.50)\end{array}$ & $\begin{array}{c}0.3331^{* *} \\
(2.26)\end{array}$ \\
\hline Gain $(\mathrm{q}-1) *$ Bond Coupon Rate & $\begin{array}{c}-0.2253^{* * *} \\
(-6.61)\end{array}$ & $\begin{array}{c}-0.2005^{* * * *} \\
(-7.93)\end{array}$ & $\begin{array}{c}-1.1602 * * * \\
(-6.89)\end{array}$ & $\begin{array}{c}-0.8740 * * * \\
(-7.16)\end{array}$ \\
\hline Gain (q-1)*Bond Maturity (q) & $\begin{array}{c}-0.4734 \\
(-0.82)\end{array}$ & $\begin{array}{c}-0.4886 * * \\
(-2.08)\end{array}$ & $\begin{array}{c}-0.9952 \\
(-0.33)\end{array}$ & $\begin{array}{c}-1.5950 \\
(-0.83)\end{array}$ \\
\hline Gain (q-1)*Bond Illiquidity (q-1) & $\begin{array}{c}-0.2034 \\
(-1.37)\end{array}$ & $\begin{array}{c}-0.2681^{* *} \\
(-2.49)\end{array}$ & $\begin{array}{c}-1.5187 * * \\
(-2.16)\end{array}$ & $\begin{array}{l}-0.4847 \\
(-0.96)\end{array}$ \\
\hline Gain (q-1)*Bond Downgraded Dummy (q-1) & $\begin{array}{c}0.3661^{* * *} \\
(2.65)\end{array}$ & $\begin{array}{c}0.2536^{* *} \\
(2.31)\end{array}$ & $\begin{array}{c}1.5159 * * \\
(2.00)\end{array}$ & $\begin{array}{c}1.3706^{* *} \\
(2.40)\end{array}$ \\
\hline Gain (q-1)*Bond NAIC 1 Dummy (q-1) & & $\begin{array}{c}-0.6268 * * * \\
(-4.49)\end{array}$ & & $\begin{array}{c}-1.5116^{* *} \\
(-2.23)\end{array}$ \\
\hline Controls & Yes & Yes & Yes & Yes \\
\hline CUSIP-Year-Quarter FE & Yes & Yes & Yes & Yes \\
\hline Firm-Year-Quarter FE & Yes & Yes & Yes & Yes \\
\hline Cluster SE by CUSIP-Year-Quarter & Yes & Yes & Yes & Yes \\
\hline $\mathrm{N}$ & 848671 & 1418688 & 849175 & 1419495 \\
\hline
\end{tabular}




\section{Internet Appendix}

\section{Table IA.1: Robustness Test for Losses and Bond Holdings, Bond Characteristics from $q-2$ or $q$}

This table repeats the OLS regressions in Table 3, replacing bond characteristics with those from quarter $q$ 2 in Panel A and those from quarter $q$ in Panel B. The dependent variable is P\&C insurer $i$ 's holdings of a specific corporate bond $j$, as a percentage of $i$ 's cash and invested assets in quarter $q$ in Columns (1) and (2), or as a percentage of the total market value of all the corporate bonds insurer $i$ holds in quarter $q$ in Columns (3) and (4). We estimate the following specification: Holding of Bond Bo $_{i, q}=\alpha *$ Loss $_{i, q-1} *$ Bond Char $_{j}+\beta *$ Financial $_{i, q-2} *$ Bond Char $_{j}+F E_{i, q}+F E_{j, q}+e_{i, j, q}$. Bond Char includes Bond Worse-Rated, coupon rate, maturity, illiquidity, whether the bond was downgraded, and a dummy variable indicating whether the bond is in the NAIC 1 category. Variables in the vector, Bond Char, are from quarter $q-2$ in Panel A (other than bond maturity) and from quarter $q$ in Panel B. Financial is a vector including insurers' log assets, insurers' ratings, leverage, RBC ratio, all of which are from quarter $q-2$, except RBC ratio. RBC ratio is only available annually, so we use the $\mathrm{RBC}$ ratio from the year prior. The control variables include all those in Table 3. Standard errors are corrected for clustering at the bond CUSIP-yearquarter level. $* * *, * *$, and $*$ denote statistical significance at the $1 \%, 5 \%$, and $10 \%$ levels. See Table A.1 for variable definitions. 
Panel A: Using Bond Characteristics from Quarter q-2

\begin{tabular}{|c|c|c|c|c|}
\hline \multirow{2}{*}{$\begin{array}{r}\text { Dependent Variable: } \\
\text { NAIC Category: }\end{array}$} & \multicolumn{2}{|c|}{$\begin{array}{c}\text { Mrkt Value (i,j,q) *100 / } \\
\text { Cash \& Invested Assets } \\
(\mathrm{i}, \mathrm{q})\end{array}$} & \multicolumn{2}{|c|}{$\begin{array}{l}\text { Mrkt Value (i,j,q) *100 / } \\
\text { Mrkt Value of All Corp } \\
\text { Bonds Held (i,q) }\end{array}$} \\
\hline & $\begin{array}{c}1 \\
(1) \\
\end{array}$ & $\begin{array}{c}1 \& 2 \\
(2)\end{array}$ & $\begin{array}{c}1 \\
(3) \\
\end{array}$ & $\begin{array}{c}1 \& 2 \\
(4) \\
\end{array}$ \\
\hline Loss (q-1)*Bond Worse-Rated (q-2) & $\begin{array}{c}-0.1296^{* * *} \\
(-7.16)\end{array}$ & $\begin{array}{c}-0.1110^{* * *} \\
(-7.30)\end{array}$ & $\begin{array}{c}-0.4264 * * * \\
(-5.79)\end{array}$ & $\begin{array}{c}-0.3362 * * * \\
(-5.40)\end{array}$ \\
\hline Loss $(\mathrm{q}-1) *$ Bond Coupon Rate & $\begin{array}{c}0.0189 \\
(1.27)\end{array}$ & $\begin{array}{c}-0.0037 \\
(-0.35)\end{array}$ & $\begin{array}{c}0.1412^{* *} \\
(2.19)\end{array}$ & $\begin{array}{c}0.0301 \\
(0.66)\end{array}$ \\
\hline Loss (q-1)*Bond Maturity (q) & $\begin{array}{c}0.6066 \\
(1.43)\end{array}$ & $\begin{array}{c}-0.1277 \\
(-0.71)\end{array}$ & $\begin{array}{c}0.9866 \\
(0.40)\end{array}$ & $\begin{array}{c}-0.4162 \\
(-0.51)\end{array}$ \\
\hline Loss $(\mathrm{q}-1) *$ Bond Illiquidity $(\mathrm{q}-2)$ & $\begin{array}{c}0.0406 \\
(0.56)\end{array}$ & $\begin{array}{c}0.0402 \\
(0.77)\end{array}$ & $\begin{array}{c}0.7015^{* *} \\
\quad(2.28)\end{array}$ & $\begin{array}{c}0.5927 * * * \\
(2.66)\end{array}$ \\
\hline Loss (q-1)*Bond Downgraded Dummy (q-2) & $\begin{array}{c}0.0169 \\
(0.19)\end{array}$ & $\begin{array}{c}-0.0132 \\
(-0.21)\end{array}$ & $\begin{array}{c}0.2081 \\
(0.53)\end{array}$ & $\begin{array}{c}-0.0224 \\
(-0.08)\end{array}$ \\
\hline Loss (q-1)*Bond NAIC 1 Dummy (q-2) & & $\begin{array}{c}0.5147^{* * *} \\
\quad(6.92)\end{array}$ & & $\begin{array}{c}1.4428 * * * \\
(4.70)\end{array}$ \\
\hline Controls & Yes & Yes & Yes & Yes \\
\hline CUSIP-Year-Quarter FE & Yes & Yes & Yes & Yes \\
\hline Firm-Year-Quarter FE & Yes & Yes & Yes & Yes \\
\hline Cluster SE by CUSIP-Year-Quarter & Yes & Yes & Yes & Yes \\
\hline $\mathrm{N}$ & 812030 & 1347214 & 812506 & 1347958 \\
\hline
\end{tabular}




\section{Panel B: Using Bond Characteristics from Quarter $q$}

\begin{tabular}{|c|c|c|c|c|}
\hline \multirow{2}{*}{$\begin{array}{r}\text { Dependent Variable: } \\
\text { NAIC Category: }\end{array}$} & \multicolumn{2}{|c|}{$\begin{array}{l}\text { Mrkt Value (i,j,q) *100 / } \\
\text { Cash \& Invested Assets } \\
(\mathrm{i}, \mathrm{q})\end{array}$} & \multicolumn{2}{|c|}{$\begin{array}{l}\text { Mrkt Value (i,j,q) } * 100 \text { / } \\
\text { Mrkt Value of All Corp } \\
\text { Bonds Held (i,q) }\end{array}$} \\
\hline & $\begin{array}{c}1 \\
(1)\end{array}$ & $\begin{array}{c}1 \& 2 \\
(2)\end{array}$ & $\begin{array}{c}1 \\
(3)\end{array}$ & $\begin{array}{c}1 \& 2 \\
(4)\end{array}$ \\
\hline Loss (q-1)*Bond Worse-Rated (q) & $\begin{array}{c}-0.1254^{* * *} \\
(-7.10)\end{array}$ & $\begin{array}{c}-0.1007^{* * *} \\
(-6.84)\end{array}$ & $\begin{array}{c}-0.4485^{* * *} \\
(-6.03)\end{array}$ & $\begin{array}{c}-0.3227 * * * \\
(-5.18)\end{array}$ \\
\hline Loss (q-1)*Bond Coupon Rate & $\begin{array}{c}0.0057 \\
(0.41)\end{array}$ & $\begin{array}{c}-0.0137 \\
(-1.33)\end{array}$ & $\begin{array}{c}0.0615 \\
(1.02)\end{array}$ & $\begin{array}{c}-0.0431 \\
(-0.97)\end{array}$ \\
\hline Loss (q-1)*Bond Maturity (q) & $\begin{array}{c}1.3395 * * * \\
(2.69)\end{array}$ & $\begin{array}{c}-0.1060 \\
(-0.68)\end{array}$ & $\begin{array}{c}5.8342 \\
(1.36)\end{array}$ & $\begin{array}{c}-0.3780 \\
(-0.45)\end{array}$ \\
\hline Loss (q-1)*Bond Illiquidity (q) & $\begin{array}{c}0.0854 \\
(1.24)\end{array}$ & $\begin{array}{c}0.0463 \\
(0.91)\end{array}$ & $\begin{array}{c}0.8999 * * * \\
\quad(2.92)\end{array}$ & $\begin{array}{c}0.6413^{* * *} \\
\quad(2.85)\end{array}$ \\
\hline Loss (q-1)*Bond Downgraded Dummy (q) & $\begin{array}{c}-0.0466 \\
(-0.49)\end{array}$ & $\begin{array}{c}-0.0926 \\
(-1.33)\end{array}$ & $\begin{array}{c}-0.3296 \\
(-0.76)\end{array}$ & $\begin{array}{c}-0.4708 \\
(-1.51)\end{array}$ \\
\hline Loss (q-1)*Bond NAIC 1 Dummy (q) & & $\begin{array}{c}0.4718^{* * *} \\
\quad(6.52)\end{array}$ & & $\begin{array}{c}1.3356^{* * *} \\
(4.36)\end{array}$ \\
\hline Controls & Yes & Yes & Yes & Yes \\
\hline CUSIP-Year-Quarter FE & Yes & Yes & Yes & Yes \\
\hline Firm-Year-Quarter FE & Yes & Yes & Yes & Yes \\
\hline Cluster SE by CUSIP-Year-Quarter & Yes & Yes & Yes & Yes \\
\hline $\mathrm{N}$ & 887413 & 1487947 & 887933 & 1488774 \\
\hline
\end{tabular}

